\title{
DISTRIBUIÇÃO DE NITROGÊNIO E POTÁSSIO NA CULTURA DE MILHO (Zea mays L.) APLICADOS VIA PIVÔ CENTRAL
}

\section{DÁLCIO RICARDO BOTELHO ALVES \\ Engenheiro Agrícola}

Orientador: Prof. Dr. José Antonio Frizzone

Co-Orientador: Prof. Dr. Durval Dourado Neto

Tese apresentada à Escola Superior de Agricultura "Luiz de Queiroz", Universidade de São Paulo, para obtenção do título de Doutor em Agronomia, Área de Concentração: Irrigação e Drenagem

Piracicaba

Estado de São Paulo - Brasil

Novembro - 2000 


\section{ERRATA}

p. item

linha

onde se lê

leia-se

10

2.3 décima quinta

apresentar 4 a 8 folhas

apresentar 4 e 8 folhas

$132.4 \operatorname{sexta} \quad \mathrm{CUC}=100\left[1-\frac{\sum_{\mathrm{i}=1}^{\mathrm{n}} \mathrm{S}_{\mathrm{i}}\left|\mathrm{X}_{\mathrm{i}}-\mathrm{X}_{\mathrm{m}}\right|}{\mathrm{n} \mathrm{X}_{\mathrm{i}}}\right] \mathrm{CUC}=100\left[1-\frac{\sum_{\mathrm{i}=1}^{\mathrm{n}}\left|\mathrm{X}_{\mathrm{i}}-\mathrm{X}_{\mathrm{m}}\right|}{\mathrm{n} \mathrm{X}_{\mathrm{m}}}\right]$

$13 \quad 2.4 \quad$ décima quinta

$65 \quad 4.6 \quad$ sétima

$65 \quad 4.6 \quad$ oitava

$73 \quad 4.7 .1$ penúltima
Rezende et al., 1992

A

B

...foram afetadas...
Rezende, 1992

a

b

...não foram afetadas... 
Alves, Dálcio Ricardo Botelho

Distribuição de nitrogênio e potássio na cultura de milho (Zea mays L.) aplicados via pivô central / Dálcio Ricardo Botelho Alves. -- Piracicaba, 2000.

99 p. : il.

Tese (doutorado) - Escola Superior de Agricultura Luiz de Queiroz, 2000.

Bibliografia.

1. Adubação foliar 2. Fertimigação 3. Interceptação 4. Imigação por pivô central 5. Milho 6. Quimigação I. Título

CDD 631.7 
Aos meus pais,

\section{GERALDO E CÉLIA}

Por todo apoio, amor e incentivo

ao longo de minha vida

À minha esposa,

SÍLVIA

Que me acompanhou em todas atividades, dando força, amor e carinho

\section{DEDICO}

Aos meus irmãos, pela amizade

e convivência harmoniosa 


\section{AGRADECIMENTOS}

À Deus, pela saúde, vida e inteligência concedida, e pela sua presença permanente, especialmente, nos momentos dificeis.

À Escola Superior de Agricultura "Luiz de Queiroz" (ESALQ/USP), especialmente ao Departamento de Engenharia Rural, pela oportunidade concedida para a realização do curso de Pós-Graduação.

À Fundação de Amparo à Pesquisa do Estado de São Paulo (FAPESP), pela bolsa e apoio financeiro concedido na realização do trabalho.

Ao Prof. Dr. José Antonio Frizzone, pela amizade, contribuição, e pela objetiva orientação no desenvolvimento do trabalho.

Ao Prof. Dr. Durval Dourado Neto, pelo apoio, incentivo, amizade e valiosas sugestões e contribuições durante a fase de realização do trabalho.

Aos Professores Tarlei Arriel Botrel e Marcos Vinícius Folegatti, pelo incentivo para a realização deste curso.

Aos colegas de Pós-Graduação Fátima Conceição Rezende e Maria Del Valle Basanta, pela valiosa contribuição prestada durante toda a fase experimental deste trabalho.

Aos professores e a todos os colegas do Curso de Pós-Graduação em Irrigação e Drenagem, pela contribuição científica e proveitosas amizades.

Aos funcionários do Departamento de Engenharia Rural da ESALQ/USP, pela valiosa colaboração e amizades. 
Aos funcionários do Departamento de Produção Vegetal da ESALQ/USP, pela valiosa contribuição na fase experimental do trabalho e amizades.

Finalmente, a todos aqueles que de alguma forma contribuíram para o sucesso deste trabalho. 


\section{SUMÁRIO}

LISTA DE FIGURAS vii

LISTA DE TABELAS. $\mathrm{x}$

RESUMO xiii

SUMMARY XV

1 INTRODUÇÃO. 1

2 REVISÃO DE LITERATURA 3

2.1 Quimigação. 3

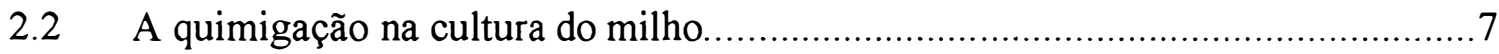

2.3 Manejo de água e adubação na cultura de milho.................................................

2.4 Uniformidade de distribuição de água em pivô central ..................................... 13

2.5 Aplicação de produtos químicos via pivô central................................................14

2.6 Efeito da cultura na distribuição de água e produtos químicos ............................17

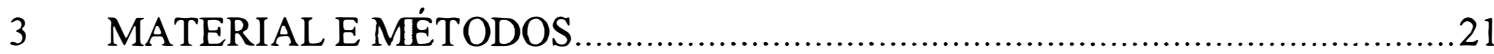

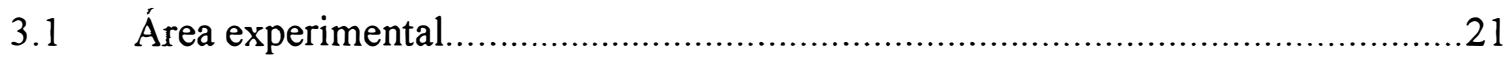

3.2 Sistema de irrigação e equipamentos para fertirrigação......................................21



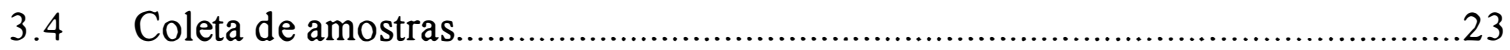

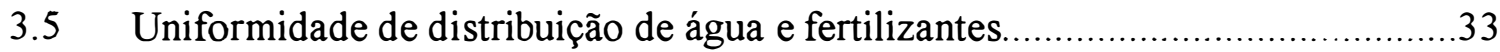

3.6 Aplicação de fertilizantes via fertirrigação na cultura do milho...........................34

3.7 Curvas de calibração de condutividade elétrica em função da

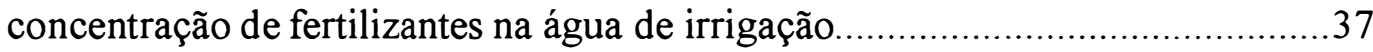

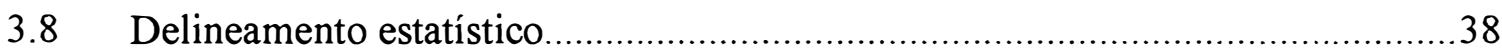

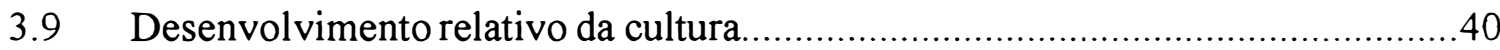

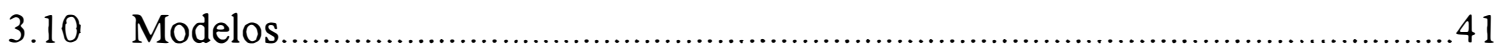


4.1 Uniformidade de distribuição de água e fertilizante............................................42

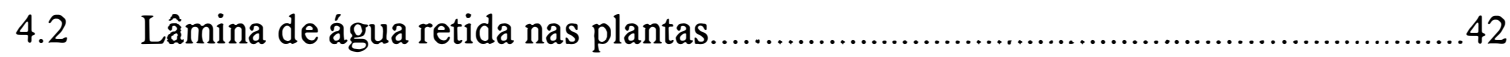

4.3 Quantidade de fertilizante interceptado pelo dossel da cultura ...........................50

4.4 Curvas ajustadas de condutividade elétrica em função da concentração de fertilizantes na água de irrigação .........................................56

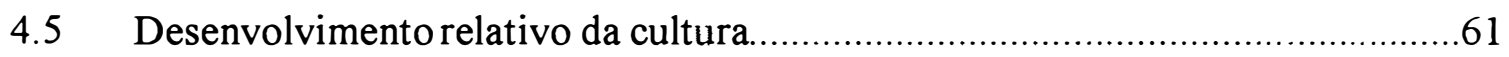

4.6 Modelos para estimativa de fertilizante interceptados pela cultura do milho.

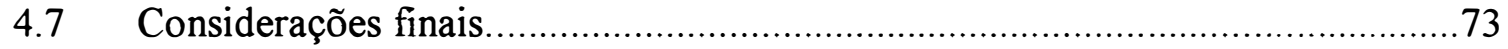



4.7.2 Considerações gerais sobre a metodologia utilizada ..........................................74

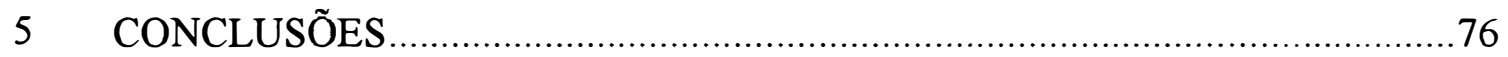

ANEXO A: VARIAÇÃO DO POTENCIAL MÁTRICO

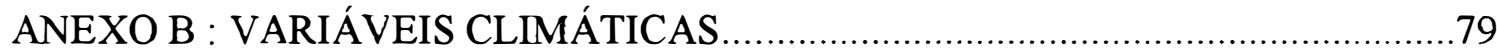

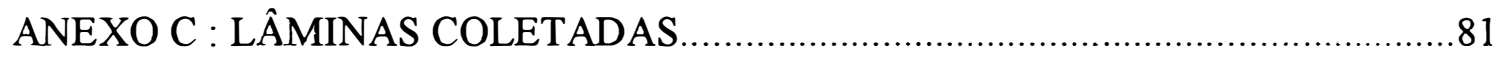

ANEXO D : CONCENTRAÇÃO E QUANTIDADES DE FERTILIZANTES...............83

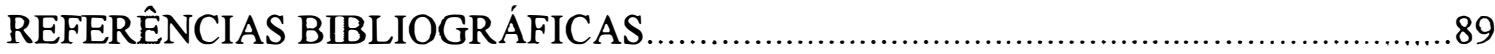




\section{LISTA DE FIGURAS}

Página

1 Localização das parcelas na área experimental .24

2 Disposição dos coletores e "piscinas" no terço inferior $(0,00 \mathrm{~m})$ da planta de milho.

3 Disposição dos coletores e "piscinas" no terço médio $(0,50 \mathrm{~m})$ da planta de milho.

4 Disposição dos coletores e "piscinas" no terço superior (1,40 m) da planta de milho.

5 Vista geral da "piscina" e coletores instalados no dossel do milho na altura de coleta de $0,00 \mathrm{~m}$ em relação ao solo.

6 Vista geral da "piscina" e coletores instalados no dossel do milho na altura de coleta de $0,50 \mathrm{~m}$ em relação ao solo

$7 \quad$ Vista geral da "piscina" e coletores instalados no dossel do milho na altura de coleta de $1,40 \mathrm{~m}$ em relação ao solo

8 Tanque e bomba injetora de fertilizantes instalados no centro do pivô

9 Perfil de precipitação ao longo da lateral do pivô com o sistema operando a $40 \%$ da velocidade máxima.

10 Curva de ajuste de vazão $\left(\mathrm{L} \mathrm{h}^{-1}\right)$ da bomba injetora de fertilizantes para diferentes regulagens do pistão $(\mathrm{mm})$.

11 Valores percentuais de escoamento pelo colmo (Ec), interceptação foliar (INT) e precipitação interna (PI), em relação à precipitação total, nas alturas de coleta de água de 0,00 e $0,25 \mathrm{~m}$ em relação ao solo para as três parcelas analisadas

12 Valores percentuais de escoamento pelo colmo (Ec), interceptação foliar (INT) e precipitação interna (PI), em relação à precipitação total, nas alturas de coleta de água de 0,00, 0,50 e 1,40 m em relação ao solo para as três parcelas analisadas. 
Página

13 Valores médios de concentrações de sulfato de amônio $\left.\left(\mathrm{NH}_{4}\right)_{2} \mathrm{SO}_{4}\right)$, cloreto de potássio (KCL) e sulfato de amônio mais cloreto de potássio juntos para as três parcelas na época $(\mathrm{E} 1) .(\mathrm{NH} 4)_{2} \mathrm{SO}_{4}=\mathrm{SA}$.

14 Valores médios de concentrações de sulfato de amônio $\left.\left(\mathrm{NH}_{4}\right)_{2} \mathrm{SO}_{4}\right)$, cloreto de potássio (KCL) e sulfato de amônio mais cloreto de potássio juntos para as duas posições $(0,00$ e $0,25 \mathrm{~m})$ e acima do dossel da cultura na época (E2). $\left(\mathrm{NH}_{4}\right)_{2} \mathrm{SO}_{4}=\mathrm{SA}$

15 Valores médios de concentrações de sulfato de amônio $\left(\mathrm{NH}_{4}\right)_{2} \mathrm{SO}_{4}$, cloreto de potássio (KCL) e sulfato de amônio mais cloreto de potássio juntos para as três posições $(0,00,0,50$ e $1,40 \mathrm{~m})$ e acima do dossel da cultura na época (E3). $\left(\mathrm{NH}_{4}\right)_{2} \mathrm{SO}_{4}=\mathrm{SA}$

16 Relação entre condutividade elétrica $\mathrm{CE}\left(\mathrm{dS} \mathrm{m} \mathrm{m}^{-1}\right)$ e concentrações $\left(\mathrm{g} \mathrm{L}^{-1}\right)$ de nitrogênio $(\mathrm{N})$ e potássio $\left(\mathrm{K}_{2} \mathrm{O}\right)$ e os dois juntos $\left(\mathrm{N}+\mathrm{K}_{2} \mathrm{O}\right)$ para as três caldas formuladas ( $\mathrm{kg}$ de fertilizante / volume de solução) no tanque de fertilizante na época $(\mathrm{E} 1) . \mathrm{SA}=\left(\mathrm{NH}_{4}\right)_{2} \mathrm{SO}_{4}$

17 Relação entre condutividade elétrica $\mathrm{CE}\left(\mathrm{dS} \mathrm{m} \mathrm{m}^{-1}\right)$ e concentrações $\left(\mathrm{g} \mathrm{L}^{-1}\right)$ de nitrogênio $(\mathrm{N})$ e potássio $\left(\mathrm{K}_{2} \mathrm{O}\right)$ e os dois juntos $\left(\mathrm{N}+\mathrm{K}_{2} \mathrm{O}\right)$ para as três caldas formuladas ( $\mathrm{kg}$ de fertilizante / volume de solução) no tanque de fertilizante na época (E2). $\mathrm{SA}=\left(\mathrm{NH}_{4}\right)_{2} \mathrm{SO}_{4}$

18 Relação entre condutividade elétrica $\mathrm{CE}\left(\mathrm{dS} \mathrm{m}^{-1}\right)$ e concentrações $\left(\mathrm{g} \mathrm{L}^{-1}\right)$ de nitrogênio $(\mathrm{N})$ e potássio $\left(\mathrm{K}_{2} \mathrm{O}\right)$ e os dois juntos $\left(\mathrm{N}+\mathrm{K}_{2} \mathrm{O}\right)$ para as três caldas formuladas ( $\mathrm{kg}$ de fertilizante / volume de solução) no tanque de fertilizante na época (E3). $\mathrm{SA}=\left(\mathrm{NH}_{4}\right)_{2} \mathrm{SO}_{4}$

19 Lâmina interceptada (INT, mm) em função do desenvolvimento relativo da cultura (Dr).

20 Quantidade de potássio interceptado $\left(\mathrm{QK}, \mathrm{t} \mathrm{ha}^{-1}\right)$ em função do desenvolvimento relativo da cultura (Dr)

21 Quantidade de nitrogênio interceptado $\left(\mathrm{QN}, \mathrm{t} \mathrm{ha}^{-1}\right)$ em função do desenvolvimento relativo da cultura (Dr).

22 Lâmina de água interceptada (INT, mm) em função do índice de área foliar (IAF, $\mathrm{m}^{2} \mathrm{~m}^{-2}$ ). 
Página

23 Quantidade de potássio interceptado $\left(\mathrm{QK}, \mathrm{t} \mathrm{ha}^{-\mathrm{I}}\right)$ em função do índice de área foliar (IAF, $\mathrm{m}^{2} \mathrm{~m}^{-2}$ ) .70

24 Quantidade de nitrogênio interceptado ( $\left.\mathrm{QN}, \mathrm{t} \mathrm{ha}^{-1}\right)$ em função do índice de área foliar (IAF, $\mathrm{m}^{2} \mathrm{~m}^{-2}$ )

25 Variação do potencial mátrico da água nas profundidades de 0,20 e 0,40m no solo cultivado com a cultura do milho 


\section{LISTA DE TABELAS}

Página

1 Especificações técnicas do equipamento de irrigação e bomba injetora de fertilizantes.

2 Altura das "piscinas", área de coleta e número de plantas dentro de cada "piscina" para a época de coleta (E2).

3 Altura das "piscinas", área de coleta e número de plantas dentro de cada "piscina" para a época de coleta (E3).

$4 \quad$ Épocas e quantidades de fertilizantes aplicadas na semeadura e nas três fases de desenvolvimento da cultura do milho analisadas.

5 Esquema da análise de variância utilizado para avaliar a retenção da lâmina de água e fertilizantes no dossel das plantas.

6 Valores médios de lâminas interceptadas (INT) em relação à precipitação total aplicada via pivô central e índice de área foliar (IAF), coletados na planta para a época $(E 1)$.

7 Valores médios de lâminas coletadas referentes às partições em precipitação interna (PI), escoamento pelo colmo (Ec) e interceptação foliar (INT) em relação à precipitação total aplicada via pivô central e índice de área foliar (IAF), coletados nas duas alturas na planta para a época (E2).

8 Valores médios de lâminas coletadas referentes às partições em precipitação interna (PI), escoamento pelo colmo (Ec) e interceptação foliar (INT) em relação à precipitação total aplicada via pivô central e índice de área foliar (IAF), coletados nas três alturas na planta para a época (E3)...

9 Valores médios de índice de área foliar (IAF), lâmina de água interceptada (INT), escoamento pelo colmo $(\mathrm{Ec})$, precipitação interna (PI), concentração de nitrogênio $\left(\mathrm{C}_{\mathrm{N}}\right)$, potássio $\left(\mathrm{C}_{\mathrm{K}}\right)$, nitrogênio mais potássio $\left(\mathrm{C}_{\mathrm{NK}}\right)$, interceptados pelo dossel da cultura para época (E2).

10 Valores médios de índice de área foliar (IAF), lâmina de água interceptada (INT), escoamento pelo colmo (Ec), precipitação interna (PI), concentração de nitrogênio $\left(C_{N}\right)$, potássio $\left(C_{K}\right)$, nitrogênio mais potássio $\left(C_{N K}\right)$, interceptados pelo dossel da cultura para época (E3). 
Página

11 Valores médios de índice de área foliar (IAF), lâmina de água interceptada (INT), concentração de nitrogênio $\left(C_{N}\right)$, potássio $\left(C_{K}\right)$, nitrogênio mais potássio $\left(\mathrm{C}_{\mathrm{NK}}\right)$, interceptados pelo dossel da cultura para os três estádios de desenvolvimento 4,8 e 12 folhas.

12 Temperaturas máximas $\left(\mathrm{T} 1,{ }^{\circ} \mathrm{C}\right)$ e mínimas $\left(\mathrm{T} 2,{ }^{\circ} \mathrm{C}\right)$ do ar, número de graus-dia, estádio fenológico, número de dias após a emergência (DAE) e desenvolvimento relativo da cultura (Dr) de milho desde a emergência (7/set) até 4 folhas (30/set)

13 Temperaturas máximas $\left(\mathrm{T} 1,{ }^{\circ} \mathrm{C}\right)$ e mínimas $\left(\mathrm{T} 2,{ }^{\circ} \mathrm{C}\right)$ do ar, número de graus-dia, estádio fenológico, número de dias após a emergência (DAE) e desenvolvimento relativo da cultura (Dr) de milho desde 4 folhas (01/out) até 13 folhas (05/nov).

14 Temperaturas máximas $\left(\mathrm{T} 1,{ }^{\circ} \mathrm{C}\right)$ e mínimas $\left(\mathrm{T} 2,{ }^{\circ} \mathrm{C}\right)$ do ar, número de graus-dia, estádio fenológico, número de dias após a emergência (DAE) e desenvolvimento relativo da cultura (Dr) de milho desde 13 folhas (06/nov) até o início do florescimento (14/nov).

15 Modelo referente à estimativa da lâmina interceptada (INT, mm) em função do desenvolvimento relativo da cultura (Dr), com os respectivos valores de coeficiente de correlação ( $\mathrm{r}$ ), número de observações (n), desvio-padrão do erro (s, mm) e valor $F$.

16 Modelo referente à estimativa da quantidade de potássio $\left(\mathrm{QK}, \mathrm{t}_{\mathrm{ha}}{ }^{-1}\right)$ interceptado em função do desenvolvimento relativo da cultura (Dr), com os respectivos valores de coeficiente correlação (r), número de observações $(n)$, desvio-padrão do erro $\left(s, t h^{-1}\right)$ e valor $F$.

17 Modelo referente à estimativa da quantidade de nitrogênio $\left(\mathrm{QN}, \mathrm{t} \mathrm{ha}^{-\mathrm{I}}\right)$ interceptado em função do desenvolvimento relativo da cultura (Dr), com os respectivos valores de coeficiente de correlação (r), número de observações $(n)$, desvio-padrão do erro $\left(s, t h^{-1}\right)$ e valor $F$.

18 Modelo referente à estimativa da lâmina interceptada (INT, $\mathrm{mm}$ ) em função do índice de área foliar (IAF, $\mathrm{m}^{2} \mathrm{~m}^{-2}$ ), com os respectivos valoress de coeficiente de correlação ( $\mathrm{r}$ ), número de observações $(\mathrm{n})$, desvio-padrão do erro (s, $\mathrm{mm}$ ) e valor $\mathrm{F}$. 
Página

19 Modelo referente à estimativa da quantidade de potássio $\left(\mathrm{QK}, \mathrm{t} \mathrm{ha}^{-1}\right)$ interceptado em função do índice de área foliar (IAF, $\mathrm{m}^{2} \mathrm{~m}^{-2}$ ), com os respectivos valores de coeficiente de correlação (r), número de observações (n), desvio-padrão do erro $\left(s, t\right.$ ha $\left.{ }^{-1}\right)$ e valor $F$

20 Modelo referente à estimativa da quantidade de nitrogênio $\left(\mathrm{QN}, \mathrm{t} \mathrm{ha}^{-1}\right)$ interceptado em função do índice de área foliar (IAF, $\mathrm{m}^{2} \mathrm{~m}^{-2}$ ), com os respectivos valores de coeficiente de correlação $(\mathrm{r})$, número de observações (n), desvio-padrão do erro $\left(\mathrm{s}, \mathrm{t} \mathrm{ha}^{-1}\right)$ e valor $\mathrm{F}$.

21 Variáveis climáticas observadas às 6:30h

22 Valores médios de lâminas ( $\mathrm{mm}$ ) obtidos nas 3 linhas de coletores, referentes às épocas $(\mathrm{E} 1),(\mathrm{E} 2)$ e (E3).

23 Valores de índice de área foliar (IAF), desenvolvimento relativo da cultura (Dr), Interceptação foliar da lâmina (INT), concentração de fertilizante $\left(\mathrm{C}_{\mathrm{N}}, \mathrm{C}_{\mathrm{K}}\right.$ e $\left.\mathrm{C}_{\mathrm{NK}}\right)$ para as (E1), (E2) e (E3), correspondentes aos estádios fenológicos de 4,8 e 12 folhas.

24 Caldas formuladas em laboratório com os valores de diluição $(\mathrm{ml})$, condutividade elétrica da água de diluição $\left(\mathrm{dS} \mathrm{m} \mathrm{m}^{-1}\right)$, razão de diluição, concentração da calda observada $\left(\mathrm{g} \mathrm{L}^{-1}\right)$, concentração da calda estimada $\left(\mathrm{g} \mathrm{L}^{-1}\right)$, quantidade de fertilizante diluídos $(\mathrm{kg})$ por volume no tanque $(\mathrm{L})$ e diferenças entre calda de laboratório (1) e a formulada em campo (2)

25 Valores médios de concentrações de fertilizantes obtidos em função das condutividades elétricas observadas nos coletores próximos ao solo e acima do dossel, estimadas através das equações ajustadas, para as três caldas formuladas na época El (4 folhas)

26 Valores médios de concentrações de fertilizantes obtidos em função das condutividades elétricas observadas nas alturas de coleta 0,00 e $0,25 \mathrm{~m}$ e acima do dossel, estimadas através equações ajustadas para as três caldas formuladas na época E2 ( 8 folhas).

27 Valores médios de concentrações de fertilizantes obtidos em função das condutividades elétricas observadas nas alturas de coleta 0,00 e 0,50 e 1,40 m e acima do dossel, estimadas através das equações ajustadas para as três caldas formuladas na época E3 ( 12 folhas). 


\title{
DISTRIBUIÇÃO DE NITROGÊNIO E POTÁSSIO NA CULTURA DE MILHO (Zea mays L.) APLICADOS VIA PIVÔ CENTRAL
}

\author{
Autor: Dálcio Ricardo Botelho Alves \\ Orientador: Prof. Dr. José Antonio Frizzone \\ Co-Orientador: Prof. Dr. Durval Dourado Neto
}

\section{RESUMO}

O presente trabalho teve como objetivo determinar a lâmina de água e as quantidades de nitrogênio e potássio retidas na folhagem da cultura do milho para fins de quimigação, sendo também ajustados modelos durante três fases fenológicas (4, 8 e 12 folhas) do híbrido CARGIL 909. Para coleta da água foram utilizados coletores plásticos presos ao colmo do milho e lonas plásticas instaladas nos dois lados da linha de plantas, em três alturas em relação ao solo: terços inferior, médio e superior. Analisaram-se a repartição dos valores de precipitação interna (PI), o escoamento pelo colmo (Ec) e a interceptação foliar da lâmina aplicada (INT). Foram calculados valores médios de PI, INT e Ec para as alturas de coleta de 0,0 e $0,25 \mathrm{~m}$, de 85,57 e $88,31 \%$, 6,56 e 5,57\%, e 7,87 e 6,12\%, respectivamente, para um índice de área foliar (IAF) 3. Nos estádios mais desenvolvidos (IAF $=4,35)$, os maiores valores observados de PI, INT e Ec foram 83,93, 6,89 e 13,44\%, respectivamente, para todas as alturas de coleta analisadas. Com aumento da altura de coleta de água em relação ao nível do solo, observaram-se um acréscimo na estimativa dos valores de precipitação interna e escoamento pelo colmo e uma redução nos valores de interceptação foliar. No estádio fenológico correspondente a 12 folhas, as três alturas estudadas na planta promoveram diferenças significativas somente para a variável INT, não se verificando esse efeito para PI e EC. As concentrações de fertilizantes variaram para os três terços estudados. A lâmina média de água interceptada pelo dossel das plantas pode ser estimada em função do desenvolvimento relativo ( $\mathrm{Dr}$ ) da cultura ou pelo índice de área foliar. As quantidades médias de nitrogênio e potássio, visando à aplicação foliar de fertilizantes 
na cultura do milho, podem ser estimadas pelos modelos, em função do desenvolvimento relativo da cultura ou do índice de área foliar. A fertigação com o propósito de aplicar nitrogênio e potássio via foliar não é recomendada (os valores médios interceptados de nitrogênio e potássio foram de 1,56 e 19,4\% para 4 e 12 folhas, respectivamente). 


\title{
NITROGEN AND POTASSIUM DISTRIBUTION APPLIED ON THE MAIZE (Zea mays L.) CROP BY CENTER PIVOT
}

\author{
Author: Dálcio Ricardo Botelho Alves \\ Adviser: Prof. Dr. José Antonio Frizzone \\ Co-Adviser: Prof. Dr. Durval Dourado Neto
}

This research had the purpose of evaluating and estimating the nitrogen and potasssium amounts and the water depth retained on the maize crop canopy after chemigation. Models were adjusted during three phenological stages (4, 8 and 12 leaves) for the hybrid C- 909. In order to collect water, plastic recipients were attached to the maize stalks and plastic sheets were installed over both sides of the plant rows, positioned at three levels (sampling heigths, inferior, medium and superior thirds). The following parameters were analized: internal precipitation (PI), flow off the stalks (Ec) and foliar interception (INT). Mean values of PI, INT, and Ec were calculated for 0,00 and $0,25 \mathrm{~m}$ sampling heights, respectively, $85,75 \%$ and $88,31 \% ; 6,56 \%$ and $5,57 \% ; 7,87 \%$ and $6,12 \%$ for a leaf area index (LAI) 3 . In the latter developmental stages ( $\mathrm{LAI}=4,35$ ), the higher values of PI, INT and Ec observed were 83,93, 6,89 and 13,44\%, respectively, for each sampling height. PI and Ec increased, and INT decreased as the sampling height increased. At the fenological stage 3 (12 leaves) sigfinicant differences were observed only for INT as the sampling height. The fertilizers concentration varied along the three thirds studied. The water depht intercepted by the crop canopy stage could be estimated as a function of the crop relative developmental stage, or leaf area index (LAI). The mean amounts of nitrogen and potassium to be applied in a maize crop via chemigation, could be estimated through models as a function of relative developmental stage or leaf area index (LAI). The fertigation with the purpose to apply foliar nitrogen and potassium is not recommended (the mean values of foliar nitogen and potassium were 1,56 and $19,4 \%$ to 4 and 12 leaves, respectively). 


\section{INTRODUÇÃO}

Considerando-se a importância da cultura do milho, o custo de produção e seu valor econômico, torna-se necessário o desenvolvimento de pesquisas para oferecer aos agricultores sistemas de produção economicamente viáveis, que propiciem aumentos significativos de produtividade, e que diminuam os riscos de insucesso. Dessa forma, torna-se necessário o uso de técnicas que aumentem a produtividade da cultura e, conseqüentemente, o retorno econômico.

Entre as várias técnicas de aplicação de produtos químicos na agricultura, destaca-se a quimigação, como uma opção de investimento com retorno rápido, apresentando inúmeras vantagens em relação às convencionais. Para realizá-la, sobressai o sistema de irrigação pivô central, que é amplamente utilizado para a aplicação de produtos químicos em geral. Combinando-se a elevada uniformidade de distribuição do sistema pivô central com a sua ampla capacidade de aplicação, pode-se aplicar uma grande variedade de produtos requeridos pela cultura, em todo o seu ciclo vegetativo, com elevada eficiência, promovendo o que se chama de quimigação total.

A uniformidade de aplicação de água reflete apenas como a água é distribuída na superfície do solo na ausência de culturas. No entanto, na presença da cultura, a água e os produtos químicos são redistribuídos entre o solo e a parte aérea. Portanto, a distribuição de produtos químicos depende de vários fatores tais como: uniformidade de aplicação de água, lâmina de água aplicada, produto químico utilizado (solubilidade), clima (vento e umidade relativa) e planta (densidade de semeadura, arquitetura da planta e estádio fenológico). 
Dessa forma, torna-se evidente a importância da cultura na uniformidade e eficiência da distribuição de água e produtos químicos via irrigação, e da necessidade de determinar a potencialidade da aplicação de agroquímicos na folhagem da cultura.

A realização deste trabalho serve como subsídio para definir a viabilidade técnica da fertirrigação, cujo o alvo é a folha. Para tal, pressupõe-se que a quantidade de fertilizante que fica retido no dossel da cultura do milho é proporcional à quantidade de água que fica retida.

O presente trabalho teve como objetivos específicos determinar, em função do índice de área foliar (IAF), a quantidade relativa do produto aplicado (nitrogênio e potássio) que atinge o solo e a planta, bem como a distribuição relativa na parte aérea da cultura de milho (nos terços superior, médio e inferior), com a finalidade de verificar a viabilidade do uso da fertirrigação como alternativa para a adubação foliar.

Como objetivo geral este trabalho visa estudar a viabilidade técnica da aplicação foliar de fertilizante via água de irrigação. 


\section{REVISÃO DE LITERATURA}

\subsection{Quimigação}

A quimigação é a técnica pela qual os produtos químicos são aplicados à lavoura através da água de irrigação. Este termo começou a ser usado nos Estados Unidos da América na década de 70 (Threadgill, 1985). O surgimento dos sistemas de irrigação tipo pivô central, na década de 40, e sua expansão na década de 50 permitiram ampliar a aplicação de fertilizantes por meio de água de irrigação (Dowler 1985).

A quimigação poderá se constituir em excelente prática agrícola, principalmente, no referente à economia de mão-de-obra e de óleo diesel, além de minimizar o depauperamento físico do solo e o risco de distribuição na área de fontes de inóculo, quando comparada com a aplicação via trator. Porém, para o seu sucesso é necessário conhecer suas limitações e alguns aspectos teóricos e práticos em função das características do produto químico e do equipamento (sistema de injeção de produto químico) a serem utilizados, sistema de irrigação, cultura, solo e o clima (Dourado Neto \& Fancelli, 1997).

É possível utilizar a quimigação com todos os métodos de irrigação, porém, com irrigação por aspersão os produtos químicos podem ser aplicados tanto no solo quanto nas folhas (Threadgill, 1991b). Ao contrário dos sistemas de irrigação localizada, os sistemas de irrigação por aspersão são mais adequados a quimigação pulverizada (Papadopoulos, 1999).

Potencialmente, todos produtos químicos podem ser aplicados por meio dos sistemas de irrigação por aspersão (Ramos \& Mantovani, 1994), particularmente, o 
sistema tipo pivô central e linear móvel são mais indicados para esta técnica devido à alta uniformidade de distribuição de água (Frizzone et al., 1994).

Pesquisas recentes e avanços obtidos nos sistemas de irrigação e equipamentos de injeção permitiram uma expansão do número de produtos aplicáveis pela água de irrigação: herbicidas, inseticidas, fungicidas, nematicidas, reguladores de crescimento e agentes de controle biológico (Dowler et al., 1989; Threadgilll et al., 1991a).

As principais vantagens da quimigação são: diversificar o uso do sistema de irrigação; permitir a aplicação dos produtos químicos necessários, em tempo oportuno, independentemente da cobertura do solo e do estádio de desenvolvimento da cultura; controlar melhor a aplicação de nutrientes para as plantas ao longo do ciclo de cultivo reduzindo a possibilidade de lixiviação; reduzir a necessidade de compra e manutenção de equipamentos utilizados na aplicação convencional; reduzir da compactação do solo e dos danos mecânicos à cultura; incorporar e ativar o produto químico a uma profundidade determinada; reduzir a deriva; e, em geral, reduzir bastante os custos de aplicação (Shani, 1981; Roberts \& Potts, 1991; Vieira, 1994).

As eventuais desvantagens da quimigação incluem a possibilidade de contaminação do meio ambiente, corrosão dos equipamentos, indisponibilidade de formulações apropriadas e de defensivos registrados para aplicação via água de irrigação, exige equipamentos próprios e treinamento do operador (Vieira, 1994), distribuição desigual de produtos químicos quando o dimensionamento ou a operação do sistema de irrigação são inadequados, precipitação de materiais químicos e/ou entupimento das saídas (Papadopoulos, 1999), calibração da taxa de injeção apropriada para cada sistema de irrigação, podendo requerer mudanças durante o período de quimigação (Frizzone et al., 1994).

Diversos equipamentos são utilizados na injeção de fertilizantes e outros produtos na água de irrigação, os quais diferem quanto à fonte de energia, ao funcionamento, a eficiência e ao preço. Os equipamentos podem trabalhar com pressão efetiva positiva (bombas dosificadoras), utilizando a diferença de pressão no seu funcionamento (tanque de derivação de fluxo), e com pressão efetiva negativa, como o 
injetor venturi (Frizzone et al., 1994). Costa et al. (1986) e Zanini (1987) comentam que os sistemas que utilizam pressão positiva são os mais usados, em razão de não haver variação temporal da concentração de fertilizantes no reservatório.

$\mathrm{Na}$ fertirrigação, tanto a irrigação como a fertilização afetam o comportamento vegetal, sendo que o ajuste em um dos fatores pode determinar os limites impostos pelo outro. Para se obter o desempenho vegetal ideal na fertirrigação, todos os fatores que contribuem para o aumento da fertirrigação devem ser balanceados de modo que nenhum imponha um limite significativo. As exigências reais de água e nutrientes da cultura, aliada à distribuição uniforme tanto da água como dos nutrientes, constituem parâmetros importantes para uma expressiva prática de fertirrigação (Papadopoulos, 1999).

Para o uso da fertirrigação, são desejáveis algumas características dos fertilizantes, tais como: rápida, completa e alta solubilidade; elevada pureza; baixo poder corrosivo; baixa volatilidade; alta concentração; compatibilidade de mistura e baixo custo (Frizzone et al., 1994). Para preparar uma solução concentrada, recomenda-se não ultrapassar o limite de $75 \%$ da solubilidade do produto, devido as possíveis impurezas encontradas no fertilizante (Pizarro, 1987).

A uniformidade de aplicação do produto químico, fator essencial para o sucesso da quimigação Vieira (1994), depende de alguns fatores tais como: calda utilizada $\left(\mathrm{L} \mathrm{ha}^{-1}\right)$; regime de escoamento hidráulico; volume máximo armazenável de calda (o qual é dependente do índice de área foliar), arquitetura de planta e natureza das folhas (cerosidade, principalmente) e propriedades do produto químico, principalmente, a solubilidade, e tensão superficial (Dourado Neto \& Fancelli, 1999). Sistemas de irrigação com aplicação desuniforme podem aplicar quantidades distintas de água tendo como conseqüência imediata a aplicação de quantidades desuniformes de adubo na área, podendo passar da situação de deficiência para fitotoxidez, caso não seja verificada a oscilação dos valores de lâminas aplicadas em torno da lâmina média (Hernandez, 1993; Dourado Neto \& Fancelli, 1999).

O nitrogênio é o elemento mais comumente utilizado na fertirrigação por ser altamente solúvel em água e apresentar susceptibilidade à lixiviação. A eficiência de 
aplicação de nitrogênio via fertirrigação é quase sempre maior do que qualquer outro método. A precisão na aplicação confina o fertilizante na zona radicular da cultura, reduzindo a volatização, enquanto o parcelamento das aplicações maximiza a absorção pelas raízes e minimiza a lixiviação (Dourado Neto \& Fancelli, 1999). O parcelamento do nitrogênio, aplicado via água de irrigação, deve ser feito de acordo com a demanda de nutrientes pela planta, nos seus diversos estádios de desenvolvimento fisiológico, determinada através da marcha de absorção de nutrientes da cultura (Costa et al., 1986).

Vitti et al. (1993) relatam que os fertilizantes sólidos nitrogenados (uréia, nitrato de amônio e sulfato amônio) são os mais solúveis em água, não apresentando nenhum problema para serem utilizados na irrigação. A aplicação de potássio junto com nitrogênio, via água de irrigação, é uma técnica muito utilizada por praticamente não apresentar problemas, devido à alta solubilidade da maioria dos sais de potássio. A escolha do fertilizante para uma aplicação mais específica deve se basear em vários fatores, tais como: forma, pureza, solubilidade e custo (Papadopoulos, 1999).

O potássio, macronutriente absorvido em grandes quantidades da solução do solo pelas raízes, é responsável pela sanidade e equilíbrio da planta (Pizarro, 1987). Este macronutriente, essencial na formação e migração de açúcares e amido, interfere ativamente no processo de abertura e fechamento dos estômatos, reduzindo a transpiração da planta e contribuindo para o desenvolvimento de raízes, aumento do tamanho e da qualidade dos frutos. Qualquer que seja o adubo, este deve ser parcelado conforme a freqüência de irrigação, pois os melhores resultados da fertirrigação são obtidos com aplicações mais freqüentes (Medina San Juan, 1988). Em solos de textura arenosa, que normalmente apresentam baixa CTC efetiva e alto potencial de perdas por lixiviação, a aplicação parcelada de potássio via água de irrigação é extremamente vantajosa, permitindo maior eficiência no manejo desse nutriente. Portanto, a época e o número de aplicações dependem da curva de absorção de nutrientes pela cultura (Coelho, 1994).

Além dos fertilizantes na forma isolada, ou em combinações de dois ou mais nutrientes, o mercado brasileiro apresenta fertilizantes na forma fluída. Os adubos líquidos podem estar na forma de soluções claras, soluções coloidais e misturas em 
suspensão (Boaretto et al., 1991; Vitti et al. 1993). O uran comercializado no Brasil contém $32 \%$ de nitrogênio total, sendo $14 \% \mathrm{~N}-\mathrm{NH}_{2}, 9 \% \mathrm{~N}-\mathrm{NO}_{3}$ e $9 \% \mathrm{~N}-\mathrm{NH}_{4}$. Essa solução nitrogenada, por possuir o nitrogênio em formas mais estáveis, oferece menor possibilidade de perdas por volatilização durante o uso. Misturas contendo fósforo são encontradas na forma 06-30-00 e 10-30-00, podendo ser empregadas puras, em pulverizações foliares por avião, diluídas em fertirrigação ou aplicadas via solo (Coelho, 1994).

\subsection{A quimigação na cultura do milho}

Devido às facilidades que os sistemas de irrigação oferecem para a aplicação de fertilizantes via água de irrigação, diversos experimentos têm sido conduzidos com intuito de fornecer informações relevantes sobre o manejo da quimigação na cultura do milho.

Alves et al. (1992) compararam métodos de aplicação de N-uréia ao solo e via água de irrigação, em milho cultivado em dois latossolos de textura diferente, verificaram que a aplicação de $120 \mathrm{~kg} \mathrm{~N} \mathrm{ha}^{-1}$ pelo método convencional, no estádio de desenvolvimento correspondente a 8 a 10 folhas, resultou em produção de grãos semelhante à obtida com a mesma quantidade de uréia aplicada via irrigação, parcelada em três, quatro e seis vezes.

Rehm \& Wiese (1975) estudaram o efeito de métodos de aplicação de nitrogênio sobre a produção do milho irrigado, e concluíram que houve efeito da textura do perfil do solo. Em solo arenoso, com acúmulo de silte a $60 \mathrm{~cm}$ de profundidade, não foi verificado efeito do método de aplicação de nitrogênio sobre a produção. Entretanto, em solo arenoso, cujo perfil não apresentava esse acúmulo, a aplicação parcela de nitrogênio via água de irrigação aumentou a produção de grãos e a recuperação de nitrogênio, quando comparada com a aplicação do elemento no solo, em pré-plantio e cobertura. 
A aplicação de fertilizantes fosfatados é questionável, em função da baixa difusão do elemento no solo. Experimentos conduzidos por Herget \& Reuss (1976) visando comparar a utilização do fósforo pelo milho e a movimentação desse nutriente no perfil do solo, quando aplicado via água de irrigação e no solo, pelo método convencional, em solo arenoso e argiloso, não observaram para o solo arenoso diferenças significativas na produção do milho com aplicação do fósforo a lanço e incorporado ao solo antes do plantio e via água de irrigação, em aplicação parcelada ou única, após a emergência das plântulas. Entretanto, no solo argiloso, houve melhores resultados (desenvolvimento vegetativo inicial e produtividade) quando o fósforo foi aplicado a lanço e incorporado ao solo em pré-plantio.

Rehm et al. (1982) concluíram que exceto para o $\mathrm{N}$ e $\mathrm{S}$, os métodos convencionais de aplicação de fertilizante tiveram a produção equivalente àquelas produzidas com aplicação via água de irrigação. Entretanto, nas situações em que foi detectada a deficiência do nutriente precocemente, na fase de crescimento, a aplicação de fertilizante fluido via água de irrigação resultou num acréscimo substancial na produção.

Gascho \& Hook (1985) desenvolveram um programa de fertirrigação para a cultura do milho para solos arenosos da Geórgia, recomendam que $25 \%$ do total de nitrogênio deve ser aplicado no plantio; $67,5 \%$ nos estádios de 6,8 e 12 folhas $(22,5 \%$ para cada estádio) e 7,5\% no florescimento. Entretanto, para as condições do Brasil, em geral, deve-se usar um maior número de aplicações quando se tratar de solos arenosos, áreas sujeitas a chuvas de alta intensidade, ou para altas doses (120 a $\left.200 \mathrm{~kg} \mathrm{ha}^{-1}\right)$ de nitrogênio (Coelho et al., 1991).

Uma forma de reduzir as perdas de nutrientes por lixiviação é através de um manejo de fertilizantes adequado, em que pequenas quantidades e aplicações mais freqüentes são requeridas. Rhoads \& Stanley Júnior, (1981), analisando o efeito do manejo de aplicação de fertilizantes na absorção de nutrientes e rendimento no milho irrigado, constataram que a absorção de $\mathrm{N}$ e P pelas plantas não foi influenciada pelo aumento do número de aplicações. Entretanto, houve uma significativa correlação negativa entre a absorção de $\mathrm{K}$ e o número de aplicações de fertilizantes. Essa relação 
entre absorção de nutrientes e rendimento o milho irrigado pode ser significativamente alterada por um estresse hídrico, especialmente, se ocorrer na fase de enchimento de grãos. Portanto, um aumento significativo de $65 \%$ no rendimento do milho irrigado foi verificado através de um intensivo manejo de água (Rhoads \& Stanley Júnior, 1973).

\subsection{Manejo de água e adubação na cultura de milho}

As fases mais sensíveis à deficiência de água na cultura de milho, em ordem decrescente, são: florescimento, enchimento dos grãos e desenvolvimento vegetativo (Museck \& Duser, 1980; Eck, 1986).

Após a implantação de um projeto de irrigação, o produtor deve ser orientado para obter o máximo de rendimento do sistema em uso. Isso significa estabelecer o momento de efetuar as irrigações e a lâmina de água a ser aplicada, evitando-se, assim, perdas de produção devido à falta ou excesso de água (Resende et al., 1990).

O manejo de irrigação pode ser efetuado utilizando vários métodos tais como: o balanço hídrico, o uso de tensiômetros e o uso do tanque classe A. Esses métodos possibilitam estimar a lâmina de água a ser aplicada e o momento de efetuar as irrigações (Resende et al., 1990).

Doorenbos \& Kassam (1994) comentam que, para se obter uma produção máxima de grãos, a cultura de milho, com período médio de amadurecimento. necessita de 500 a $800 \mathrm{~mm}$ de água, dependendo do clima. Deve-se acrescentar a essa quantidade às perdas durante o transporte e a aplicação. Os coeficientes de cultivo $(\mathrm{kc})$ nos diferentes estádios de crescimento da cultura do milho para a produção de grão são: estádio inicial, 0,3 - 05 (15 a 30 dias); estádio de desenvolvimento, 0,7 - 0,85 (30 a 45 dias); estádio intermediário, 1,05 - 1,2 (30 a 45 dias); estádio final, 0,8 - 0,9 (10 a 30 dias); e na colheita, 0,55-0,6.

$\mathrm{O}$ entendimento da interação entre o ambiente (elementos bióticos e abióticos) e a planta é de fundamental importância para melhor orientar ações de manejo 
no intuito de obter o rendimento agrícola almejado (Dourado Neto \& Fancelli, 1997). Torna-se também imprescindível a definição prévia do rendimento médio a ser atingido. Para tal, é necessário conhecer a cultura, bem como as condições de mercado e edafoclimáticas da propriedade agrícola.

Segundo Fancelli \& Dourado Neto (1996), a quantidade de nitrogênio a aplicar é definida em função do rendimento almejado, do teor médio de proteína no grão, do teor médio de nitrogênio na proteína, do índice de colheita, do teor médio de nitrogênio nas outras partes da planta, da quantidade relativa de nitrogênio fornecida pelo solo, e da eficiência de utilização de nitrogênio proveniente do fertilizante Recomendam o parcelamento da adubação nitrogenada, levando-se em consideração a fenologia da cultura do milho (estádios de definição da produção e marcha de absorção de nitrogênio), as condições climáticas e o tipo de solo. Com base em trabalhos desenvolvidos, recentemente, sugere-se, de maneira geral, a aplicação de $30 \mathrm{~kg} \mathrm{de} \mathrm{N} \mathrm{ha}^{-1}$ na semeadura, com o restante dividido em duas parcelas iguais aplicadas quando a planta apresentar 4 a 8 folhas, respectivamente. No caso de solos com baixo potencial de lixiviação (solos argilosos), sugerem reduzir o parcelamento a duas aplicações: na semeadura (30 a $40 \mathrm{~kg} \mathrm{de} \mathrm{N} \mathrm{ha}^{-1}$ ) e quando a planta apresentar 6 folhas desenroladas.

$\mathrm{Na}$ literatura encontram-se inúmeros trabalhos relacionados com a adubação na cultura do milho, que apresentam resultados diferenciados para situações distintas.

Segundo Resende et al. (1990) a cultura de milho de sequeiro, com produtividade esperada de $8 \mathrm{tha}^{-1}$, retira do solo $175 \mathrm{~kg} \mathrm{ha}^{-1}$ de $\mathrm{N}, 75 \mathrm{~kg} \mathrm{ha}^{-1}$ de $\mathrm{P}_{2} \mathrm{O}_{5} \mathrm{e}$ $150 \mathrm{~kg} \mathrm{ha}^{-1}$ de $\mathrm{K}_{2} \mathrm{O}$, sendo que $80 \%$ do fósforo e potássio retornam ao solo com a palhada. Portanto, para adubação da cultura do milho em sistemas irrigados, com produtividade esperada maior do que aquelas que constam nas tabelas de recomendação para condições de sequeiro, a recomendação de $\mathrm{N}, \mathrm{P}_{2} \mathrm{O}_{5}$ e $\mathrm{K}_{2} \mathrm{O}$ deve ser aumentada, visando a atender a essa maior extração e manter o nível de fertilidade do solo nas culturas subseqüentes.

Monteiro et al. (1989) estudando os efeitos de lâminas de irrigação e níveis de nitrogênio no rendimento do milho verde, verificaram que a maior produção de 
espigas (14194kg ha ${ }^{-1}$ ) foi obtida com uma lâmina equivalente a $50 \%$ da evapotranspiração de referência e uma aplicação de $160 \mathrm{~kg} \mathrm{ha}^{-1}$ de nitrogênio. No entanto, vários trabalhos citados pelos autores, apresentam valores entre $180 \mathrm{e}$ $200 \mathrm{~kg} \mathrm{ha}^{-1}$ de nitrogênio. Mendonça (1994), através de uma função de produção, estimou a produtividade máxima de milho irrigado em $7663,65 \mathrm{~kg} \mathrm{ha}^{-1}$, para uma dose de $242,6 \mathrm{~kg} \mathrm{ha}^{-1}$ de nitrogênio

Coelho et al. (1992) verificaram uma pronunciada resposta à aplicação de nitrogênio no rendimento dos grãos de milho da dose 0 para $120 \mathrm{~kg} \mathrm{ha}^{-1}$ de $\mathrm{N}$ (3943 para $7110 \mathrm{~kg} \mathrm{ha}^{-1}$ ), correspondendo a um incremento de $80 \%$. A dose de $\mathrm{N}$ necessária para atingir $90 \%$ da produção máxima foi de $80 \mathrm{~kg} \mathrm{ha}^{-1}$. Também observaram que as fontes de $\mathrm{N}$ (uréia e sulfato de amônio) não diferiram em seus efeitos na produção de grãos e $\mathrm{N}$ absorvido, sendo a eficiência de utilização de 58 e $56 \mathrm{~kg}$ de grãos $/ \mathrm{kg}$ de $\mathrm{N}$ absorvido, respectivamente, para uréia e sulfato de amônio.

O nitrogênio é um dos nutrientes que apresenta os maiores efeitos no aumento da produção de grãos da cultura de milho. Fundamentalmente, o nitrogênio participa da formação da proteína do grão (Bull, 1993).

Yamada (1995) relata que o balanço de nitrogênio no sistema soloplanta-atmosfera é dado pela diferença entre os ganhos e perdas. Segundo o autor, no geral, a literatura tem mostrado que o milho exporta cerca de 20 a $25 \mathrm{~kg}$ de $\mathrm{N}$ por tonelada de grãos colhidos. Sugere nesse trabalho, que para condições de plantio direto estabelecido ou convencional, com altos teores de matéria orgânica, o uso de $20-25 \mathrm{~kg}$ de $\mathrm{N}$ ha ${ }^{-1}$ na adubação de plantio com cobertura nitrogenada (junto com o potássio) feita logo após a semeadura (ao redor de duas semanas) e incorporada ao solo, poderá proporcionar boa probabilidade de resposta. Para solos de textura mais arenosa, recomenda-se uma segunda cobertura, apenas com nitrogênio.

As recomendações atuais para a adubação nitrogenada em cobertura são realizadas com base em curvas de resposta, histórico da área e produtividade esperada. Para obter altas produtividades em agricultura irrigada, onde prevalece o uso de alta tecnologia, (Coelho \& França, 1995) recomendam doses de nitrogênio variando de 100 a $200 \mathrm{~kg} \mathrm{ha}^{-1}$. 
Raij \& Cantarella (1996) recomendam a adubação nitrogenada de plantio entre 10 a $30 \mathrm{~kg} \mathrm{ha}^{-1}$ de $\mathrm{N}$, com adubação mineral de cobertura de 10 a $140 \mathrm{~kg} \mathrm{ha}^{-1} \mathrm{de} \mathrm{N}$, de acordo com a produtividade esperada.

$\mathrm{O}$ potássio é o nutriente mais exigido pelas plantas, após o nitrogênio. $\mathrm{O}$ potássio é absorvido pelas plantas da solução do solo, na forma iônica de $\mathrm{K}^{+}$.


competitiva (Raij, 1991 e Faquin, 1994). O requerimento de potássio para o crescimento ótimo das plantas está, aproximadamente, entre 2 a $5 \%$ na matéria seca, variando em função da espécie e do órgão analisado (Faquin, 1994).

A aplicação de potássio na cultura do milho, em geral, é menos freqüente e mais modesta que as observadas para o fósforo e o nitrogênio (Cantarella, 1993). Malavolta (1982) fez um levantamento de mais de 500 ensaios de milho conduzidos em vários Estados brasileiros, e verificou que apenas cerca de $26 \%$ deles reagiram à adição de potássio. Vasconcelos et al. (1982) observaram que, nos ensaios com respostas significativas, estas geralmente ocorreram até 40 a $60 \mathrm{~kg} \mathrm{ha}^{-1}$ de $\mathrm{K}_{2} \mathrm{O}$.

O potássio possui alguma semelhança com o fósforo, na absorção pela planta, pois, os dois nutrientes dependem de difusão para chegar à superficie das raízes. Contudo, sais de potássio apresentam, em geral, alta solubilidade e, assim, os teores de $\mathrm{K}^{+}$na solução do solo podem atingir concentrações bastante elevadas, dependendo do teor de ânions presentes, o que confere ao potássio uma mobilidade bem maior quando comparada com a do fósforo (Raij, 1991).

Roberts \& Potts (1991) comentam que a pesquisa usualmente não tem recomendado a aplicação de potássio através dos sistemas de irrigação, por razões de uso similares ao fósforo. Entretanto, segundo os autores, o potássio, em leves aplicações, tem sido aplicado com sucesso em solos arenosos via pivô central.

A interação entre o $\mathrm{N}$ e $\circ \mathrm{K}_{2} \mathrm{O}$ é importante também para outros parâmetros, como qualidade do produto, eficiência na utilização dos nutrientes, resistência a doenças, ao acamamento, ao bom desenvolvimento do colmo, órgão de reserva, de onde são drenados os nutrientes no enchimento de grãos (Coelho \& França, 1995). 


\subsection{Uniformidade de distribuição de água em pivô central}

A uniformidade de distribuição de água em sistemas de irrigação por aspersão tem sido avaliada por vários coeficientes de uniformidade estatístico.

Dentre estes, o coeficiente de uniformidade de Christiansen (CUC), desenvolvido por Christiansen (1942), tem sido o mais utilizado para avaliar o desempenho de um sistema de irrigação por aspersão, expresso pela equação:

$$
C U C=100\left[1-\frac{\sum_{i=1}^{n} S_{i}\left|X_{i}-X_{m}\right|}{n X_{i}}\right]
$$

em que CUC se refere ao Coeficiente de Uniformidade de Christiansen (\%), Xi à lâmina de água coletada no i-ésimo coletor $(\mathrm{mm}), \mathrm{Xm}$ à lâmina média coletada $(\mathrm{mm})$ e $\mathrm{n}$ ao número de coletores. Muitas críticas foram atribuídas a este coeficiente, principalmente por utilizar como medida de dispersão o desvio médio absoluto.

No entanto, deve-se considerar o processo de redistribuição de água no perfil do solo que afeta a uniformidade de distribuição abaixo da superfície. Especialmente em solos argilosos, que possuem maior habilidade para a redistribuição interna de água, ocorre um aumento considerável da uniformidade abaixo da superfície, com o decorrer do tempo (Rezende et al., 1992; Lima \& Alves, 1994). Vários coeficientes foram propostos como alternativa ao de Christiansen, no entanto, nenhum apresentou vantagens significativas.

Para o cálculo do coeficiente de uniformidade de distribuição de água em pivô central, é usual ponderar as lâminas de água coletadas nos pluviômetros, uma vez que cada coletor representa áreas progressivamente maiores, a partir do ponto do pivô. Heermann \& Hein (1968) propuseram uma modificação na equação de Christiansen, 
considerando como fator de ponderação a distância do coletor ( $\mathrm{i}$ ) ao ponto do pivô $\left(\mathrm{S}_{\mathrm{i}}\right)$. Desta forma, a equação (1) pode ser rescrita como:

$$
C U C=100\left[1-\frac{\sum_{i=1}^{n} S_{i}\left|X_{i}-X_{m p}\right|}{\sum_{i=1}^{n} S_{i} X_{i}}\right]
$$

em que CUC se refere ao coeficiente de uniformidade de Christiansen (\%), $X_{m p}$ à lâmina média ponderada $(\mathrm{mm}), X_{\mathrm{i}}$ à lâmina precipitada no coletor $\mathrm{i}(\mathrm{mm})$ e $S_{\mathrm{i}}$ ao número de ordem do coletor $\mathrm{i}$.

Bernardo (1989) relata que o coeficiente de uniformidade de Christiansen é o principal parâmetro para avaliar a uniformidade de aplicação de água. Para sistemas de irrigação do tipo pivô central, o autor recomenda os seguintes valores para este coeficiente: cultivos de alto valor comercial ou sistema radicular raso, CUC acima de $88 \%$; cultivos extensivos e sistema radicular médio, CUC de 80 a $90 \%$; para cultivos com sistema radicular profundo, CUC de 75 a $85 \%$.

Vários trabalhos têm demonstrado a relação existente entre a uniformidade de distribuição de água em pivô central e a velocidade de deslocamento desse equipamento. Santos (1988), Rezende (1992) e Cotrim (1988), avaliando o desempenho de sistemas de irrigação do tipo pivô central, verificaram que os maiores valores de CUC ocorreram nas menores velocidades de operação do equipamento. No entanto, para a quimigação, maiores velocidades tem sido propostas pelos fabricantes para a aplicação de produtos químicos via irrigação.

\subsection{Aplicação de produtos químicos via pivô central}

A aplicação de fertilizantes através de sistemas de irrigação por aspersão (pivô central) tem sido amplamente utilizada em quimigação. A fertilização geralmente tem sido restrita para alguns elementos, como nitrogênio, fósforo, potássio, magnésio, 
cálcio, enxofre e boro, com formulações líquida ou solúvel em água (Hickey et al., 1990).

Mais recentemente, os pivôs tem sido muito utilizados na aplicação de fertilizantes e produtos químicos, em várias culturas, aumentando a eficiência do produto aplicado, devido a facilidade de aplicar lâminas diferentes em função da sua velocidade de deslocamento (Roberts \& Potts, 1991).

A utilização desse sistema para a aplicação de produtos químicos está se tornando muito comum. Os produtores aplicam fertilizantes, herbicidas, inseticidas e fungicidas via pivô central, tornando essa prática importante nas atividades produtivas da agricultura irrigada (Costa et al., 1994). Os autores relatam ainda que os métodos de injeção empregados normalmente utilizam bombas de deslocamento positivo, que se caracterizam por baixas vazões e altas pressões, e são ideais para introdução de produtos químicos em pivô central.

As principais vantagens da bomba injetora são: o alto-grau de controle da dosagem e da escolha do momento da distribuição química, o controle centralizado e sofisticado, a portatibilidade, pequena perda de carga no sistema e custo de operacionalização relativamente barato (Papadopoulos, 1999).

As técnicas de quimigação e irrigação são antagônicas. No caso da irrigação o dimensionamento é feito em função da demanda evapotranspiratória máxima, em que os valores modais oscilam entre 4 e $9 \mathrm{~mm} \mathrm{dia}^{-1}$. Para a quimigação, o dimensionamento do sistema de irrigação poderia visar a lâmina correspondente à calda máxima, equivalente à aplicada via trator, de $400 \mathrm{~L} \mathrm{ha}^{-1}$. Nesse caso, o dimensionamento da lâmina de projeto, correspondente à regulagem do temporizador de $100 \%$, seria da ordem de 0,04 mm, o que é inviável na prática (Dourado Neto \& Fancelli, 1997).

No Brasil, grande parte dos pivôs centrais comerciais aplicam lâminas de 4 a $9 \mathrm{~mm}$ de água por volta $\left(40\right.$ a $90 \mathrm{~m}^{3} \mathrm{ha}^{-1}$ ). Quando o alvo das aplicações de agroquímicos são as folhas das plantas, a principal desvantagem do pivô central é o grande volume de água aplicado, resultando numa concentração muito baixa do produto na água de irrigação, além da maior parte do produto ser depositado no solo. Entretanto, resultados de pesquisas têm demonstrado a eficácia da quimigação de produtos químicos 
que atuam nas folhas, principalmente quando se usa formulação adequada (Vieira, 1994).

Young (1980) relata que o controle da lagarta no milho tem sido dificil com as técnicas de aplicação convencionais (pulverização). A máxima quantidade de água que pode ser aplicada economicamente com os equipamentos convencionais resulta em uma pobre penetração no dossel das culturas, como exemplo, a cultura do milho, devido ao baixo volume de água, que com isso não promove controle adequado de insetos sem múltiplas aplicações. $\mathrm{O}$ autor propôs o uso da água de irrigação para conduzir o inseticida e suprir o volume de água necessário para a penetração, particularmente nas reentrâncias das folhas onde as lagartas se alojam. Comparou ainda diferentes formulações de cloropyrifos (clorofosforados) para controlar a lagarta do cartucho no milho, e concluiu que o cloropyrifos + óleo aplicados via água de irrigação efetivamente controlou a larva da lagarta, pois o óleo permite maior retenção pelas folhagens do milho quando aplicados via água de irrigação. Observou que o controle de insetos com o inseticida formulado em óleo, resultaram em danos muitos baixos à cultura. Inseticidas insolúveis em água e solúveis em óleo são mantidos em gotículas encapsuladas, sem perder sua identidade na água, aderindo às partes aéreas das plantas e ao corpo do inseto, aumentando sua eficiência (Silveira et al., 1987).

Para a insetigação, a concentração do inseticida é drasticamente reduzida, em comparação com uma pulverização convencional. Embora menos concentrado, o inseticida atinge o local da praga de forma mais eficiente do que na pulverização, principalmente em plantas com arquitetura parecida com o milho, semelhante a um cálice, a qual favorece a captação da calda no cartucho e na bainha das folhas. A eficiência no controle da Spodoptera frugiperda em milho variou de $86,9 \%$ a $98,2 \%$ nos trabalhos conduzidos por Viana \& Costa (1989 e 1992).

Ramos \& Mantovani (1994) afirmam que os sistemas pivô central e linear são os que apresentam os maiores potenciais para a quimigação, por causa da sua elevada uniformidade de aplicação. Os autores comentam que combinando a elevada uniformidade de aplicação desses sistemas com a sua capacidade de aplicar todos os tipos de produtos químicos, pode-se aplicar todos os produtos requeridos pela cultura, 
em todo o seu ciclo vegetativo, com grande eficiência, fazendo o que se chama de quimigação total.

A uniformidade da irrigação pode apresentar valores distintos para a água e produto químico aplicado. Stone et al. (1994) obtiveram uniformidade de 93,5\% para a água e $83,9 \%$ para o produto, avaliando um sistema pivô central, durante a quimigação com inseticida formulado em óleo de amendoim. Tais diferenças devem-se a menor densidade do óleo que promove um acúmulo do produto na área mais próxima do aspersor, resultando numa distribuição diferenciada, que se refletiu no coeficiente de uniformidade. Cruz (1997) obteve valores de CUC de 91,08\% para a água de irrigação e $87,80 \%$ para a concentração de inseticida, indicando que a uniformidade de distribuição de água ao longo do pivô central representou bem a distribuição do inseticida pelo sistema de irrigação.

\subsection{Efeito da cultura na distribuição de água e produtos químicos}

A maioria dos trabalhos sobre interceptação foliar está relacionada com ecossistemas florestais e culturas perenes de grande porte. No entanto, para culturas anuais, existem poucos trabalhos sobre $\mathrm{o}$ assunto.

Haynes (1940) observou por um período de três anos a interceptação de água da chuva em diversas culturas, e, especificamente para o milho, verificou que de uma precipitação total de água de $682 \mathrm{~mm}$, houve uma penetração pelo dossel da cultura do milho de $479,8 \mathrm{~mm}$, ficando $202,7 \mathrm{~mm}$ retidos. O autor concluiu ainda que, desses $202,7 \mathrm{~mm}(29,7 \%)$ de água, $155,5 \mathrm{~mm}$ escoaram pelo colmo, e $47,2 \mathrm{~mm}(6,9 \%)$ foram interceptados pela cultura.

Leopoldo et al. (1981) com objetivo de estudar a interceptação da água de chuva sob uma cobertura de canavieira, verificaram que do total de $684 \mathrm{~mm}$ de chuva precipitados sobre a cultura, $384 \mathrm{~mm}$ corresponderam à precipitação interna, $267 \mathrm{~mm}$ ao escoamento pelo colmo, enquanto $28 \mathrm{~mm}$ fizeram parte da fração interceptada, correspondendo, em termos percentuais, a 56,9,39,0 e 4,1\%, respectivamente. Estes 
valores tornam-se importantes, em se tratando de irrigação, demonstrando que o comportamento da lâmina aplicada é muito variável e proporcional ao desenvolvimento da cultura, podendo influir diretamente na eficiência de irrigação. Vieira (1982) observou valores médios de interceptação de água de $24 \%$ e $11 \%$ para escoamento pelo caule da cana-de-açúcar.

Steiner et al. (1983), estudando as perdas e a repartição de água de um pivô central sob a cultura do milho, chegaram à conclusão de que, cerca de $50 \%$ da água que alcançou a superficie do solo através do escoamento pelo colmo e o restante sob a forma de respingos pelo dossel da cultura. As medidas de escoamento pelo colmo e interceptação pelo dossel foram feitas sob condições de um dossel desenvolvido, quando o índice de área foliar excedia o valor de 3 . Os dados mostraram que, da lâmina de irrigação aplicada de $33 \mathrm{~mm}$, foram interceptados $2,7 \mathrm{~mm}$ pela cultura do milho, correspondendo a $8,1 \%$ do total aplicado. Os autores relatam que a capacidade de armazenamento do dossel pode ser relativamente constante para uma dada condição de dossel cheio, mas que a porcentagem de água armazenada pelo dossel depende da lâmina de água que é aplicada em cada irrigação, além das características da variedade, espaçamento de plantas e índice de área foliar.

Conte \& Leopoldo (1986) estimaram a retenção de água de chuva pela cultura do milho, encontrando, em todo o ciclo da cultura, um valor de interceptação foliar de $52,3 \mathrm{~mm}$, do total precipitado de $646,1 \mathrm{~mm}$, correspondendo a $8,1 \%$. $\mathrm{O}$ escoamento através do colmo, foi de $143,7 \mathrm{~mm}$, correspondendo a $22 \%$. Os autores comentam que o desenvolvimento máximo, em termos de massa foliar, ocorreu entre os $95^{\circ}$ e $105^{\circ}$ dias da cultura, de acordo com suas observações.

Segundo Quinn \& Laften, 1983 e Parkin \& Codling, 1990, cerca de 49\% da lâmina total aplicada foi escoada pelo colmo do milho, estando altamente relacionada com a massa do dossel, podendo decrescer com a duração da chuva.

Valores de retenção foliar de 1,2 e 2,6 mm de água em diferentes fases do ciclo do milho, com diferentes emissores em pivô central, foram encontrados por (Pessoa, 1994). 
Silva et al. (1994) mediram e simularam a interceptação foliar de água na cultura do milho, utilizando um sistema de irrigação por aspersão. Os resultados medidos mostraram que para uma lâmina de água de 453,2mm (precipitações e irrigações), e a interceptação foliar foi de $141,0 \mathrm{~mm}$, correspondendo a $31,11 \%$. Os autores obtiveram valores simulados, de interceptação foliar de 137 e $141 \mathrm{~mm}$, correspondendo a 30,2 e $31,1 \%$, respectivamente, para os modelos potencial e quadrático.

Maddonni \& Otegui (1996), estudando a interceptação da luz pela cultura do milho, citam diversos autores em seu trabalho que observaram correlação da interceptação de luz pela cultura do milho com o índice de área foliar, que pode ser expressa através de função exponencial.

Stone et al. (1994), ao analisarem a distribuição de um inseticida aplicado via pivô central na cultura do milho, observaram que o volume de água coletado aumentou à medida que diminuiu a altura de coletores em relação ao nível do solo, confirmando o efeito "funil" da folhagem do milho.

Follegatti et al. (1998), avaliando a interceptação foliar de lâminas de irrigação aplicadas por aspersão convencional na cultura do milho, encontraram que 44,5 e $50 \%$ da precipitação efetiva alcançaram a superfície do solo via escoamento pelo colmo nas parcelas que receberam água a 3 e $4 \mathrm{~mm} \cdot \mathrm{h}^{-1}$, enquanto na parcela com intensidade de aplicação de $9 \mathrm{~mm} \cdot \mathrm{h}^{-1}$ o escoamento para o colmo foi reduzido para $38,8 \%$. Os autores comentam que o aumento simultâneo do escoamento pelo colmo e da precipitação interna foi devido à diminuição das perdas por interceptação.

Castilho et al. (2000) verificaram que 39,5\% da precipitação total incidente foram interceptados pela cultura de cana-de-açúcar para um IAF de 1,95. Nesse estudo, os autores relatam que houve uma grande variabilidade nas quantidades de precipitações interceptadas, devido às desigualdades de IAF sobre as áreas de coleta. Os autores sugerem que a quantificação da interceptação seja analisada em intervalos menores de medida da precipitação incidente, e que sejam relacionados com os valores de IAF. 
Baseando-se nas informações anteriores, verifica-se que os valores de água interceptados pela cultura de milho são bastante variados, e devem ser determinados para cada "situação específica" no referente a índice de área foliar, espaçamentos, cultivar (arquitetura da planta), para que os fertilizantes aplicados sejam quantificados através do volume de água coletada. Estudos têm mostrado o efeito significativo do dossel na distribuição de água na superficie do solo. Dessa forma, a interceptação tem importância considerável, principalmente quando o alvo da aplicação de agroquímicos via pivô central são as folhas das plantas. 


\section{MATERIAL E MÉTODOS}

\section{1 Área experimental}

O experimento com milho fertirrigado foi implantado em 28 de agosto de 1998 na área experimental de irrigação do Departamento de Produção Vegetal, da Escola Superior de Agricultura "Luiz de Queiroz" (ESALQ) da Universidade de São Paulo (USP), em Piracicaba-SP, situado nas coordenadas geográficas de $22^{\circ} 42^{\prime}$ de latitude sul e $47^{\circ} 38^{\prime}$ de longitude oeste e altitude de $540 \mathrm{~m}$. O clima, conforme classificação de Köppen, é o Cwa, subtropical úmido, com três meses mais secos (junho, julho e agosto), chuvas de verão, seca de inverno, temperatura média do mês mais quente superior a $22^{\circ} \mathrm{C}$, e a do mês mais frio inferior a $18^{\circ} \mathrm{C}$ (Bezerra, 1995).

O solo da área é classificado como Terra Roxa Estruturada eutrófica, horizonte A moderado, textura argilosa (Basanta, 1999).

\subsection{Sistema de irrigação e equipamentos para fertirrigação}

O sistema de irrigação utilizado foi um pivô central de baixa pressão, composto de uma torre, cujas especificações técnicas estão descritas na Tabela 1.

$\mathrm{O}$ equipamento usado para a injeção de fertilizantes foi uma bomba injetora dosificadora INDEK, de capacidade máxima de injeção de $0,920 \mathrm{~m}^{3} \mathrm{~h}^{-1}$, e um reservatório com capacidade para $2,0 \mathrm{~m}^{3} \mathrm{de}$ calda (Tabela 1 ).

O manejo da irrigação baseou-se em três baterias de tensiômetros instalados nas profundidades de 0,20 e $0,40 \mathrm{~m}$ nas entre linhas de plantas. As irrigações 
foram realizadas sempre que potencial matricial se aproximava de $40 \mathrm{kPa}$, na profundidade de $0,20 \mathrm{~m}$.

Tabela 1. Especificações técnicas do equipamento de irrigação e bomba injetora de fertilizantes.

\begin{tabular}{|c|c|c|c|}
\hline \multicolumn{4}{|c|}{ Pivô Central Carborundum MPC 630/01-639/L4 G2S - baixa pressão, 1 torre } \\
\hline \multicolumn{2}{|l|}{ Composição do Pivô } & \multicolumn{2}{|c|}{ Unidade de bombeamento } \\
\hline Comprimento do vão inicial & $61,30 \mathrm{~m}$ & Vazão exigida & $21,35 \mathrm{~m}^{3} \mathrm{~h}^{-1}$ \\
\hline Lance em balanço & $27,97 \mathrm{~m}$ & Pressão exigida & $366 \mathrm{kPa}$ \\
\hline Comprimento total do equipamento & $89,27 \mathrm{~m}$ & \multicolumn{2}{|c|}{ Bomba centrífuga } \\
\hline \multicolumn{2}{|l|}{ Área irrigada } & Marca & ALBRIZZI \\
\hline Alcance efetivo do canhão final & $15,00 \mathrm{~m}$ & Modelo & 3048 \\
\hline Raio efetivo da área irrigada & $104,27 \mathrm{~m}$ & Diâmetro do rotor & $30,48 \mathrm{~mm}$ \\
\hline Área circular irrigada & $34200 \mathrm{~m}^{2}$ & Vazão & $21,35 \mathrm{~m}^{3} \mathrm{~h}^{-1}$ \\
\hline \multicolumn{2}{|l|}{ Características Técnicas } & Pressão & $420 \mathrm{kPa}$ \\
\hline Lâmina bruta a aplicar & $15 \mathrm{~mm} \mathrm{dia}^{-1}$ & Rendimento & $62 \%$ \\
\hline Tempo de operação diário & $24 \mathrm{~h}$ & Rotação & $3450 \mathrm{rpm}$ \\
\hline Vazão necessária & $21,35 \mathrm{~m}^{3} \mathrm{~h}^{-1}$ & Potência absorvida no eixo & $3,94 \mathrm{kw}$ \\
\hline Padrão molhado & $12 \mathrm{~m}$ & Pressão no ponto do pivô & $347 \mathrm{kPa}$ \\
\hline Tempo de molhamento ( $40 \%$ relê) & $0,167 \mathrm{~h}$ & \multirow{2}{*}{\multicolumn{2}{|c|}{\begin{tabular}{|c|} 
Transformador da unidade de bombeamento \\
(Fonte de alimentação trifásica)
\end{tabular}}} \\
\hline Lâmina bruta mínima por volta $100 \%$ & $1,3 \mathrm{~mm} \mathrm{dia}^{-1}$ & & \\
\hline Lâmina bruta por revolução $40 \%$ & $3,0 \mathrm{~mm}$ & Potência & $7,5 \mathrm{kva}$ \\
\hline Tempo de revolução ( $40 \%$ relê) & $5,36 \mathrm{~h}$ & Tensão (trifásica) & $220 v$ \\
\hline Velocidade última torre a $40 \%$ & $72 \mathrm{~m} \mathrm{~h}^{-1}$ & \multicolumn{2}{|c|}{$\begin{array}{r}\text { Motor Elétrico } \\
\end{array}$} \\
\hline \multicolumn{2}{|c|}{ Características da bomba injetora } & Marca & BÚFALO \\
\hline Marca & INDEK & Modelo & IP-54 \\
\hline Modelo & $\mathrm{BP} 2-238$ & Potência nominal & $5,52 \mathrm{kw}$ \\
\hline Pressão de operação & 0 a $1500 \mathrm{kPa}$ & Rotação & $3450 \mathrm{rpm}$ \\
\hline Vazão & a $0,920 \mathrm{~m}^{3} \mathrm{~h}^{-1}$ & Tensão / frequência & $220 \mathrm{v} / 60 \mathrm{~Hz}$ \\
\hline Escala de ajuste do pistão & 15 a $40 \mathrm{~mm}$ & Eficiência & $90 \%$ \\
\hline Volume do tanque (fibra de vidro) & $2,0 \mathrm{~m}^{3}$ & Consumo & $4,37 \mathrm{kwh}$ \\
\hline
\end{tabular}

\begin{tabular}{c|c|c|c|c|c|c}
\hline \multicolumn{7}{c}{ Características dos seis emissores sobre as parcelas } \\
\hline Bocal & Cor & $\begin{array}{c}\text { Diâmetro } \\
(\mathbf{m m})\end{array}$ & Número & $\begin{array}{c}\text { Modelo } \\
\text { NELSON }\end{array}$ & $\begin{array}{c}\mathbf{N}^{\circ} \text { de } \\
\text { ranhuras }\end{array}$ & $\begin{array}{c}\text { Altura do solo } \\
(\mathbf{m})\end{array}$ \\
$14^{\circ}$. & Amarelo & 2,32 & 12 & 9428 NIC 3 & 36 & 2,0 \\
$15^{\circ}$. & Amarelo & 2,48 & 13 & 9428 NIC 1 & 36 & 2,0 \\
$16^{\circ}$. & Verde & 2,74 & 14 & 9428 NIC 1 & 36 & 2,0 \\
$17^{\circ}$. & Verde & 2,74 & 14 & 9428 NIC 1 & 36 & 2,0 \\
$18^{0}$. & Verde & 3,00 & 15 & 9428 NIC 4 & 36 & 2,0 \\
$19^{\circ}$. & Verde & 2,74 & 14 & 9428 NIC 2 & 36 & 2,0 \\
\hline
\end{tabular}




\subsection{Material genético utilizado e tratos culturais}

O híbrido de milho (Zea mays L.) utilizado foi o Cargill 909, semeado no espaçamento de 0,85m entre linhas com 5 plantas por metro linear, ocupando 3/4 da área total do pivô (2,3 ha). Para a adubação de semeadura foram utilizados $50 \mathrm{~kg} \mathrm{ha}^{-1}$ de $\mathrm{K}_{2} \mathrm{O}$,

$80 \mathrm{~kg} \mathrm{ha}^{-1}$ de $\mathrm{P}_{2} \mathrm{O}_{5}$ e $30 \mathrm{~kg} \mathrm{ha}^{-1}$ de $\mathrm{N}$. As sementes foram tratadas com o fungicida thiabendazolle na quantidade de $0,3 \mathrm{~kg}$ de produto comercial por $100 \mathrm{~kg}$ de semente. Para o controle de pragas, utilizaram-se lambda cyalotrin (para lagarta-rosca) e lufenuron e clopyrifos (para a lagarta do cartucho). Para o controle das plantas daninhas foi usado nicosulfuron + bentazon.

\subsection{Coleta de amostras}

Foram delimitadas três parcelas de $95 \mathrm{~m}^{2}$ (formato trapezoidal) compreendidas entre o $14^{\circ}$. e $19^{\circ}$. difusores, distantes $31,5 \mathrm{~m}$ do centro do pivô, paralelas entre si e à lateral do pivô (Figura 1). Dentro de cada parcela foram dispostos os tratamentos (alturas de coletas) com três repetições, de acordo com o número de observações para cada fase de desenvolvimento da cultura do milho.

Baseando-se nas metodologias encontradas nos trabalhos de Steiner et al. (1983), Leopoldo et al. (1981), Conte \& Leopoldo (1986), Silva et al. (1994), Basanta (1999) e em testes preliminares feitos na área, definiu-se a metodologia mais apropriada para a coleta de água e fertilizantes sob a cultura do milho.

Para a determinação da precipitação interna que passava pelo dossel da cultura do milho, construíram-se "piscinas" (reservatórios de água em lona plástica) montadas na base das plantas e suportadas por hastes metálicas e de madeira, compostas por duas partes de formato retangular, semelhantes a duas calhas, uma de cada lado das linhas de semeadura. Para a determinação do volume escoado pelo colmo do milho, instalaram-se coletores plásticos presos ao colmo da cultura. As coletas de amostras de água e fertilizante foram divididas em três épocas ao longo do ciclo da cultura, 
correspondentes aos estádios de desenvolvimentos de 4 folhas (E1), 8 folhas (E2) e 12 folhas (E3).

Para a primeira aplicação de fertilizante, realizada quando a cultura possuía quatro folhas (E1), as plantas estavam muito pequenas, não justificando a instalação de "piscinas" em sua base, nem mesmo a adaptação de coletores em seu colmo, pois a interceptação de água pelo dossel da cultura foi pouco significativa. Para essa fase de quatro folhas, coletaram-se três plantas por parcela antes do pivô passar, e outras três imediatamente após a sua passagem. Antes de cada irrigação, foi necessário retirar plantas de "controle" para a determinação do teor de água, assumindo que no mesmo momento de coleta as plantas tinham o mesmo teor de água. Conhecendo-se o teor de água e a massa de matéria seca da planta, determinou-se a quantidade de água constitutiva. Dessa forma, o volume de água retido pela folhagem foi calculado pela diferença entre a massa de planta irrigada antes da secagem e a massa após a secagem, subtraindo-se o volume de água correspondente à massa de água constitutiva, assumindo a massa específica da água de $1000 \mathrm{~kg} \mathrm{~m}^{-3}$. Wauchope et al. (1997) e Basanta (1999) utilizaram metodologia semelhante para as culturas de milho e algodão, em que as plantas foram pesadas antes e após a irrigação por aspersão.



Figura 1- Localização das parcelas na área experimental. 
O procedimento analítico da metodologia proposta é o seguinte:

a) determinação da massa de água armazenada sobre as folhas das plantas:

$$
\begin{gathered}
\mathrm{m}_{\mathrm{t}}=\mathrm{m}_{\mathrm{wc}}+\mathrm{m}_{\mathrm{s}}+\mathrm{m}_{\mathrm{we}} \\
\mathrm{m}_{\mathrm{we}}=\mathrm{m}_{\mathrm{t}}-\left(\mathrm{m}_{\mathrm{wc}}+\mathrm{m}_{\mathrm{s}}\right) \\
\mathrm{U}=\frac{\mathrm{m}_{\mathrm{wc}}}{\left(\mathrm{m}_{\mathrm{s}}+\mathrm{m}_{\mathrm{wc}}\right)}
\end{gathered}
$$

Sendo assim:

$$
\begin{gathered}
\mathrm{m}_{\mathrm{wc}}=\frac{\mathrm{U} \cdot \mathrm{m}_{\mathrm{s}}}{(1-\mathrm{U})} \\
\mathrm{m}_{\mathrm{we}}=\mathrm{m}_{\mathrm{t}}-\frac{\mathrm{U} \cdot \mathrm{m}_{\mathrm{s}}}{(1-\mathrm{U})}
\end{gathered}
$$

em que $m_{t}$ se refere à massa total da planta antes da secagem $(\mathrm{g}) ; \mathrm{m}_{\mathrm{s}}$ à massa de matéria seca (massa da planta irrigada após a secagem) $(\mathrm{g}) ; \mathrm{m}_{\mathrm{wc}}$ à massa de água constitutiva (g); $\mathrm{m}_{\text {we }}$ à massa de água externa retida na folhagem $(\mathrm{g})$; $\mathrm{U}$ à umidade da planta $\left(\mathrm{g} \mathrm{g}^{-1}\right)$.

b) volume e lâmina de água armazenado na folhagem das plantas:

$$
\begin{gathered}
\rho_{\mathrm{w}}=\frac{\mathrm{m}_{\mathrm{w}}}{\mathrm{V}_{\mathrm{w}}} \\
\mathrm{V}_{\mathrm{w}}=\frac{\mathrm{m}_{\mathrm{w}}}{\rho_{\mathrm{w}}}
\end{gathered}
$$

Sendo assim: 


$$
\begin{gathered}
\mathrm{V}_{\mathrm{w}}=\frac{\mathrm{m}_{\mathrm{t}}}{\rho_{\mathrm{w}}}-\frac{\mathrm{m}_{\mathrm{s}}}{\rho_{\mathrm{w}}} \cdot\left[\frac{1}{(1-\mathrm{U})}\right] \\
\mathrm{h}=\frac{10 \cdot \mathrm{V}_{\mathrm{w}}}{\mathrm{AFT}}-\left(\mathrm{P}_{\mathrm{E}}+\mathrm{P}_{\mathrm{D}}\right)
\end{gathered}
$$

em que h se refere à lâmina de água retida nas folhas da planta $(\mathrm{mm}) ; \rho_{\mathrm{w}}$ à massa específica da água $\left(\mathrm{g} \mathrm{cm}^{-3}\right) ; \mathrm{V}_{\mathrm{w}}$ ao volume de água armazenado nas folhas da planta $\left(\mathrm{cm}^{3}\right.$ planta $\left.{ }^{-1}\right)$; AFT à área foliar total $\left(\mathrm{cm}^{2}\right) ; P_{E}$ às perdas por evaporação $(\mathrm{mm})$ e $P_{D}$ às perdas por deriva $(\mathrm{mm})$.

Para esse estádio de desenvolvimento (E1), h se refere à lâmina de água retida por metro quadrado de folhas ( $\mathrm{L} \mathrm{m}^{-2}$ folhas), e para os dois outros estádios de desenvolvimento (E2) e (E3), INT se refere à lâmina de água retida por metro quadrado de solo ( $\mathrm{L} \mathrm{m}_{\text {solo }}^{-2}$. Portanto, o valor de INT do estádio de desenvolvimento (E1), foi determinado pela equação:

$$
\text { INT }=\text { h.IAF }
$$

em que INT se refere à lâmina de água retida nas folhas da planta $(\mathrm{mm})$ e IAF ao índice de área foliar $\left(\mathrm{m}^{2} \cdot \mathrm{m}^{-2}\right)$.

No estádio de desenvolvimento correspondente a 8 folhas (E2), reservatórios de água em lona plástica, doravante denominados "piscinas", e coletores plásticos com volume de 0,5 litros e área da seção de coleta de $5,03 \times 10^{-3} \mathrm{~m}^{2}$ foram colocados nas alturas de 0,00 e $0,25 \mathrm{~m}$ em relação ao nível do solo. Para coletar a precipitação interna que passava através do dossel da cultura, "piscinas" com dimensões $0,80 \mathrm{~m} \times 0,95 \mathrm{~m}$, foram montadas na base das plantas, sendo suportadas por hastes metálicas e de madeira. Na Figura 2 está esquematizada a instalação de coletores e a 
"piscina" para a altura de coleta de $0,00 \mathrm{~m}$ em relação ao solo. Nas demais alturas amostradas, outras plantas foram utilizadas para a montagem do sistema de coleta.

Para medir o volume de água escoado pelo colmo do milho, foram instalados coletores plásticos (volume de 0,5L) que o envolviam. Para isso, fez-se um corte longitudinal na face lateral do coletor, com uma abertura cilíndrica no fundo, adaptado-o no colmo do milho através de um estrangulamento para obter boa aderência. Depois de feita essa fixação, procedeu-se à vedação com massa de calafetar, na parte inferior do recipiente plástico, para eliminar os possíveis vazamentos.



Figura 2 - Disposição dos coletores e "piscinas" no terço inferior $(0,00 \mathrm{~m})$ da planta de milho.

As "piscinas" foram instaladas nas mesmas alturas dos coletores no colmo e a extração da água dos coletores foi feita por seringas sem agulha, conectandose à sua ponta um microtubo para auxiliar a retirada da água no ponto mais profundo do coletor. $\mathrm{O}$ volume de água coletado foi medido por uma proveta com graduação de $1 \mathrm{ml}$.

Para a terceira etapa, quando as plantas apresentavam 12 folhas (E3), foram instalados os coletores e "piscinas" em três alturas $(0,00,0,50$ e $1,40 \mathrm{~m})$ no colmo em relação ao solo. 
As dimensões das "piscinas" para as épocas de coleta de água na planta correspondente a oito folhas (E2) e a 12 folhas (E3) são apresentadas nas Tabelas 2 e 3. Para todas as instalações nas três parcelas, consideraram-se sempre três repetições.

Tabela 2. Altura das "piscinas", área de coleta e número de plantas dentro de cada "piscina" para a época de coleta (E2).

\begin{tabular}{ccccc}
\hline Parcela & "Piscina" & $\begin{array}{c}\text { Altura } \\
(\mathrm{m})\end{array}$ & $\begin{array}{c}\text { Área de coleta } \\
\left(\mathrm{m}^{2}\right)\end{array}$ & Número plantas \\
\hline P1 & P1- A & 0,00 & 0,670 & 6 \\
& P1- B & 0,25 & 0,720 & 5 \\
\hline P2 & P2-A & 0,00 & 0,618 & 5 \\
& P2-B & 0,25 & 0,720 & 5 \\
\hline P3 & P3-A & 0,00 & 0,640 & 6 \\
& P3- B & 0,25 & 0,720 & 5 \\
\hline
\end{tabular}

Tabela 3. Altura das "piscinas", área de coleta e número de plantas dentro de cada "piscina" para a época de coleta (E3).

\begin{tabular}{ccccc}
\hline Parcela & "Piscina" & $\begin{array}{c}\text { Altura } \\
(\mathrm{m})\end{array}$ & $\begin{array}{c}\text { Área de coleta } \\
\left(\mathrm{m}^{2}\right)\end{array}$ & Número plantas \\
\hline \multirow{2}{*}{ P1 } & P1-A & 0,00 & 0,660 & 6 \\
& P1- B & 0,50 & 0,612 & 4 \\
& P1-C & 1,40 & 0,649 & 5 \\
\hline \multirow{2}{*}{ P2 } & P2-A & 0,00 & 0,618 & 5 \\
& P2-B & 0,50 & 0,640 & 5 \\
& P2-C & 1,40 & 0,629 & 4 \\
\hline \multirow{2}{*}{ P3 } & P3-A & 0,00 & 0,640 & 6 \\
& P3- B & 0,50 & 0,435 & 5 \\
& P3-C & 1,40 & 0,589 & 5 \\
\hline
\end{tabular}

Nas Figuras 2, 3 e 4 observam-se as instalações das "piscinas" e coletores fixados ao colmo, em uma mesma altura em relação ao solo, em plantas diferentes, representando uma faixa de área foliar, a qual interceptaria a água aplicada via pivô acima de cada altura estabelecida. Uma vista geral das instalações das "piscinas", coletores e estrutura de coleta nas alturas consideradas podem ser vistas nas Figuras 5, 6, e 7 . 




Figura 3 - Disposição dos coletores e "piscinas" no terço médio $(0,50 \mathrm{~m})$ da planta de milho.

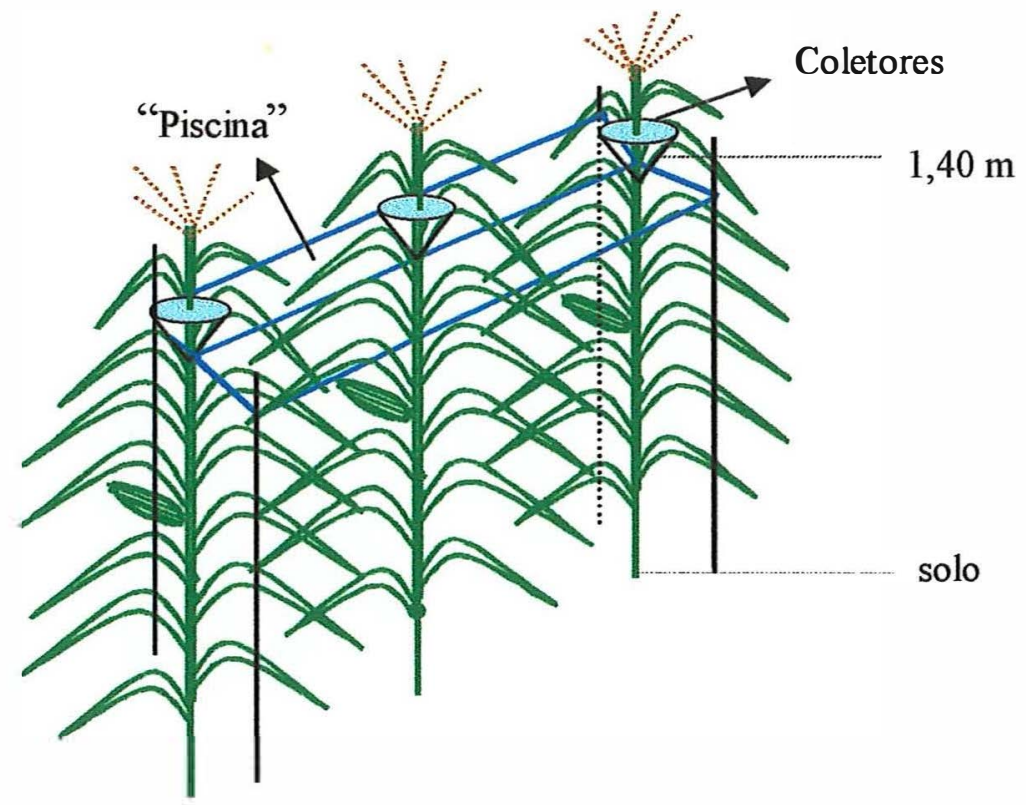

Figura 4 - Disposição dos coletores e "piscinas" no terço superior $(1,40 \mathrm{~m})$ da planta de milho. 


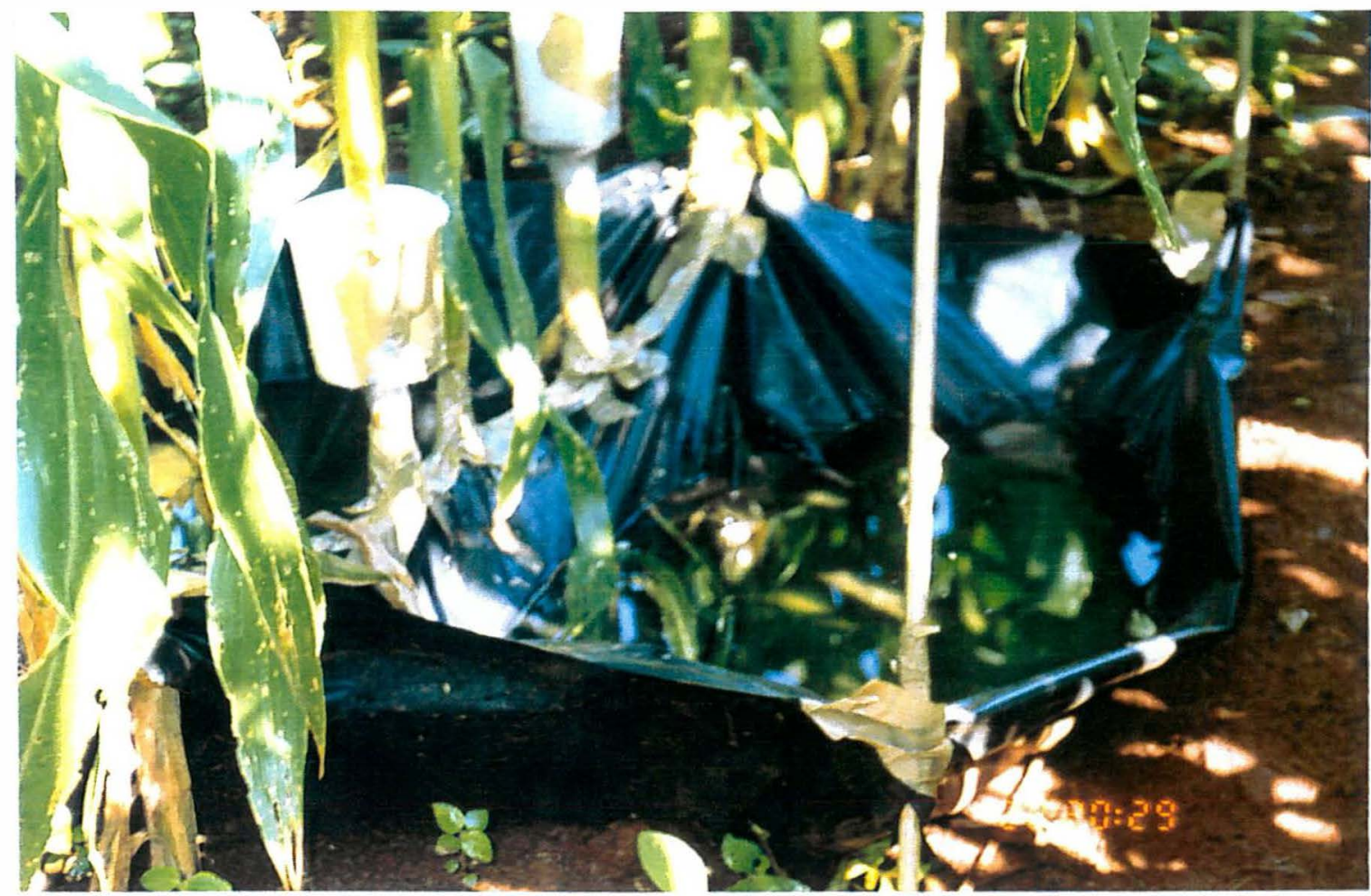

Figura 5 - Vista geral da "piscina" e coletores instalados na cultura do milho, na altura de coleta de $0,00 \mathrm{~m}$ em relação ao solo.

Nas segunda e terceira etapas, por estar o milho numa fase de desenvolvimento mais avançada, foi aberta uma área no local de semeadura, paralela à lateral do pivô, para que os seis emissores que passavam sobre dossel das parcelas fossem avaliados.

A uniformidade de distribuição de água e fertilizante foi determinada nesta área livre de plantas, ao lado e próxima às parcelas, sob os mesmos difusores. Os volumes de água precipitados nos coletores e "piscinas" foram devidamente separados e identificados por parcela e altura de amostragem (cota) para que, posteriormente, fossem determinadas as condutividades elétricas em laboratório. De posse da condutividade elétrica $\left(\mathrm{dS} \mathrm{\textrm {m } ^ { - 1 } )}\right.$ da água de irrigação, determinou-se, por equações ajustadas, a concentração do produto $\left(\mathrm{g} \mathrm{L}^{-1}\right)$ aplicado via água de irrigação. 


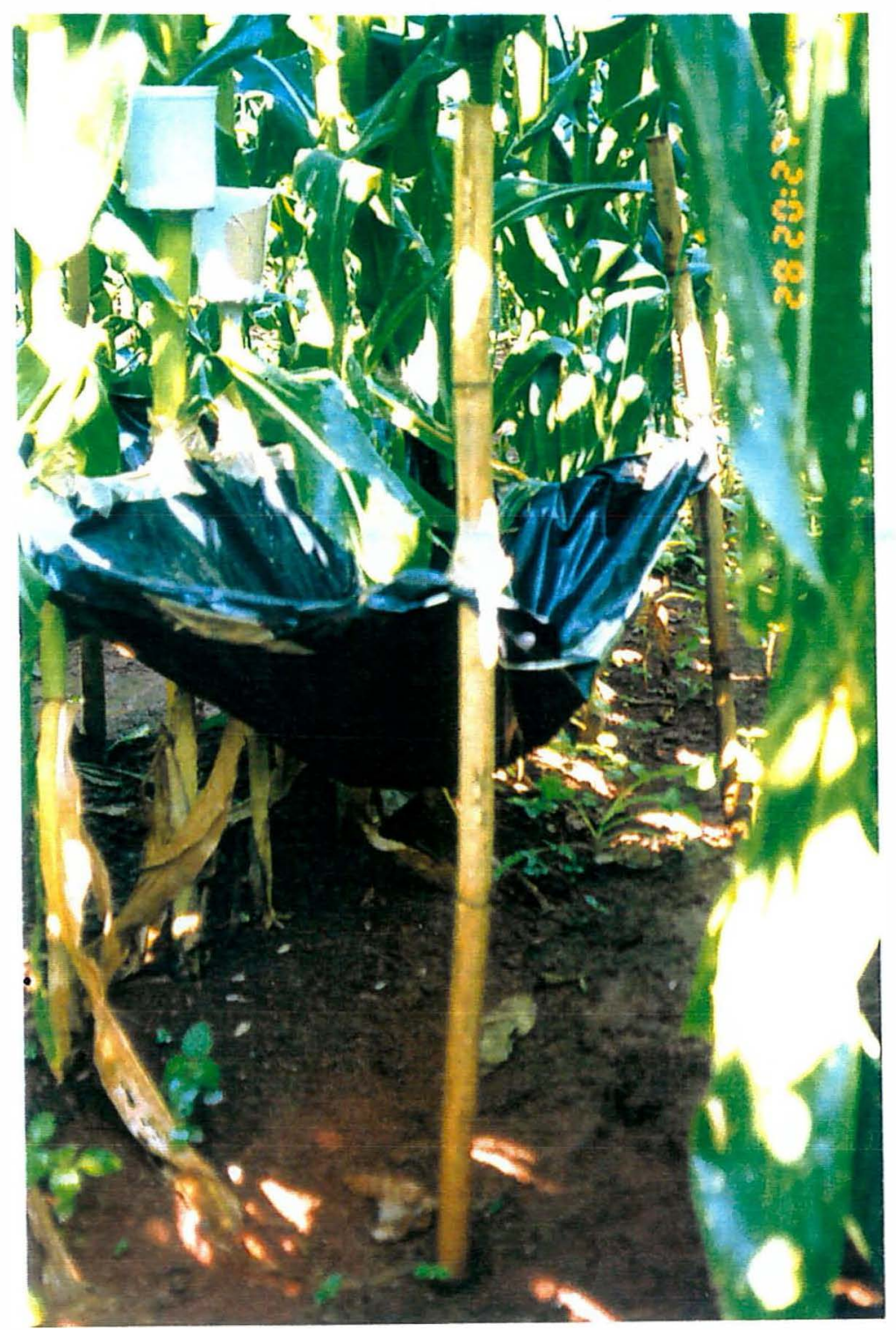

Figura 6 - Vista geral da "piscina" e coletores instalados na cultura do milho, na altura de coleta de $0,50 \mathrm{~m}$ em relação ao solo. 


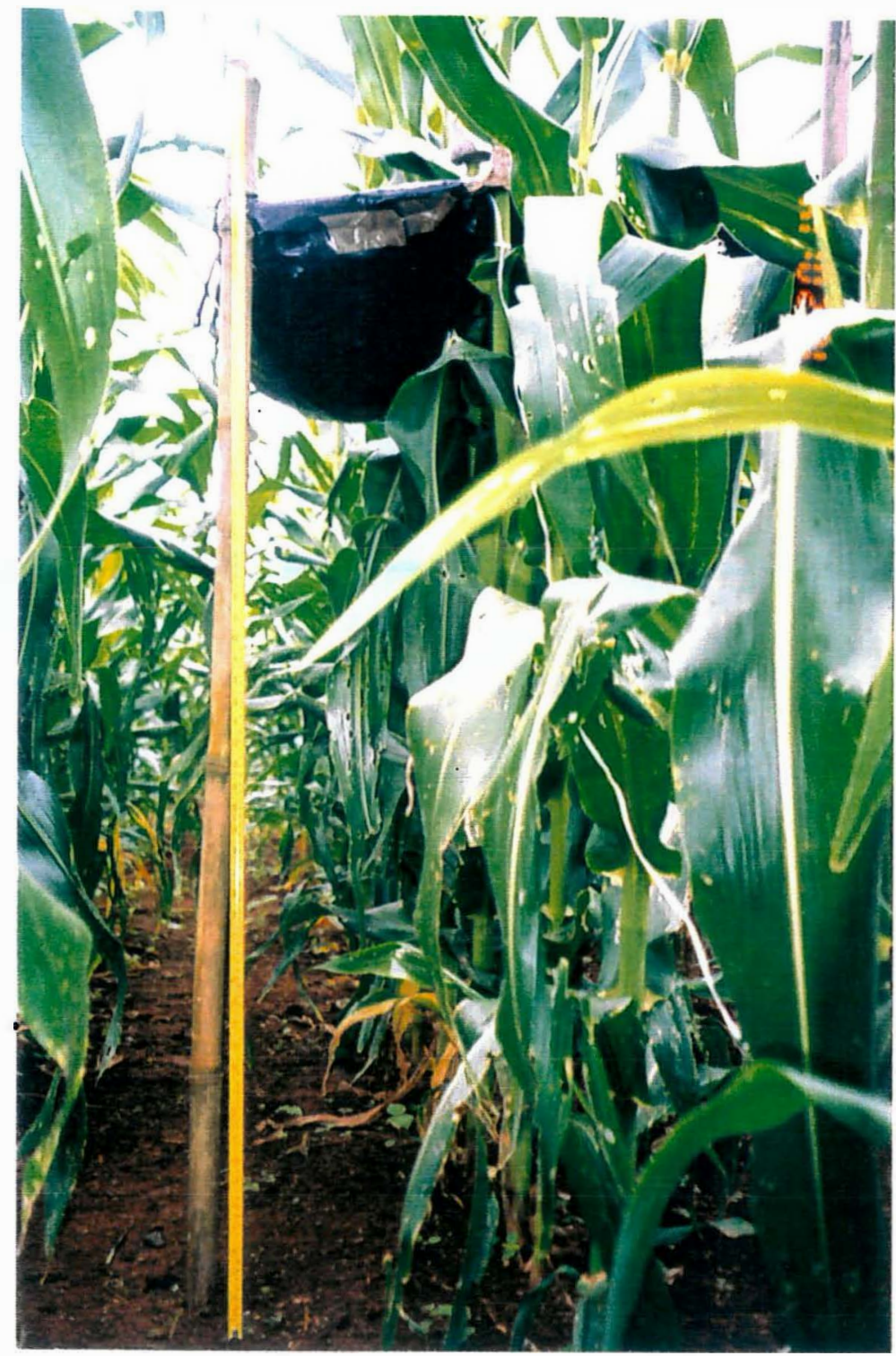

Figura 7 - Vista geral da "piscina" e coletores instalados na cultura do milho, na altura de coleta de $1,40 \mathrm{~m}$ em relação ao solo. 
A quantidade de $\mathrm{N}$ e $\mathrm{K}_{2} \mathrm{O}$ na água de irrigação em $\left(\mathrm{kg} \mathrm{ha}^{-1}\right)$ foi calculada pela equação:

$$
\mathrm{Qp}=10 . \mathrm{C}_{\mathrm{p}} \mathrm{I} \text {. }
$$

em que Qp se refere à quantidade de $\mathrm{N}$ e/ou $\mathrm{K}_{2} \mathrm{O}\left(\mathrm{kg} \mathrm{ha}^{-1}\right) ; \mathrm{C}_{\mathrm{P}}$ à concentração de $\mathrm{N}$ e/ou $\mathrm{K}_{2} \mathrm{O}\left(\mathrm{g} \mathrm{L}^{-1}\right)$; I à lâmina média aplicada $(\mathrm{mm})$.

As perdas por interceptação foliar para as épocas de coleta correspondentes a 8 folhas (E2) e a 12 folhas (E3) foram calculadas pela equação:

$$
I N T=P_{T}-\left(P_{I}+E_{C}+P_{E}+P_{D}\right)
$$

em que INT se refere à interceptação foliar $(\mathrm{mm}) ; \mathrm{P}_{\mathrm{T}}$ à precipitação total $(\mathrm{mm}) ; \mathrm{P}_{\mathrm{I}}$ à precipitação interna $(\mathrm{mm})$; Ec ao escoamento pelo colmo $(\mathrm{mm})$; $\mathrm{P}_{\mathrm{E}}$ às perdas por evaporação $(\mathrm{mm})$ e $P_{D}$ às perdas por deriva $(\mathrm{mm})$. Os valores de $P_{E}$ e $P_{D}$ foram considerados nulos, em razão das condições climáticas favoráveis no momento das avaliações (Tabela 21 - anexo).

A área foliar da cultura foi determinada selecionando-se três plantas de cada parcela, com características semelhantes às plantas utilizadas para quantificar os volumes de água retidos nas diferentes alturas de coleta. A área foliar foi determinada com o medidor LICOR, modelo LI 3100. Posteriormente, calculou-se o índice de área foliar médio nos diferentes estádios de desenvolvimento da cultura.

\subsection{Uniformidade de distribuição de água e fertilizantes}

A uniformidade de distribuição de água do pivô foi determinada de acordo com as normas da ABNT (1985). Tal metodologia consiste em coletar as 
precipitações em coletores distribuídos em espaçamentos eqüidistantes, em duas linhas radiais, formando entre si um ângulo de $3^{\circ}$.

Foram instalados 21 coletores espaçados de 5 metros a uma altura de $0,50 \mathrm{~m}$ em relação ao solo, com uma área de captação de $5,03 \times 10^{-3} \mathrm{~m}^{2}$. O volume coletado correspondeu à média dos dois coletores instalados à mesma distância do centro do pivô nas duas linhas radiais de cada posição.

Para a determinação do Coeficiente de Uniformidade de Christiansen (CUC), adotou-se a equação proposta por Heermann \& Hein (1968).

Simultaneamente, objetivando avaliar os emissores que irrigavam a área das parcelas, delimitou-se uma área de $12 \times 8 \mathrm{~m}$ paralela às parcelas e também à lateral do pivô, sob os seis emissores que passavam sobre o dossel das plantas analisadas. Dessa forma, as parcelas paralelas (P1, P2 e P3) entre si e a área delimitada, receberam a lâmina de água aplicada pelos mesmos difusores. A disposição dos coletores, nessa área, foi de forma retangular, distribuídos em três linhas paralelas, contendo 10 coletores por linha, espaçados de $0,50 \times 0,50 \mathrm{~m}$. Todas as avaliações foram feitas aproximadamente às 6:30h para reduzir os efeitos de ventos sobre a área irrigada. As avaliações foram realizadas com o equipamento a uma velocidade de $72 \mathrm{~m} \mathrm{~h}^{-1}$ na sua única torre $(61,3 \mathrm{~m})$, com relê percentual ajustado a $40 \%$. O tempo de avaliação em cada teste foi de aproximadamente 1,5 horas. A avaliação da uniformidade de distribuição de fertilizante via água de irrigação foi realizada simultaneamente, na mesma área de coleta, medindose a condutividade elétrica da água.

\subsection{Aplicação de fertilizantes via fertirrigação na cultura do milho}

A aplicação de fertilizantes foi feita por uma bomba injetora de fertilizantes INDEK (Figura 8). Com intuito de aferir a vazão de injeção com os dados do fabricante, realizou-se um teste de vazão de injeção para as diversas regulagens do curso do pistão. 
Para a aplicação de fertilizantes na água de irrigação, ajustou-se a regulagem do pistão da bomba em $15 \mathrm{~mm}$, de forma a fornecer uma taxa de injeção de $0,3 \mathrm{~m}^{3} \mathrm{~h}^{-1}$ no centro do pivô.

Segundo Costa et al. (1994), a taxa de injeção de um determinado produto químico na lateral de um pivô central foi calculada por:

$$
q_{i}=\frac{P_{d} \cdot r^{2} \cdot V_{T} \cdot V_{a}}{2000 \cdot r_{T} \cdot Q_{p}}
$$

em que $q_{i}$ se refere à taxa de injeção $\left(\mathrm{L} \mathrm{min}^{-1}\right) ; \mathrm{P}_{\mathrm{d}}$ à dose do produto $\left(\mathrm{kg} \mathrm{ha}^{-1}\right) ; \mathrm{r}$ ao raio do pivô $(\mathrm{m}) ; \mathrm{v}_{\mathrm{T}}$ à velocidade da última torre $\left(\mathrm{m} \mathrm{min}^{-1}\right) ; \mathrm{V}_{\mathrm{a}}$ ao volume de água no tanque $(\mathrm{L}) ; \mathrm{r}_{\mathrm{t}}$ à distância do ponto do pivô a última torre $(\mathrm{m})$ e $\mathrm{Q}_{\mathrm{p}}$ à quantidade do produto no tanque (kg ou L)

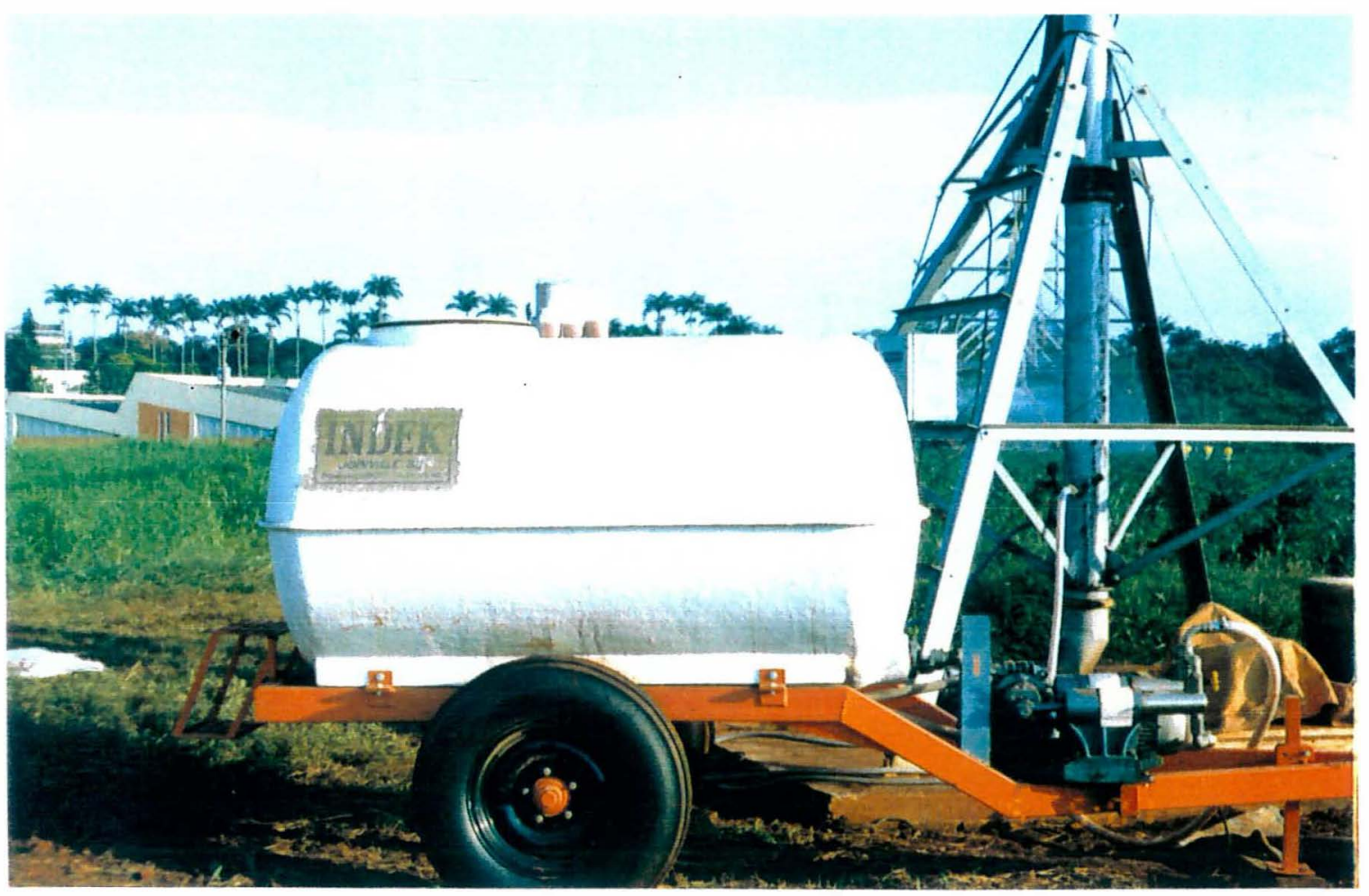

Figura 8 - Tanque e bomba injetora de fertilizantes instalados no centro do pivô. 
O cálculo da concentração do produto na água de irrigação foi determinado por:

$$
C_{a}=\frac{q_{i} \cdot\left(\frac{Q_{p}}{V_{a}}\right)}{60 . Q} \cdot 10^{6}
$$

em que $\mathrm{C}_{\mathrm{a}}$ se refere à concentração do produto na água de irrigação $\left(\mathrm{mg} \mathrm{L}^{-1}\right)$ e $\mathrm{Q}$ à vazão do sistema de irrigação $\left(\mathrm{L} \mathrm{s}^{-1}\right)$.

Os fertilizantes utilizados na fertirrigação foram o sulfato de amônio $\left(\left(\mathrm{NH}_{4}\right)_{2} \mathrm{SO}_{4}\right)$ e o cloreto de potássio $(\mathrm{KCl})$. A distribuição de fertilizante na cultura do milho foi dividida na semeadura e em três aplicações nas fases de desenvolvimento $(4,8$ e 12 folhas) do milho, conforme a Tabela 4.

Tabela 4. Épocas e quantidades de fertilizantes aplicadas na semeadura e nas três fases de desenvolvimento da cultura do milho analisadas.

\begin{tabular}{ccc}
\hline Épocas & $\begin{array}{c}\text { Nitrogênio } \\
\left(\mathrm{kg} \mathrm{ha}^{-1}\right)\end{array}$ & $\begin{array}{c}\text { Potássio } \\
\left(\mathrm{kg} \mathrm{ha}^{-1}\right)\end{array}$ \\
\hline Semeadura & 30 & 40 \\
\hline E1 (4 folhas) & $7+13$ & $7+13$ \\
E2 (8 folhas) & $14+26$ & $7+13$ \\
E3 (12 folhas) & $20+20$ & $5+5$ \\
\hline Total & 130 & 90 \\
\hline
\end{tabular}
E1 - Primeira época de aplicação
E2 - Segunda época de aplicação
E3 - Terceira época de aplicação 
As aplicações necessitaram de três dias para serem realizadas em cada época de aplicação E1, E2 e E3 (Tabela 4). Para a primeira época (E1), correspondente ao estádio de desenvolvimento de 4 folhas, aplicou-se no primeiro dia somente o nitrogênio $\left(7 \mathrm{~kg} \mathrm{ha}^{-1}\right)$; no segundo, somente o potássio $\left(7 \mathrm{~kg} \mathrm{ha}^{-1}\right)$; e no terceiro dia, $\mathrm{N}+\mathrm{K}_{2} \mathrm{O}$ juntos $\left(13 \mathrm{~kg} \mathrm{~N} \mathrm{ha}^{-1}+13 \mathrm{~kg} \mathrm{~K}_{2} \mathrm{O} \mathrm{ha}{ }^{-1}\right)$. Este procedimento teve como objetivo quantificar a porcentagem de $\mathrm{N}$ e $\mathrm{K}_{2} \mathrm{O}$ interceptados pela cultura do milho, separadamente, nas duas primeiras aplicações, e numa terceira aplicação da época (E1) os dois fertilizantes juntos $\left(\mathrm{N}+\mathrm{K}_{2} \mathrm{O}\right)$. Para a segunda época de aplicação (E2), correspondente ao estádio de desenvolvimento de 8 folhas, aplicou-se no primeiro dia somente o nitrogênio $\left(14 \mathrm{~kg} \mathrm{ha}^{-1}\right)$; no segundo, somente o potássio $\left(7 \mathrm{~kg} \mathrm{ha}^{-1}\right)$; e no terceiro dia $\mathrm{N}+\mathrm{K}_{2} \mathrm{O}$ juntos $\left(26 \mathrm{~kg} \mathrm{~N} \mathrm{ha}^{-1}+13 \mathrm{~kg} \mathrm{~K}_{2} \mathrm{O} \cdot \mathrm{ha}^{-1}\right)$. Para a terceira época de aplicação (E3), correspondente ao estádio de desenvolvimento de 12 folhas, aplicou-se no primeiro dia o nitrogênio $\left(20 \mathrm{~kg} \mathrm{ha}^{-1}\right)$; no segundo, o potássio $\left(5 \mathrm{~kg} \mathrm{ha}^{-1}\right)$; e no terceiro dia, $\mathrm{N}+\mathrm{K}_{2} \mathrm{O}$ juntos $\left(20 \mathrm{kgN} \mathrm{ha}^{-1}+5 \mathrm{~kg} \mathrm{~K}_{2} \mathrm{O} \mathrm{ha}{ }^{-1}\right)$.

Para a análise das concentrações de fertilizantes na água de irrigação, determinaram-se em laboratório as suas condutividades elétricas.

\subsection{Curvas de calibração de condutividade elétrica em função da concentração de fertilizante na água de irrigação}

Foram ajustadas curvas de calibração de condutividade elétrica $\mathrm{CEa}$ $\left(\mathrm{dS} \mathrm{m} \mathrm{m}^{-1}\right)$ da água de irrigação em função da concentração de produto $\left(\mathrm{N}\right.$ e $\left.\mathrm{K}_{2} \mathrm{O}-\mathrm{g} \mathrm{L}^{-1}\right)$. Amostras das caldas de injeção de fertilizante foram utilizadas para a confecção das curvas de ajustes. De posse das amostras de caldas, foram feitas diluições até valores próximos aos encontrados na água de irrigação, garantindo, dessa forma, que o valor amostrado na água de irrigação pertencesse a um ponto intermediário da curva.

Caldas semelhantes às formuladas no campo foram feitas em laboratório em proporções menores, formuladas em um volume fixo de 0,2 litros e quantidade de soluto de cada fertilizante proporcional ao diluído no tanque de fertilizante. 
As concentrações $\left(\mathrm{g} \mathrm{L}^{-1}\right)$ de nitrogênio $(\mathrm{N})$ e potássio $\left(\mathrm{K}_{2} \mathrm{O}\right)$ foram determinadas pelas equações 16 e 17. Para a determinação da concentração de $\mathrm{N}$ mais $\mathrm{K}_{2} \mathrm{O}$ juntos, calculou-se, separadamente, cada correspondente e somaram-se os dois para a obtenção da concentração total $\left(\mathrm{C}_{\mathrm{NK}}, \mathrm{g} \mathrm{L}^{-1}\right)$ :

$$
\begin{aligned}
& C_{N}=\frac{g_{\text {soluto }}}{v_{\text {solução }}} \cdot N \\
& C_{K}=\frac{g_{\text {soluto }}}{v_{\text {solução }}} \cdot K
\end{aligned}
$$

em que $\mathrm{C}_{\mathrm{N}}$ se refere à concentração de $\mathrm{N}\left(\mathrm{g} \mathrm{L}^{-1}\right) ; \mathrm{C}_{\mathrm{K}}$ à concentração de $\mathrm{K}_{2} \mathrm{O}\left(\mathrm{g} \mathrm{L}^{-1}\right)$; gsoluto à quantidade de fertilizante adicionado à solução $(\mathrm{g})$; $\mathbf{v}_{\text {solução }}$ ao volume de solução (L); $\mathrm{N}$ à proporção de $\mathrm{N}$ no sulfato de amônio (decimal); $\mathrm{K}$ à proporção de $\mathrm{K}_{2} \mathrm{O}$ no cloreto de potássio (decimal).

\subsection{Delineamento estatístico}

Foram comparados os dados das partições em precipitação interna (PI), escoamento pelo colmo $(\mathrm{Ec})$ e interceptação foliar (INT) em relação à precipitação total $(\mathrm{PT}=100 \%)$ aplicada via pivô central, bem como as concentrações de $\mathrm{N}$ e $\mathrm{K}_{2} \mathrm{O}$ encontradas na água de irrigação.

Utilizou-se um delineamento inteiramente casualizado, em que as variáveis analisadas durante o desenvolvimento da cultura aumentavam em razão do crescimento da planta, possibilitando a inclusão de novos pontos (alturas) de coleta para as fases mais desenvolvidas. No estádio de desenvolvimento correspondente a 4 folhas (E1), não foi possível analisar a interceptação de água na planta em diferentes alturas em relação ao solo, em razão de seu pequeno porte. Para o estádio de desenvolvimento correspondente a 8 folhas (E2), foram analisadas duas alturas na planta em relação ao 
solo foram analisadas $(0,00$ e $0,25 \mathrm{~m})$, podendo, a partir desta época, além da interceptação (INT), adicionar as variáveis precipitação interna (PI) e escoamento pelo colmo (Ec). No último estádio de desenvolvimento correspondente a 12 folhas (E3) foi possível coletar os volumes de água em três alturas na planta $(0,00,0,50$ e 1,40m).

Para a análise de variância, o modelo matemático adotado foi o seguinte:

$$
Y_{i j}=\mu+\tau_{i}+\varepsilon_{i j}
$$

em que o índice i se refere ao número de ordem dos tratamentos ( $\mathrm{i}=1$ a 3 ), $\mathrm{j}$ ao número de ordem das repetições $(j=1$ a 9$), \mu$ à média geral do experimento, $\tau_{i}$ ao efeito do i-ésimo tratamento e $\varepsilon_{\mathrm{ij}}$ ao erro experimental associado ao valor observado $Y_{\mathrm{ij}}$.

$\mathrm{O}$ esquema da análise de variância para esse modelo está descrito na Tabela 5.

Tabela 5. Esquema da análise de variância utilizado para avaliar a retenção da lâmina de água e fertilizantes no dossel das plantas.

\begin{tabular}{lcccc}
\hline Causa de variação & GL & S.Q & Q.M & F \\
\hline Tratamentos & I -1 & SQT & SQT / (I-1) & QMT/QMR \\
Resíduo & I (J-1) & SQR & SQR / (I(J-1)) & \\
\hline Total & IJ -1 & SQ Total & & \\
\hline
\end{tabular}

A análise dos dados foi dividida em três fases F1, F2 e F3. Na primeira (F1) foram comparados os dados referentes às três fases de desenvolvimento $(4,8$ e 12 folhas); na segunda fase (F2) analisou-se o estádio de desenvolvimento correspondente a 8 folhas; e na terceira fase (F3) o estádio de desenvolvimento de 12 folhas.

Para a primeira fase (F1), foram comparados os dados de índice de área foliar (IAF), interceptação de água pelo dossel (INT), concentração de nitrogênio $\left(\mathrm{C}_{\mathrm{N}}\right)$, concentração de potássio $\left(\mathrm{C}_{\mathrm{K}}\right)$ e concentração de nitrogênio mais potássio $\left(\mathrm{C}_{\mathrm{NK}}\right)$, nos três 
estádios de desenvolvimento considerados ( 4,8 e 12 folhas), com três repetições por parcela, totalizando 27 pontos amostrados.

Na segunda fase (F2) foram analisados além, de IAF, INT, $C_{N}, C_{K}$ e $C_{N K}$, os dados de precipitação interna (PI) e escoamento pelo colmo (Ec) no estádio de desenvolvimento de 8 folhas. Nessa fase, consideraram-se duas alturas de coleta $(0,00 \mathrm{e}$ $0,25 \mathrm{~m}$ ) na planta, tendo três repetições por parcela, totalizando 18 pontos amostrados.

Para a terceira fase (F3) analisaram-se as mesmas variáveis da segunda, porém, três alturas de coleta na planta $(0,00,0,50$ e $1,40 \mathrm{~m})$ foram consideradas para esse estádio de desenvolvimento de 12 folhas. Para essa fase, 27 pontos foram amostrados e mantendo-se também três repetições.

\subsection{Desenvolvimento relativo da cultura}

Foram calculados os valores de graus-dia acumulados para cada estádio, utilizando as temperaturas basais mínima e máxima de $10{ }^{\circ} \mathrm{C}(\mathrm{Tb})$ e $30^{\circ} \mathrm{C}(\mathrm{Tm})$, respectivamente. $\mathrm{O}$ desenvolvimento relativo $(\mathrm{Dr})$ foi calculado na fase de florescimento da cultura (máxima área foliar), dividindo a soma calórica acumulada até a data correspondente a cada estádio fenológico pela soma calórica total (índice térmico, IT) no ponto de florescimento.

O desenvolvimento relativo da cultura foi calculado pela seguinte equação:

$$
\operatorname{Dr}_{n}=\frac{\sum_{i=1}^{n}\left(T_{i}-T_{b}\right)}{I T},\left(T_{b} \leq T_{i} \leq T_{m}\right)
$$

em que $\operatorname{Dr}_{n}$ se refere ao estádio de desenvolvimento relativo da cultura até o n-ésimo dia após emergência $\left(0 \leq \mathrm{Dr}_{\mathrm{n}} \leq 1\right)$; Ti à temperatura média $\left({ }^{\circ} \mathrm{C}\right)$ do ar no i-ésimo dia após a emergência; $\mathrm{Tb}$ à temperatura basal mínima da cultura $\left(10^{\circ} \mathrm{C}\right)$; IT ao índice térmico da cultura desde a emergência até o ponto de maturidade fisiológica; Tm à temperatura basal máxima da cultura $\left(30^{\circ} \mathrm{C}\right)$. 


\subsection{Modelos}

Com a finalidade de utilização prática, foram propostos modelos correlacionando a interceptação foliar da lâmina aplicada (INT), quantidades de nitrogênio $\left(\mathrm{Q}_{\mathrm{N}}\right)$ e potássio $\left(\mathrm{Q}_{\mathrm{K}}\right)$ contidos na água de irrigação em função do desenvolvimento relativo da cultura (Dr) e do índice de área foliar (IAF).

Os modelos foram processados através do software TABLE CURVE 2D (Jandel, 1992), obtendo a equação mais representativa para as variáveis correlacionadas.

Os modelos propostos, para fins de manejo, correlacionaram o índice de área foliar (IAF) com as variáveis INT $(\mathrm{mm})$, $\mathrm{Q}_{\mathrm{N}}$ e $\mathrm{Q}_{\mathrm{K}}\left(\mathrm{t} \mathrm{ha}^{-1}\right)$. Para fins de planejamento, os modelos propostos correlacionaram o desenvolvimento relativo (Dr) com as variáveis INT $(\mathrm{mm}), \mathrm{Q}_{\mathrm{N}} \mathrm{e} \mathrm{Q}_{\mathrm{K}}\left(\mathrm{t} \mathrm{ha}{ }^{-1}\right)$.

Para os efeitos de planejamento ou de manejo, com os modelos propostos, podem-se estimar a lâmina interceptada, a quantidade de nitrogênio e de potássio retidas no dossel da cultura, para um determinado desenvolvimento relativo ou índice de área foliar.

Os dados de entrada foram referentes as três épocas de aplicação 4, 8 e 12 folhas (E1, E2 e E3) correlacionando os valores observados de quantidade de produto $\mathrm{N}$ e $\mathrm{K}_{2} \mathrm{O}\left(\mathrm{t} \mathrm{ha}^{-1}\right)$ e lâmina interceptada (INT, $\mathrm{mm}$ ), com o índice de área foliar (IAF, $\mathrm{m}^{2} \mathrm{~m}^{-2}$ ) e desenvolvimento relativo (Dr). 


\section{RESULTADOS}

\subsection{Uniformidade de distribuição de água e fertilizante}

Na Figura 9 observa-se o perfil de distribuição de água aplicada pelo pivô central com uma lâmina média de $3,0 \mathrm{~mm}$, operando a uma pressão de $350 \mathrm{kPa}$ e vazão de $19,46 \mathrm{~m}^{3} \mathrm{~h}^{-1}$. Os valores de Coeficiente de Uniformidade de Christiansen (CUC) para a água e para a calda de fertilizantes foram 82 e $80,5 \%$, respectivamente. De fato, estes valores confirmam a proximidade entre uniformidade de distribuição de água e produto químico, devido ao regime turbulento (Dourado Neto \& Fancelli, 1999). Os valores médios da lâmina avaliada na malha de $0,5 \times 0,5 \mathrm{~m}$ são apresentados na Tabela 22 (anexo).

Os resultados das vazões da bomba injetora Indek, para as diferentes regulagens do curso do pistão, são apresentados na Figura 10.

A Figura 25 (anexo) representa graficamente a variação do potencial matricial da água nas profundidades 0,20 e $0,40 \mathrm{~m}$ no solo, durante ciclo da cultura de milho.

\subsection{Lâmina de água retida nas plantas}

Para a época de coleta de 4 folhas (El), não foi possível a instalação de coletores e "piscinas" nas plantas, em razão da fragilidade de sustentação dos colmos e do pequeno porte do milho. Nesta época, a metodologia adotada baseou-se nos trabalhos de Wauchope et al. (1997) e Basanta (1999). Em função da estrutura da planta nesta 
fase de desenvolvimento, as variáveis precipitação interna (PI) e escoamento pelo colmo (Ec) não foram determinadas. Os dados médios coletados são apresentados na Tabela 6.

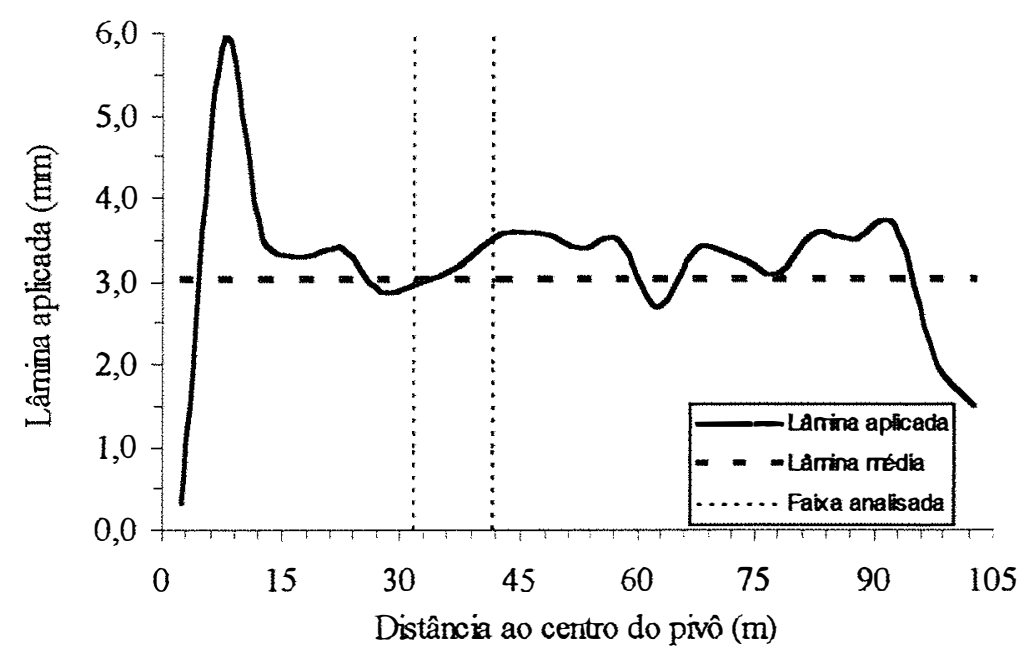

Figura 9 - Perfil de precipitação ao longo da lateral com o sistema operando a $40 \%$ da velocidade máxima.

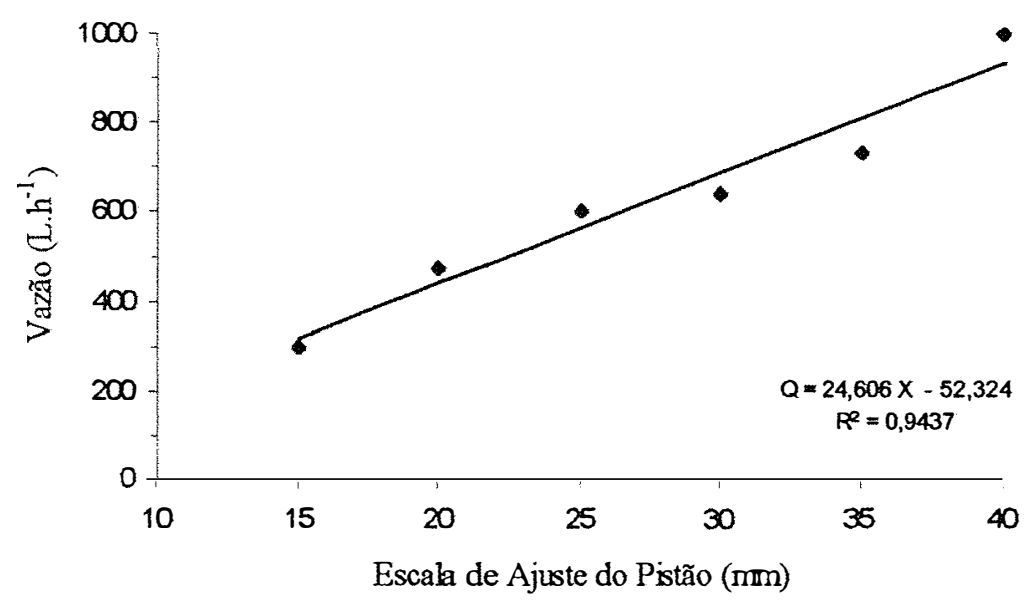

Figura 10 - Curva de ajuste de vazão $\left(\mathrm{L} \mathrm{h}^{-1}\right)$ da bomba injetora de fertilizantes para diferentes regulagens do pistão $(\mathrm{mm})$. 
Tabela 6. Valores médios de lâminas interceptadas (INT) em relação à precipitação total aplicada via pivô central e índice de área foliar (IAF), coletados na planta para a época (E1).

\begin{tabular}{ccccc}
\hline Data & $\begin{array}{c}\mathrm{PT} \\
(\mathrm{mm})\end{array}$ & $\begin{array}{c}\mathrm{h}^{*} \\
(\mathrm{~mm})\end{array}$ & $\begin{array}{c}\mathrm{IAF} \\
\left(\mathrm{m}^{2} \mathrm{~m}^{-2}\right)\end{array}$ & $\begin{array}{c}\mathrm{INT}^{* *} \\
(\mathrm{~mm})\end{array}$ \\
\hline $02 /$ out & 3,0 & 0,195 & 0,263 & 0,051 \\
\hline 03/out & 3,0 & 0,198 & 0,277 & 0,055 \\
\hline $04 /$ out & 3,0 & 0,194 & 0,317 & 0,061 \\
\hline Média & 3,0 & 0,196 & 0,286 & 0,056 \\
\hline
\end{tabular}

$* \mathrm{~h}-\left(\mathrm{L} \mathrm{m}_{\text {folhas }}^{-2}\right)$

** INT $-\left(\mathrm{L} \mathrm{m}^{-2}{ }_{\text {solo }}\right)$

Para a época (E1), com o milho na fase de 4 folhas, verificou-se um valor médio de lâmina interceptada de $0,056 \mathrm{~mm}$ de um total de $3,0 \mathrm{~mm}$ aplicados. A interceptação da lâmina pelo dossel da cultura de milho representou 1,87 \% da lâmina total aplicada. Valores inferiores, para a mesma fase de desenvolvimento do milho, foram observados por Basanta (1999) em razão, provavelmente, da metodologia utilizada, densidade de plantio e lâmina aplicada. Valores próximos de interceptação de água pela cultura do milho foram verificados nos trabalhos de Haynes (1940), Steiner et al. (1983), Conte \& Leopoldo (1986) e Silva et al. (1994). No entanto, nesses estudos, todas as avaliações foram realizadas nos estádios mais desenvolvidos da cultura do milho, com IAF superior a 3, não havendo observações para as fases mais jovens da cultura.

Para a época de amostragem (E2), no estádio fenológico de 8 folhas, foram analisados os valores de INT, Ec e PI para duas alturas de coleta $(0,00$ e $0,25 \mathrm{~m})$ no milho. Os valores médios observados das partições em precipitação interna (PI), escoamento pelo colmo (Ec) e interceptação foliar (INT) em relação à precipitação total aplicada via pivô central, para as alturas de coletas de 0,00 e 0,25m e índices de área foliar durante o desenvolvimento da cultura são apresentados na Tabela 7. Os valores 
médios de PI de 85,57 e $88,31 \%$ foram encontrados para as alturas de coletas de 0,00 e $0,25 \mathrm{~m}$, respectivamente.

$\mathrm{Na}$ Figura 11 verifica-se que a precipitação interna coletada nas "piscinas" para a altura de $0,25 \mathrm{~m}$ foi superior em relação à altura de $0,00 \mathrm{~m}$. Isso se deve à menor área foliar de contribuição para a retenção de água nas folhas do milho acima do plano situado a $0,25 \mathrm{~m}$ em relação ao solo. Esses resultados ocorreram para um IAF médio de toda a planta de 3,13. No entanto, as plantas na época (E2) foram divididas em duas partes, tendo na camada superior, no plano acima de $0,25 \mathrm{~m}$, um IAF médio de 1,09 , e no plano inferior um IAF médio de 3,13 , com contribuição de toda a planta.



Figura 11 - Valores percentuais de escoamento pelo colmo (Ec), interceptação foliar (INT) e precipitação interna (PI), em relação à precipitação total, nas alturas de coleta de água de 0,00 e $0,25 \mathrm{~m}$ em relação ao solo para as três parcelas analisadas.

Valores de precipitação interna inferiores aos encontrados neste estudo foram verificados por Conte \& Leopoldo (1986) e Haynes (1940), de 69,7 e 70,0\%, respectivamente. 
Essas diferenças entre os valores, provavelmente, estão relacionadas com a cultivar utilizada, a arquitetura da planta, a população de plantas, a metodologia adotada e a lâmina aplicada. Estudos realizados por Folegatti et al. (1998) relatam que a partição da precipitação total em precipitação interna, escoamento pelo colmo e interceptação foliar varia de acordo com a lâmina aplicada. Para a época (E2) foram encontrados valores médios de INT de 6,56 e 5,57\% e Ec de 7,87 e 6,12\% para as alturas de coletas de 0,00 e $0,25 \mathrm{~m}$, respectivamente.

Tabela 7. Valores médios de lâminas coletadas referentes às partições em precipitação interna (PI), escoamento pelo colmo (Ec) e interceptação foliar (INT) em relação à precipitação total (PT) aplicada via pivô central, e índice de área foliar (IAF), nas duas alturas na planta para a época (E2).

\begin{tabular}{ccccccc}
\hline Data & $\begin{array}{c}\text { Altura na planta } \\
(\mathrm{m})\end{array}$ & $\begin{array}{c}\text { PT } \\
(\mathrm{mm})\end{array}$ & $\begin{array}{c}\text { PI } \\
(\mathrm{mm})\end{array}$ & $\begin{array}{c}\mathrm{EC} \\
(\mathrm{mm})\end{array}$ & $\begin{array}{c}\text { INT } \\
(\mathrm{mm})\end{array}$ & $\begin{array}{c}\mathrm{IAF}^{*} \\
\left(\mathrm{~m}^{2} \mathrm{~m}^{-2}\right)\end{array}$ \\
\hline 2 20/out & 0,00 & 3,0 & 2,6 & 0,2 & 0,2 & 3,09 \\
& 0,25 & 3,0 & 2,7 & 0,2 & 0,2 & 1,09 \\
\hline $21 /$ out & 0,00 & 3,0 & 2,6 & 0,2 & 0,2 & 3,13 \\
& 0,25 & 3,0 & 2,7 & 0,2 & 0,2 & 1,09 \\
\hline 2 22/out & 0,00 & 3,0 & 2,6 & 0,2 & 0,2 & 3,16 \\
& 0,25 & 3,0 & 2,7 & 0,2 & 0,2 & 1,11 \\
\hline
\end{tabular}

* IAF acima do ponto de coleta

Analisando-se os efeitos das duas alturas de coleta na planta, metades inferior e superior, verificou-se diferença significativa para os valores médios observados de INT, Ec e PI entre as alturas 0,00 e 0,25 m. As variáveis INT e Ec foram significativamente afetadas pelas alturas de coleta, em que se verificou um acréscimo nos valores dessas variáveis, com a redução da altura na planta. No entanto, para a variável PI observou-se uma relação direta com a altura, sendo seus valores reduzidos com a diminuição da altura de coleta (Tabela 7). Essas diferenças são atribuídas, provavelmente, à própria arquitetura das plantas e às diferenças físicas entre as suas duas metades, pois, na camada superior o IAF médio foi de 1,09 , e para a camada inferior de 
2,03. Na metade inferior toda a planta contribui para a retenção de água, em que o IAF é o somatório das duas metades, resultando numa maior interceptação, e por outro lado, numa menor precipitação interna.

Para as outras amostragens, quando as plantas apresentavam maior desenvolvimento, com IAF variando de 4,29 a 4,78, tornou-se necessário acrescentar mais um plano horizontal de coleta, totalizando assim, três alturas de coletas de água na planta. Nesta época (E3), as coletas foram feitas nos três terços da planta, nos terços inferior $(0,00 \mathrm{~m})$, médio $(0,50 \mathrm{~m})$ e superior do milho $(1,40 \mathrm{~m})$.

$\mathrm{Na}$ altura de coleta de $1,40 \mathrm{~m}$ (terço superior) somente a área foliar acima desse plano influenciou na interceptação da lâmina aplicada via pivô. Da mesma forma, para o terço médio, toda a área foliar acima da altura de coleta de $0,50 \mathrm{~m}$ influenciou na retenção de água pela cultura do milho. E no terço inferior, para a altura de coleta de $0,00 \mathrm{~m}$, toda a planta contribuiu para retenção de água pelas folhas.

Os resultados médios das partições em precipitação interna (PI), escoamento pelo colmo do milho (Ec) e interceptação foliar (INT), em relação à precipitação total aplicada via pivô central, nas alturas de coletas de $0,00,0,50$ e 1,40m, durante o desenvolvimento da cultura são apresentados na Tabela 8

Quando as amostras de água foram coletadas no plano próximo ao solo 0,00m com IAF médio de 4,35, observou-se um escoamento médio pelo colmo (Ec) de 12,24\%, com uma interceptação foliar (INT) de 7,21\%, e uma precipitação interna (PI) média de $80,55 \%$ da lâmina total aplicada (Figura 12). Para altura de coleta de 0,00 m, os valores percentuais de (PI) observados, em função do IAF, variaram de 79,34 a $81,31 \%$. A variação percentual para os valores de (Ec) foi da ordem de 11,80 a $12,79 \%$, e para (INT) de 6,23 a 6,89\%. A magnitude dessas variações não foi acentuada, provavelmente, pela pequena variação do $\operatorname{IAF}(4,29$ a 4,78). Valores próximos aos observados neste estudo foram revelados por Haynes (1940), Conte \& Leopoldo (1986), Steiner et al. (1983) e Silva et al. (1994), em razão, principalmente, da metodologia utilizada, além de outros fatores, como a densidade de plantio, cultivar e lâmina. 
Tabela 8. Valores médios de lâminas coletadas referentes às partições em precipitação interna (PI), escoamento pelo colmo (Ec) e interceptação foliar (INT) em relação à precipitação total aplicada (PT) via pivô central e índice de área foliar (IAF), coletados nas três alturas na planta para a época (E3).

\begin{tabular}{ccccccc}
\hline Data & $\begin{array}{c}\text { Altura na planta } \\
(\mathrm{m})\end{array}$ & $\begin{array}{c}\text { PT } \\
(\mathrm{mm})\end{array}$ & $\begin{array}{c}\text { PI } \\
(\mathrm{mm})\end{array}$ & $\begin{array}{c}\text { EC } \\
(\mathrm{mm})\end{array}$ & $\begin{array}{c}\text { INT } \\
(\mathrm{mm})\end{array}$ & $\begin{array}{c}\text { IAF* }^{2} \\
\left(\mathrm{~m}^{2} \mathrm{~m}^{-2}\right)\end{array}$ \\
\hline \multirow{3}{*}{$08 /$ nov } & 0,00 & 3,0 & 2,4 & 0,4 & 0,3 & 4,42 \\
& 0,50 & 3,0 & 2,4 & 0,4 & 0,2 & 3,53 \\
& 1,40 & 3,0 & 2,5 & 0,4 & 0,1 & 0,89 \\
\hline \multirow{3}{*}{$09 /$ nov } & 0,00 & 3,0 & 2,5 & 0,4 & 0,2 & 4,38 \\
& 0,50 & 3,0 & 2,5 & 0,3 & 0,2 & 3,50 \\
& 1,40 & 3,0 & 2,6 & 0,4 & 0,1 & 0,88 \\
\hline \multirow{3}{*}{ 13/nov } & 0,00 & 3,0 & 2,5 & 0,4 & 0,2 & 4,39 \\
& 0,50 & 3,0 & 2,5 & 0,4 & 0,2 & 3,52 \\
& 1,40 & 3,0 & 2,5 & 0,4 & 0,1 & 0,87
\end{tabular}

* IAF acima do ponto de coleta

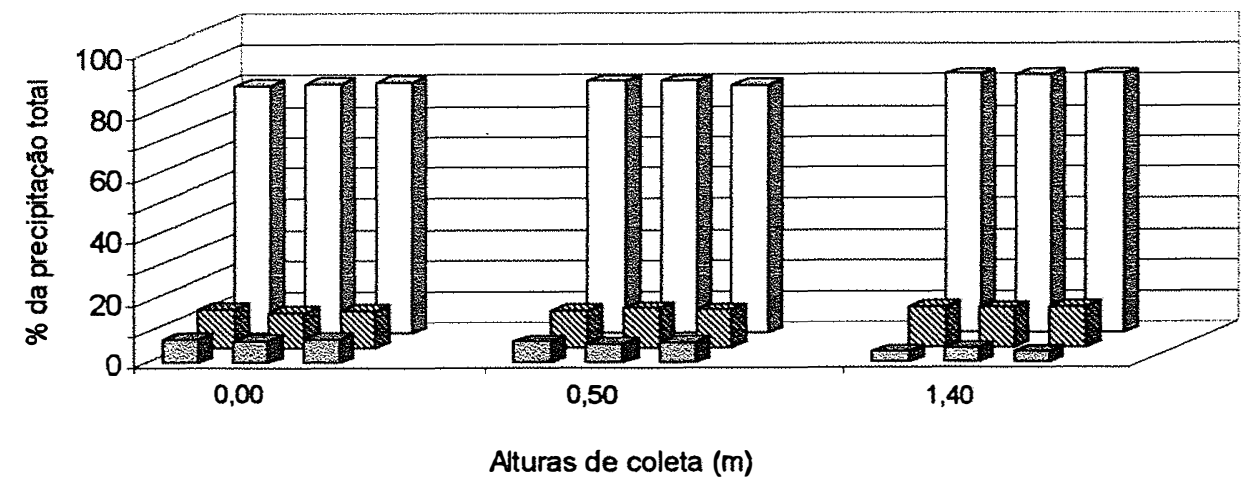

\section{맘 INT $\mathbb{E} E \mathrm{C} \quad \square \mathrm{PI}$}

Figura 12 - Valores percentuais de escoamento pelo colmo (Ec), interceptação foliar (INT) e precipitação interna (PI), em relação à precipitação total, nas alturas de coleta de água de 0,00,0,50 e 1,40m em relação ao solo para as três parcelas analisadas. 
Nos coletores instalados a $0,50 \mathrm{~m}$ de altura, os maiores valores de PI, Ec e INT foram $82,30,13,11$ e 6,89\%, respectivamente. No entanto, os menores valores de PI, Ec e INT foram da ordem de 80,33, 11,15 e 4,92\%, respectivamente, para o IAF médio de 3,64 .

Para a altura de coleta feita a $1,40 \mathrm{~m}$ em relação ao solo, quando a cultura apresentava um IAF médio de 0,75 para essa faixa, verificou-se que os maiores valores de PI, Ec e INT foram da ordem de 83,93, 13,44 e 4,26\%, respectivamente. No entanto, os menores valores de PI, Ec e INT foram $82,62,13,11$ e 2,62\%, respectivamente (Figura 12). As maiores variações obtidas para PI e Ec foram verificadas para a altura de coleta de $0,50 \mathrm{~m}$, podendo ser atribuídas, provavelmente, à maior área foliar de contribuição de plantas próximas à área de controle, natureza e desuniformidade das folhas.

As três alturas de coleta (terços superior, médio e inferior) na planta não promoveram diferenças significativas nas variáveis escoamento pelo colmo e precipitação interna. No entanto, observou-se diferença significativa para a variável interceptação da lâmina aplicada (Tabela 10). A variação significativa da interceptação da lamina aplicada promovida pelas alturas de coletas, provavelmente, se relaciona com a arquitetura, disposição das folhas (ângulo e natureza) e desigualdades de IAF sobre as áreas de coleta.

A análise da interceptação foliar da lâmina aplicada para a altura de $0,00 \mathrm{~m}$, nas três fases de desenvolvimento do milho ( 4,8 e 12 folhas), revelou diferenças significativas nas variáveis INT, IAF e concentrações de fertilizantes $\left(C_{N}, C_{K}\right.$ e $\left.C_{N K}\right)$ estudadas. De fato, é notório que as desigualdades entre IAF, número de folhas, ângulo e tamanho de folhas durante o ciclo da cultura foram responsáveis pelas diferenças significativas observadas nas variáveis PI, Ec e INT.

O aumento do IAF da cultura do milho promoveu redução da precipitação interna e um incremento nos valores de escoamento pelo colmo e interceptação foliar. A dependência funcional do estádio de desenvolvimento da cultura com a precipitação interna também foi verificada nos estudos de Leopoldo et al. (1981) e Basanta (1999). O aumento da altura de coleta de água em relação ao nível do solo proporcionou um 
aumento na estimativa dos valores de precipitação interna e escoamento pelo colmo e redução nos valores de interceptação foliar. Stone et al. (1994) observaram que o volume de água escoado pelo colmo aumentou à medida que diminui a altura de coletores em relação ao solo. Cabe ressaltar que os autores analisaram somente o volume escoado pelo colmo. Quinn \& Laften (1983) e Parkin \& Codling (1990) relatam que o volume escoado está diretamente relacionado com a massa do dossel e duração da aplicação de água, podendo reduzir com o aumento do tempo.

Considerando-se a lâmina máxima retida de $0,3 \mathrm{~mm}$ (Tabela 8) com índice de área foliar de 4,40, determinou-se que a lâmina máxima interceptada para essa fase de desenvolvimento foi $0,067 \mathrm{~mm}$, portanto, inferior à aplicada. Logo, a lâmina média aplicada de 3,0 $\mathrm{mm}$ foi suficientemente superior à máxima lâmina que a cultura é capaz de reter para o IAF médio 4,40, observado no início da fase de florescimento.

\subsection{Quantidade de fertilizante interceptado pelo dossel da cultura}

As concentrações de fertilizantes interceptados pela cultura do milho se relacionam diretamente com o volume de água coletado nas diferentes alturas analisadas da planta. Os resultados da interceptação de fertilizantes (nitrogênio e potássio) pelo dossel da cultura de milho, para os estádios fenológicos correspondentes $(4,8$ e 12 folhas), são apresentados nas Figuras 13, 14 e 15.

No estádio de desenvolvimento de 4 folhas (E1) as concentrações de fertilizantes encontradas na água de irrigação não apresentaram diferenças significativas. $\mathrm{Na}$ Figura 13 estão apresentados os valores médios de concentrações de nitrogênio $(\mathrm{N})$, potássio $\left(\mathrm{K}_{2} \mathrm{O}\right)$ e os dois juntos $\left(\mathrm{N}+\mathrm{K}_{2} \mathrm{O}\right)$ observados na calda de irrigação. As concentrações variaram de 0,194 a $0,197 \mathrm{~g} \mathrm{~L}^{-1}(\mathrm{~N}), 0,240$ a $0,247 \mathrm{~g} \mathrm{~L}^{-1}\left(\mathrm{~K}_{2} \mathrm{O}\right)$, e 0,849 a $0,897 \mathrm{~g} \mathrm{~L}^{-1}\left(\mathrm{~N}+\mathrm{K}_{2} \mathrm{O}\right)$. Essas pequenas diferenças observadas entre os valores das concentrações confirmam a proximidade entre uniformidade de distribuição de água e de produto químico, devido ao regime turbulento (Dourado Neto \& Fancelli, 1999). 


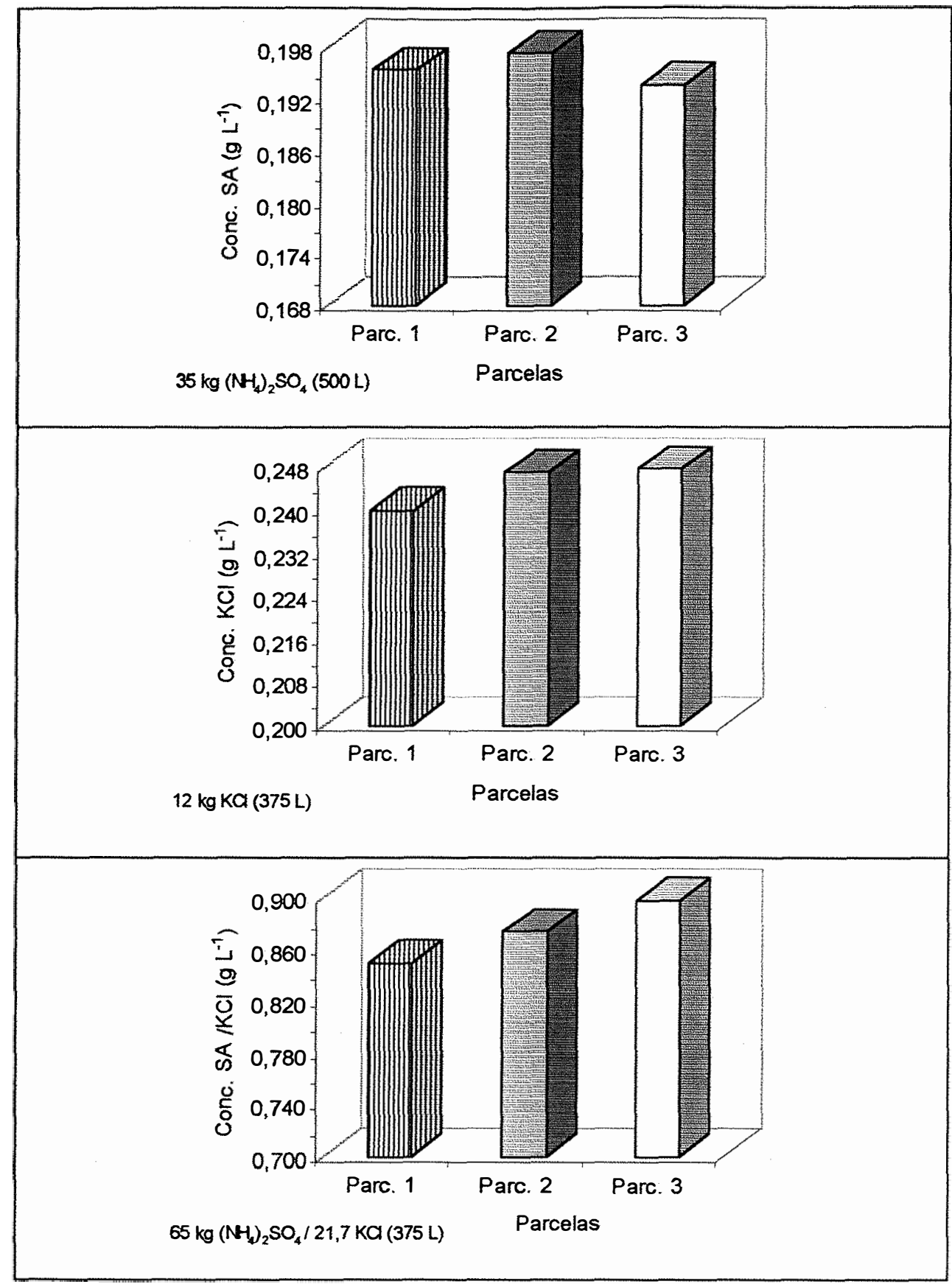

Figura 13 - Valores médios de concentrações de sulfato de amônio $\left.\left(\mathrm{NH}_{4}\right)_{2} \mathrm{SO}_{4}\right)$, cloreto de potássio $(\mathrm{KCL})$ e sulfato de amônio mais cloreto de potássio para as três parcelas na época $(\mathrm{E} 1) . \quad\left(\mathrm{NH}_{4}\right)_{2} \mathrm{SO}_{4}=\mathrm{SA}$. 


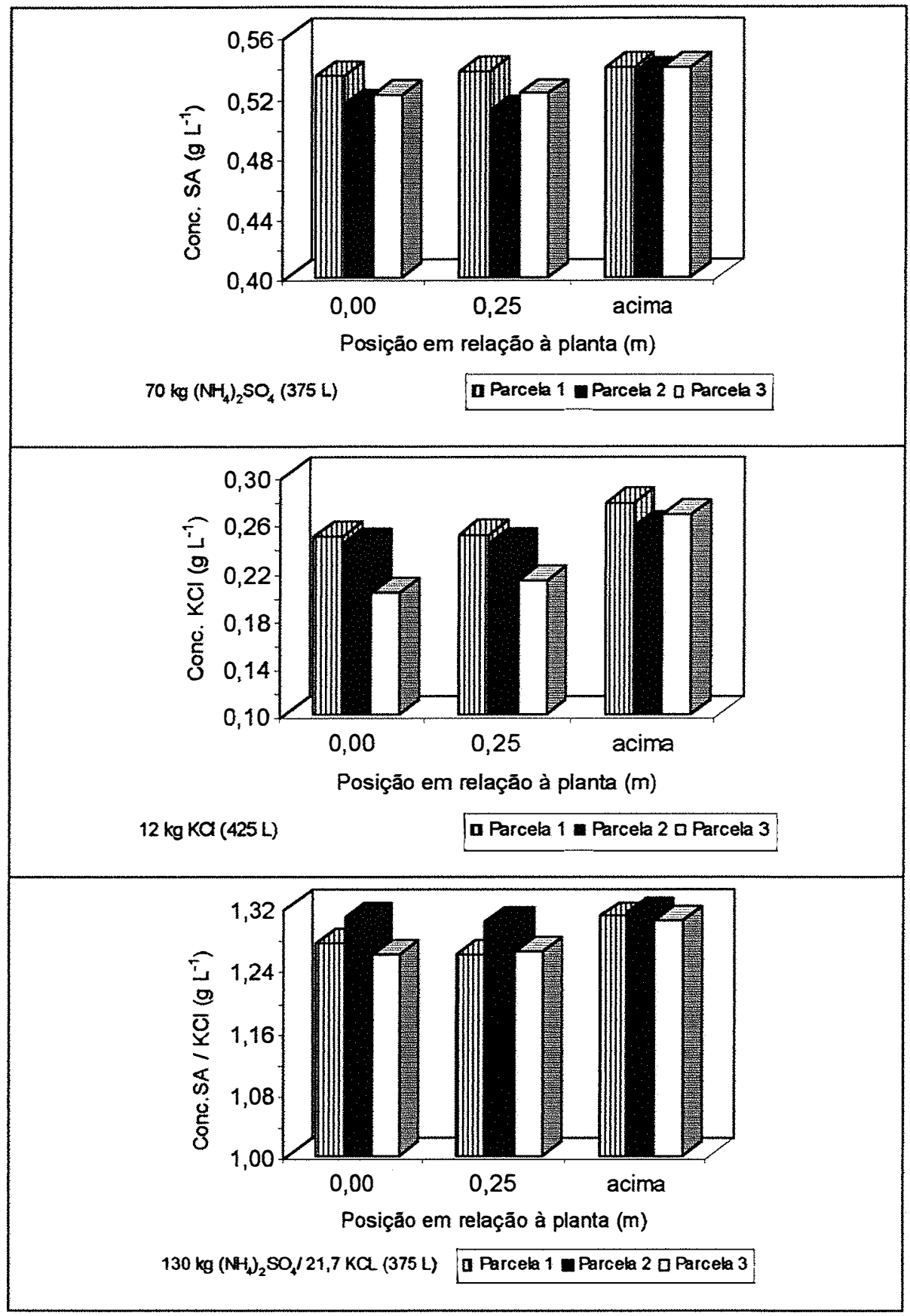

Figura 14 - Valores médios de concentrações de sulfato de amônio $\left(\mathrm{NH}_{4}\right)_{2} \mathrm{SO}_{4}$, cloreto de potássio (KCL) e sulfato de amônio mais cloreto de potássio para as duas posições $(0,00$ e $0,25 \mathrm{~m})$ e acima do dossel da cultura na época (E2). $\left(\mathrm{NH}_{4}\right)_{2} \mathrm{SO}_{4}=\mathrm{SA}$ 


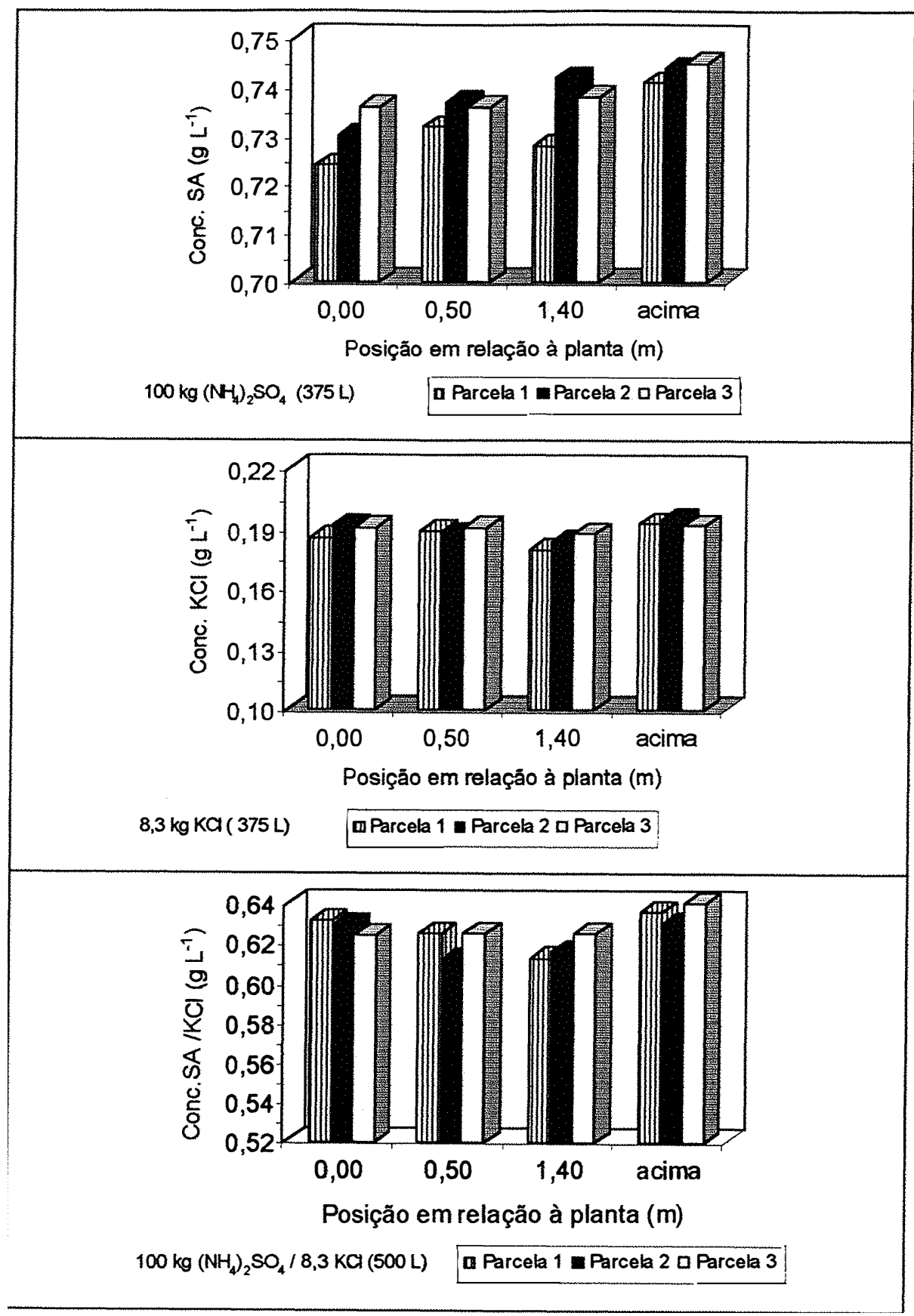

Figura 15 - Valores médios de concentrações de sulfato de amônio $\left.\left(\mathrm{NH}_{4}\right)_{2} \mathrm{SO}_{4}\right)$, cloreto de potássio (KCL) e sulfato de amônio mais cloreto de potássio para as três posições $(0,00,0,50$ e $1,40 \mathrm{~m})$ e acima do dossel da cultura na época (E3). $\left(\mathrm{NH}_{4}\right)_{2} \mathrm{SO}_{4}=\mathrm{SA}$ 
Para o estádio de desenvolvimento de 8 folhas (E2), as concentrações de fertilizantes foram observadas em duas metades na planta $(0,00$ e $0,25 \mathrm{~m})$. Os resultados revelaram que as alturas não promoveram diferenças significativas entre as concentrações de $\mathrm{N}, \mathrm{K}_{2} \mathrm{O}$ e $\mathrm{N}+\mathrm{K}_{2} \mathrm{O}$. Os valores das concentrações de fertilizantes são apresentados na Figura 14. Os valores de concentrações a $0,00 \mathrm{~m}$ variaram de 0,202 a $0,249 \mathrm{~g} \mathrm{~L}^{-1}\left(\mathrm{~K}_{2} \mathrm{O}\right), 0,515$ a $0,537 \mathrm{~g} \mathrm{~L}^{-1}(\mathrm{~N}), 1,260$ a $1,306 \mathrm{~g} \mathrm{~L}^{-1}\left(\mathrm{~N}+\mathrm{K}_{2} \mathrm{O}\right)$. Observou-se que para a altura de coleta de $0,25 \mathrm{~m}$ em relação ao solo, as concentrações variaram de 0,212 a $0,250 \mathrm{~g} \mathrm{~L}^{-1}\left(\mathrm{~K}_{2} \mathrm{O}\right), 0,510$ a $0,537 \mathrm{~g} \mathrm{~L}^{-1}(\mathrm{~N}), 1,259$ a $1,301 \mathrm{~g} \mathrm{~L}^{-1}\left(\mathrm{~N}+\mathrm{K}_{2} \mathrm{O}\right)$. Comparandose os valores das concentrações de fertilizantes nas duas alturas de coleta na planta de milho, verifica-se que as pequenas diferenças não promoveram efeito significativo (Tabela 9), devido à elevada uniformidade de aplicação de água que resultou em uma distribuição de fertilizantes proporcional a da água do pivô, concordando com Dourado Neto \& Fancelli (1999).

Tabela 9. Valores médios de índice de área foliar (IAF), lâmina de água interceptada (INT), escoamento pelo colmo (Ec), precipitação interna (PI), concentração de nitrogênio $\left(\mathrm{C}_{\mathrm{N}}\right)$, potássio $\left(\mathrm{C}_{\mathrm{K}}\right)$, nitrogênio mais potássio $\left(\mathrm{C}_{\mathrm{NK}}\right)$, interceptados pelo dossel da cultura para época (E2).

\begin{tabular}{l|c|ccc|ccc}
\hline \multicolumn{1}{c|}{ TRAT } & $\begin{array}{c}\text { IAF } \\
\left(\mathrm{m}^{2} \mathrm{~m}^{-2}\right)\end{array}$ & INT & $\begin{array}{c}\mathrm{Ec} \\
(\mathrm{mm})\end{array}$ & PI & $\mathrm{C}_{\mathrm{N}}$ & $\begin{array}{c}\mathrm{C}_{\mathrm{K}} \\
\left(\mathrm{g} \mathrm{L}^{-1}\right)\end{array}$ & $\mathrm{C}_{\mathrm{NK}}$ \\
\hline $1 / 2$ superior & $1,094 \mathbf{b}^{*}$ & $0,17 \mathbf{b}$ & $0,19 \mathbf{b}$ & $2,69 \mathbf{b}$ & $0,52 \mathbf{a}$ & $0,23 \mathbf{a}$ & $1,27 \mathbf{a}$ \\
$1 / 2$ inferior & $2,033 \mathbf{a}$ & $0,20 \mathbf{a}$ & $0,23 \mathbf{a}$ & $2,61 \mathbf{a}$ & $0,52 \mathbf{a}$ & $0,24 \mathbf{a}$ & $1,28 \mathbf{a}$ \\
\hline $\mathrm{CV}$ & 6,07 & 14,244 & 13,777 & 1,121 & 3,384 & 8,931 & 1,902 \\
Média & 1,564 & 0,19 & 0,21 & 2,65 & 0,523 & 0,236 & 1,277 \\
DMS-5\% & 0,0949 & 0,0264 & 0,0296 & 0,0307 & 0,0177 & 0,021 & 0,0243 \\
\hline
\end{tabular}

* Valores de uma mesma coluna com letras distintas são estatisticamente diferentes entre si, ao nível de significância de $5 \%$ pelo teste Tukey. 
No estádio de 12 folhas (E3) as alturas de coleta nas plantas não influenciaram de forma significativa nos valores de concentrações de fertilizantes (Tabela 10), devido à elevada uniformidade de aplicação de água que proporciona uma distribuição de fertilizantes proporcional a da água do pivô. Os valores observados se referem a um dos terços do dossel analisado.

A Figura 15 ilustra os valores de concentrações de fertilizantes observadas para os três terços (inferior, médio e superior) da planta. As concentrações médias para a altura de coleta de $0,00 \mathrm{~m}$ variaram de 0,724 a $0,730 \mathrm{~g} \mathrm{~L}^{-1}(\mathrm{~N}), 0,186 \mathrm{a}$ $0,191 \mathrm{~g} \mathrm{~L}^{-1}\left(\mathrm{~K}_{2} \mathrm{O}\right), 0,624$ a $0,631 \mathrm{~g} \mathrm{~L}^{-1}\left(\mathrm{~N}+\mathrm{K}_{2} \mathrm{O}\right)$. Para a altura de coleta de $0,50 \mathrm{~m}$, os valores médios de $\mathrm{N}$ variaram entre 0,732 a $0,737 \mathrm{~g} \mathrm{~L}^{-1}$, os valores médios de $\mathrm{K}_{2} \mathrm{O}$ entre 0,188 a $0,191 \mathrm{~g} \mathrm{~L}^{-1}$ e os de $\mathrm{N}+\mathrm{K}_{2} \mathrm{O}$ entre 0,612 a $0,625 \mathrm{~g} \mathrm{~L}^{-1}$. Para o terço superior, na altura de $1,40 \mathrm{~m}$, valores médios de $\mathrm{N}$ variaram entre 0,728 a $0,742 \mathrm{~g} \mathrm{~L}^{-1}$, os valores médios de $\mathrm{K}_{2} \mathrm{O}$ entre 0,180 a $0,188 \mathrm{~g} \mathrm{~L}^{-1}$ e os de $\mathrm{N}+\mathrm{K}_{2} \mathrm{O}$ entre 0,613 a $0,625 \mathrm{~g} \mathrm{~L}^{-1}$.

Tabela 10. Valores médios de índice de área foliar (IAF), lâmina de água interceptada (INT), escoamento pelo colmo $(\mathrm{Ec})$, precipitação interna $(\mathrm{PI})$, concentração de nitrogênio $\left(C_{N}\right)$, potássio $\left(C_{K}\right)$, nitrogênio mais potássio $\left(C_{N K}\right)$, interceptados pelo dossel da cultura para época (E3).

\begin{tabular}{|c|c|c|c|c|c|c|c|}
\hline TRAT & $\begin{array}{c}\text { IAF } \\
\left(\mathrm{m}^{2} \mathrm{~m}^{-2}\right)\end{array}$ & INT & $\begin{array}{c}\mathrm{Ec} \\
(\mathrm{mm})\end{array}$ & PI & $\mathrm{C}_{\mathrm{N}}$ & $\begin{array}{c}\mathrm{C}_{\mathrm{K}} \\
\left(\mathrm{g} \mathrm{L}^{-1}\right)\end{array}$ & $\mathrm{C}_{\mathrm{NK}}$ \\
\hline $1 / 3$ superior & $0,749 \mathbf{b}^{*}$ & 0,11 b & $0,38 \quad \mathbf{a}$ & $2,54 \mathbf{a}$ & $0,74 \mathbf{a}$ & $0,19 \mathbf{a}$ & $0,62 \mathbf{a}$ \\
\hline $1 / 3$ médio & $2,887 \mathbf{a}$ & $0,20 \mathbf{a}$ & $0,40 \quad \mathbf{a}$ & $2,49 \mathbf{a}$ & $0,74 \mathbf{a}$ & $0,19 \mathbf{a}$ & $0,62 \mathbf{a}$ \\
\hline $1 / 3$ inferior & $0,713 \quad \mathbf{b}$ & $0,22 \mathbf{a}$ & $0,41 \quad \mathbf{a}$ & $2,46 a$ & $0,74 \mathbf{a}$ & $0,19 \mathbf{a}$ & $0,62 \mathbf{a}$ \\
\hline $\mathrm{CV}$ & 14,688 & 36,66 & 12,17 & 2,80 & 0,896 & 2,207 & 1,330 \\
\hline Média & 1,450 & 0,17 & 0,39 & 2,49 & 0,735 & 0,187 & 0,622 \\
\hline DMS - $5 \%$ & 0,2505 & 0,0744 & 0,0564 & 0,0823 & 0,0077 & 0,0049 & 0,0097 \\
\hline
\end{tabular}

* Valores de uma mesma coluna com letras distintas são estatisticamente diferentes entre si, ao nível de de significância de $5 \%$ pelo teste Tukey. 
Comparando as concentrações de fertilizantes interceptadas pela cultura, durante os três estádios fenológicos da cultura de milho, na altura de $0,00 \mathrm{~m}$, constatouse que as concentrações de $\mathrm{N}, \mathrm{K}_{2} \mathrm{O}$ e $\mathrm{N}+\mathrm{K}_{2} \mathrm{O}$ foram significativamente diferentes em relação à época estudada (Tabela 11), reforçando a existência de uma correlação da massa do dossel e o volume coletado, conforme relatam Quinn \& Laften (1983) e Parkin \& Codling (1990).

As concentrações de fertilizantes $\left(C_{N}\right),\left(C_{K}\right)$ e $\left(C_{N K}\right)$ e suas respectivas quantidades $\left(t\right.$ ha $\left.^{-1}\right)$ para os três épocas analisadas (E1), (E2) e (E3) são apresentadas na Tabela 23 (anexo).

Tabela 11. Valores médios de índice de área foliar (IAF), lâmina de água interceptada (INT), concentração de nitrogênio $\left(C_{N}\right)$, potássio $\left(C_{K}\right)$, nitrogênio mais potássio $\left(\mathrm{C}_{\mathrm{NK}}\right)$, interceptados pelo dossel da cultura para os três estádios de desenvolvimento 4,8 e 12 folhas.

\begin{tabular}{cc|c|ccc}
\hline Trat & $\begin{array}{c}\text { IAF } \\
\left(\mathrm{m}^{2} \mathrm{~m}^{-2}\right)\end{array}$ & $\begin{array}{c}\mathrm{INT} \\
(\mathrm{mm})\end{array}$ & $\mathrm{C}_{\mathrm{N}}$ & $\begin{array}{c}\mathrm{C}_{\mathrm{K}} \\
\left(\mathrm{g} \mathrm{L}^{-1}\right)\end{array}$ & $\mathrm{C}_{\mathrm{NK}}$ \\
\hline 4 folhas & $0,286 \mathbf{a}$ & $0,06 \mathbf{a}$ & $0,196 \mathbf{a}$ & $0,245 \mathbf{a}$ & $0,873 \mathbf{a}$ \\
8 folhas & $3,128 \mathbf{b}$ & $0,37 \mathbf{b}$ & $0,518 \mathbf{b}$ & $0,234 \mathbf{b}$ & $1,276 \mathbf{b}$ \\
12 folhas & $4,347 \mathbf{c}$ & $0,52 \mathbf{c}$ & $0,542 \mathbf{c}$ & $0,188 \mathbf{c}$ & $0,622 \mathbf{c}$ \\
\hline CV & 10,037 & 19,983 & 1,351 & 5,199 & 1,879 \\
Média & 2,587 & 0,315 & 0,491 & 0,222 & 0,924 \\
DMS - 5\% & 0,3055 & 0,074 & 0,0077 & 0,0136 & 0,0204 \\
\hline
\end{tabular}

* Valores de uma mesma coluna com letras distintas são estatisticamente diferentes entre si, ao nível de de significância de $5 \%$ pelo teste Tukey.

4.4 Curvas ajustadas de condutividade elétrica em função da concentração de fertilizantes na água de irrigação

Foram ajustadas equações de concentração de fertilizante $\left(\mathrm{Ne} \mathrm{K}_{2} \mathrm{O}, \mathrm{g} \mathrm{L}^{-1}\right)$ e condutividade elétrica da água $\mathrm{CEa}\left(\mathrm{dS} \mathrm{m}^{-1}\right)$ aplicada pelo pivô (Figuras 16, 17 e 18). 
Foram confeccionadas nove curvas em laboratório (Tabela 24, anexo), reproduzindo-se as proporções idênticas às formuladas em campo. Para tal, diluíram-se amostras retiradas no tanque da bomba injetora, adicionando-se a mesma água de captação, e procurando tornar próximo à razão de diluição entre calda e vazão do pivô, obtendo-se uma curva de condutividade elétrica $\left(\mathrm{dS} \mathrm{m}^{-1}\right)$ em função da concentração de fertilizantes $\left(\mathrm{g} \mathrm{L}^{-1}\right)$, com pontos suficientes e dentro da faixa desejada.

Pela Figura 16 verifica-se a relação entre os valores de condutividade elétrica da calda de irrigação e as concentrações de nitrogênio e potássio, com as referidas equações ajustadas para as três caldas formuladas $(35 \mathrm{~kg}$ de sulfato de amônio diluídos em 500 litros, $12 \mathrm{~kg}$ de cloreto de potássio em 375 litros e $65 \mathrm{~kg}$ de sulfato de amônio mais $21,7 \mathrm{~kg}$ de cloreto de potássio em 375 litros) na época (E1). Observa-se que houve uma boa correlação entre os valores, resultando em elevados coeficientes de determinação.

Para as três caldas formuladas (70kg de sulfato de amônio diluídos em 375 litros, $12 \mathrm{~kg}$ de cloreto de potássio em 425 litros e $130 \mathrm{~kg}$ de sulfato de amônio mais $21,7 \mathrm{~kg}$ de cloreto de potássio em 375 litros) na época (E2), também foram observados altos valores de coeficiente de determinação nas equações lineares ajustadas (Figura 17).

Situações semelhantes foram verificadas na época (E3) para as três caldas formuladas (100kg de sulfato de amônio diluídos em 375 litros, $8,3 \mathrm{~kg}$ de cloreto de potássio em 375 litros e $100 \mathrm{~kg}$ de sulfato de amônio mais $8,3 \mathrm{~kg}$ de cloreto de potássio em 530 litros) em que os dados observados se correlacionaram linearmente, resultando também em valores elevados de coeficiente de determinação (Figura 18). Essas curvas foram úteis para relacionar os valores de condutividade elétrica da calda coletada com os valores de concentração de nitrogênio e/ou potássio interceptados pelo dossel da cultura de milho.

Os valores médios das concentrações de fertilizantes $\left(C_{N}, C_{K}\right.$ e $\left.C_{N K}\right)$ calculadas pelas equações ajustadas, em função da condutividade elétrica da água de irrigação, para as três épocas de coleta $(E 1),(E 2)$ e (E3), podem ser observados nas Tabelas 25,26 e 27 (anexo). 




Figura 16 - Relação entre condutividade elétrica CE $\left(\mathrm{dS} \mathrm{m}^{-1}\right)$ e concentrações $\left(\mathrm{g} \mathrm{L}^{-1}\right)$ de nitrogênio $(\mathrm{N})$ e potássio $\left(\mathrm{K}_{2} \mathrm{O}\right)$ e os dois juntos $\left(\mathrm{N}+\mathrm{K}_{2} \mathrm{O}\right)$ para as três caldas formuladas ( $\mathrm{kg}$ de fertilizante / volume de solução) no tanque de fertilizante, na época $(\mathrm{E} 1) . \mathrm{SA}=\left(\mathrm{NH}_{4}\right)_{2} \mathrm{SO}_{4}$ 


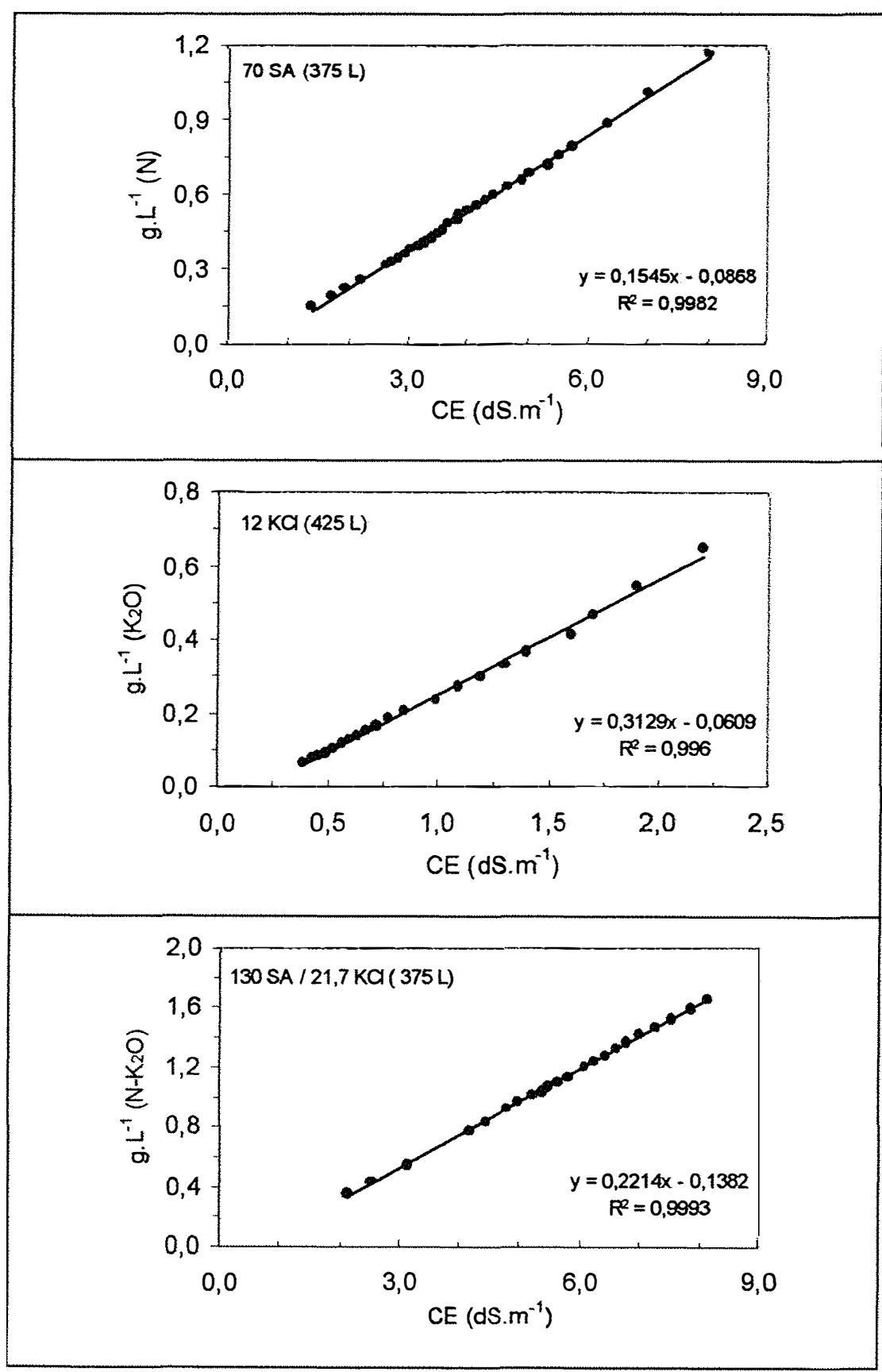

Figura 17 - Relação entre condutividade elétrica $\mathrm{CE}\left(\mathrm{dS} \mathrm{m} \mathrm{m}^{-1}\right)$ e concentrações $\left(\mathrm{g} \mathrm{L}^{-1}\right)$ de nitrogênio $(\mathrm{N})$ e potássio $\left(\mathrm{K}_{2} \mathrm{O}\right)$ e os dois juntos $\left(\mathrm{N}+\mathrm{K}_{2} \mathrm{O}\right)$ para as três caldas formuladas ( $\mathrm{kg}$ de fertilizante / volume de solução) no tanque de fertilizante, na época (E2). SA $=\left(\mathrm{NH}_{4}\right)_{2} \mathrm{SO}_{4}$ 


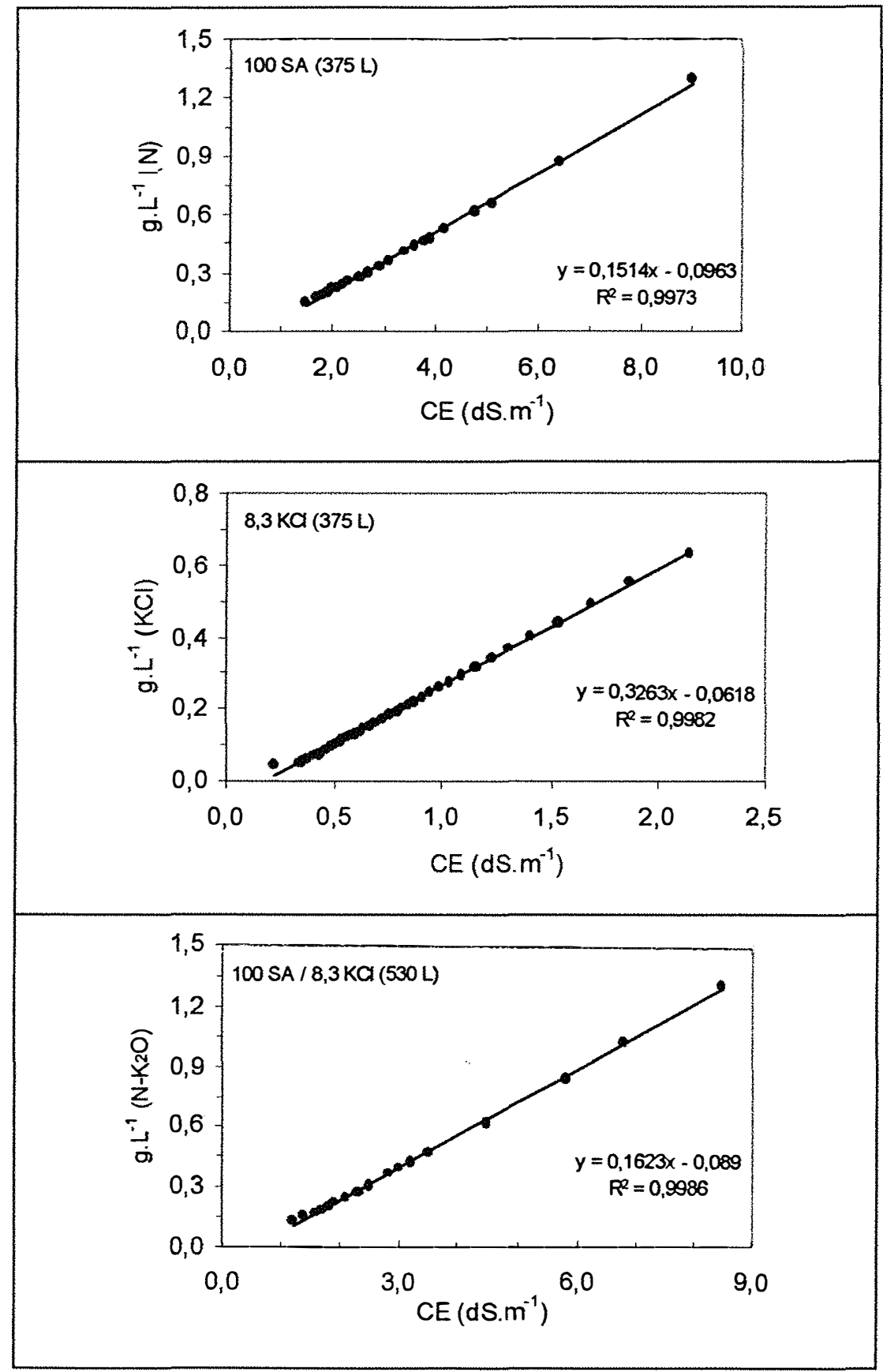

Figura 18 - Relação entre condutividade elétrica $\mathrm{CE}\left(\mathrm{dS} \mathrm{m} \mathrm{m}^{-1}\right)$ e concentrações $\left(\mathrm{g} \mathrm{L}^{-1}\right)$ de nitrogênio $(\mathrm{N})$ e potássio $\left(\mathrm{K}_{2} \mathrm{O}\right)$ e os dois juntos $\left(\mathrm{N}+\mathrm{K}_{2} \mathrm{O}\right)$ para as três caldas formuladas ( $\mathrm{kg}$ de fertilizante / volume de solução) no tanque de fertilizante, na época (E3). $\mathrm{SA}=\left(\mathrm{NH}_{4}\right)_{2} \mathrm{SO}_{4}$ 


\subsection{Desenvolvimento relativo da cultura}

Para a determinação do desenvolvimento relativo (Dr) consideraram-se os dados até o florescimento da cultura, fase em que as elongações do colmo e internódios se cessam (Fancelli \& Dourado Neto, 1996). Os resultados de desenvolvimento relativo da cultura são apresentados nas Tabelas 12, 13 e 14.

Tabela 12. Temperaturas máximas $\left(\mathrm{T} 1,{ }^{\circ} \mathrm{C}\right)$ e mínimas $\left(\mathrm{T} 2,{ }^{\circ} \mathrm{C}\right)$ do ar, número de grausdia, estádio fenológico, número de dias após a emergência (DAE) e desenvolvimento relativo da cultura (Dr) de milho desde a emergência (7/set) até 4 folhas (30/set).

\begin{tabular}{|c|c|c|c|c|c|c|c|}
\hline Data & $\mathrm{T}^{1}$ & $T 2^{1}$ & $\mathrm{Gdi}^{2}$ & $\mathrm{GDAi}^{3}$ & Estádio & $\mathrm{DAE}$ & Dr \\
\hline 07/09/98 & 26,5 & 15,4 & 11,0 & 11,0 & Emergência & 0 & 0,00 \\
\hline $08 /$ set & 24,6 & 17,7 & 11,2 & 22,1 & 0 folha & 1 & 0,03 \\
\hline 09/set & 25,6 & 16,1 & 10,9 & 33,0 & 0 folha & 2 & 0,04 \\
\hline $10 /$ set & 25,7 & 13,8 & 9,8 & 42,7 & 0 folha & 3 & 0,05 \\
\hline $11 /$ set & 32,1 & 13,6 & 12,9 & 55,6 & 0 folha & 4 & 0,07 \\
\hline $12 /$ set & 32,9 & 17,2 & 15,1 & 70,6 & 1 folha & 5 & 0,09 \\
\hline $13 /$ set & 33,1 & 17,2 & 15,2 & 85,8 & 1 folha & 6 & 0,10 \\
\hline $14 /$ set & 28,9 & 17,3 & 13,1 & 98,9 & 1 folha & 7 & 0,12 \\
\hline $15 /$ set & 28,6 & 15,1 & 11,9 & 110,7 & 1 folha & 8 & 0,14 \\
\hline $16 /$ set & 29,0 & 15,0 & 12,0 & 122,7 & 1 folha & 9 & 0,15 \\
\hline $17 /$ set & 35,6 & 14,3 & 15,0 & 137,7 & 2 folhas & 10 & 0,17 \\
\hline $18 /$ set & 31,9 & 17,9 & 14,9 & 152,6 & 2 folhas & 11 & 0,19 \\
\hline $19 /$ set & 25,9 & 17,0 & 11,5 & 164,0 & 2 folhas & 12 & 0,20 \\
\hline $20 /$ set & 23,3 & 15,5 & 9,4 & 173,4 & 2 folhas & 13 & 0,21 \\
\hline $21 /$ set & 24,8 & 14,8 & 9,8 & 183,2 & 2 folhas & 14 & 0,22 \\
\hline $22 /$ set & 23,8 & 12,1 & 8,0 & 191,2 & 3 folhas & 15 & 0,23 \\
\hline $23 /$ set & 26,0 & 13,1 & 9,6 & 200,7 & 3 folhas & 16 & 0,25 \\
\hline $24 /$ set & 30,8 & 11,9 & 11,4 & 212,1 & 3 folhas & 17 & 0,26 \\
\hline $25 /$ set & 30,1 & 14,8 & 12,5 & 224,5 & 3 folhas & 18 & 0,27 \\
\hline $26 /$ set & 30,2 & 15,0 & 12,6 & 237,1 & 3 folhas & 19 & 0,29 \\
\hline $27 /$ set & 31,2 & 18,0 & 14,6 & 251,7 & 4 folhas & 20 & 0,31 \\
\hline $28 /$ set & 22,4 & 18,2 & 10,3 & 262,0 & 4 folhas & 21 & 0,32 \\
\hline $29 /$ set & 22,5 & 18,8 & 10,7 & 272,7 & 4 folhas & 22 & 0,33 \\
\hline $30 /$ set & 23,7 & 17,0 & 10,4 & 283,0 & 4 folhas & 23 & 0,35 \\
\hline
\end{tabular}


Tabela 13. Temperaturas máximas $\left(\mathrm{T} 1,{ }^{\circ} \mathrm{C}\right)$ e mínimas $\left(\mathrm{T} 2,{ }^{\circ} \mathrm{C}\right)$ do ar, número de grausdia, estádio fenológico, número de dias após a emergência (DAE) e desenvolvimento relativo da cultura (Dr) de milho desde 4 folhas (01/out) até 13 folhas (05/nov).

\begin{tabular}{|c|c|c|c|c|c|c|c|}
\hline Data & $T 1^{1}$ & $\mathrm{~T}^{1}$ & Gdi $^{2}$ & $\mathrm{GDAi}^{3}$ & Estádio & $\mathrm{DAE}$ & $\mathrm{Dr}$ \\
\hline 01/out & 26,0 & 17,1 & 11,6 & 294,6 & 4 folhas & 24 & 0,36 \\
\hline 02/out & 27,1 & 14,8 & 11,0 & 305,5 & 4 folhas & 25 & 0,37 \\
\hline 03/out & 29,9 & 14,7 & 12,3 & 317,8 & 4 folhas & 26 & 0,39 \\
\hline 04/out & 32,2 & 16,1 & 14,2 & 332,0 & 5 folhas & 27 & 0,41 \\
\hline 05/out & 23,0 & 18,8 & 10,9 & 342,9 & 5 folhas & 28 & 0,42 \\
\hline 06/out & 28,6 & 15,3 & 12,0 & 354,8 & 5 folhas & 29 & 0,43 \\
\hline 07/out & 22,9 & 17,1 & 10,0 & 364,8 & 5 folhas & 30 & 0,45 \\
\hline 08/out & 27,3 & 17,2 & 12,3 & 377,1 & 5 folhas & 31 & 0,46 \\
\hline 09/out & 24,4 & 17,8 & 11,1 & 388,2 & 5 folhas & 32 & 0,47 \\
\hline 10/out & 26,9 & 13,4 & 10,2 & 398,3 & 6 folhas & 33 & 0,49 \\
\hline 11/out & 20,3 & 13,5 & 6,9 & 405,2 & 6 folhas & 34 & 0,50 \\
\hline 12/out & 26,0 & 16,2 & 11,1 & 416,3 & 6 folhas & 35 & 0,51 \\
\hline 13/out & 28,9 & 17,5 & 13,2 & 429,5 & 6 folhas & 36 & 0,53 \\
\hline 14/out & 30,8 & 15,9 & 13,4 & 442,9 & 6 folhas & 37 & 0,54 \\
\hline $15 /$ out & 33,1 & 14,8 & 14,0 & 456,8 & 7 folhas & 38 & 0,56 \\
\hline $16 /$ out & 24,2 & 17,6 & 10,9 & 467,7 & 7 folhas & 39 & 0,57 \\
\hline 17/out & 26,0 & 17,3 & 11,7 & 479,4 & 7 folhas & 40 & 0,59 \\
\hline $18 /$ out & 22,5 & 15,8 & 9,2 & 488,5 & 7 folhas & 41 & 0,60 \\
\hline 19/out & 27,7 & 13,7 & 10,7 & 499,2 & 8 folhas & 42 & 0,61 \\
\hline 20/out & 29,9 & 15,7 & 12,8 & 512,0 & 8 folhas & 43 & 0,63 \\
\hline 21/out & 31,5 & 15,6 & 13,6 & 525,6 & 8 folhas & 44 & 0,64 \\
\hline 22/out & 31,2 & 15,0 & 13,1 & 538,7 & 8 folhas & 45 & 0,66 \\
\hline 23/out & 32,4 & 17,5 & 15,0 & 553,6 & 9 folhas & 46 & 0,68 \\
\hline 24/out & 26,2 & 18,2 & 12,2 & 565,8 & 9 folhas & 47 & 0,69 \\
\hline $25 /$ out & 28,9 & 17,4 & 13,2 & 579,0 & 9 folhas & 48 & 0,71 \\
\hline 26/out & 24,4 & 17,7 & 11,1 & 590,0 & 10 folhas & 49 & 0,72 \\
\hline 27/out & 23,6 & 17,0 & 10,3 & 600,3 & 10 folhas & 50 & 0,73 \\
\hline $28 /$ out & 28,9 & 18,4 & 13,7 & 614,0 & 10 folhas & 51 & 0,75 \\
\hline 29/out & 31,4 & 16,6 & 14,0 & 628,0 & 11 folhas & 52 & 0,77 \\
\hline 30/out & 20,5 & 17,4 & 9,0 & 636,9 & 11 folhas & 53 & 0,78 \\
\hline 31/out & 22,1 & 15,2 & 8,7 & 645,6 & 11 folhas & 54 & 0,79 \\
\hline 01/nov & 26,8 & 14,2 & 10,5 & 656,1 & 12 folhas & 55 & 0,80 \\
\hline $02 /$ nov & 26,8 & 14,1 & 10,5 & 666,5 & 12 folhas & 56 & 0,82 \\
\hline $03 /$ nov & 25,2 & 14,8 & 10,0 & 676,5 & 12 folhas & 57 & 0,83 \\
\hline 04/nov & 29,5 & 12,2 & 10,9 & 687,4 & 13 folhas & 58 & 0,84 \\
\hline 05/nov & 32,3 & 16,0 & 14,2 & 701,5 & 13 folhas & 59 & 0,86 \\
\hline
\end{tabular}

Fonte: Depto. Ciências Exatas - ESALQ/USP (Posto meteorológico)

${ }^{2}$ Gdi: número de graus-dia $\left({ }^{\circ} \mathrm{C}\right.$ dia $)$ no i-ésimo dia após a emergência

${ }^{3} \mathrm{GDAi}$ : número de graus-dia $\left({ }^{\circ} \mathrm{C}\right.$ dia $)$ até o i-ésimo dia após a emergência 
Tabela 14. Temperaturas máximas $\left(\mathrm{T} 1,{ }^{\circ} \mathrm{C}\right)$ e mínimas $\left(\mathrm{T} 2,{ }^{\circ} \mathrm{C}\right)$ do ar, número de grausdia, estádio fenológico, número de dias após a emergência (DAE) e desenvolvimento relativo da cultura (Dr) de milho desde 13 folhas (06/nov) até o início do florescimento (14/nov).

\begin{tabular}{cccccccc}
\hline Data & $\mathrm{T}^{1}$ & $\mathrm{~T}^{1}$ & $\mathrm{Gdi}^{2}$ & $\mathrm{GDAi}^{3}$ & Estádio & $\mathrm{DAE}$ & $\mathrm{Dr}$ \\
\hline 06/nov & 32,9 & 17,0 & 15,0 & 716,5 & 13 folhas & 60 & 0,88 \\
07/nov & 32,9 & 16,4 & 14,7 & 731,1 & 14 folhas & 61 & 0,89 \\
08/nov & 31,9 & 18,5 & 15,2 & 746,3 & 14 folhas & 62 & 0,91 \\
09/nov & 31,9 & 17,6 & 14,8 & 761,1 & 14 folhas & 63 & 0,93 \\
10/nov & 23,3 & 17,6 & 10,6 & 771,7 & Pendão & 64 & 0,94 \\
11/nov & 24,2 & 18,0 & 11,1 & 782,8 & Pendão & 65 & 0,96 \\
12/nov & 29,4 & 14,7 & 12,1 & 794,8 & Pendão & 66 & 0,97 \\
13/nov & 25,9 & 15,4 & 10,5 & 805,3 & Pendão & 67 & 0,99 \\
14/nov & 28,4 & 15,9 & 12,2 & 817,4 & Florescimento & 68 & 1,00 \\
\hline
\end{tabular}

Fonte: Depto. Ciências Exatas - ESALQ/USP (Posto meteorológico)

${ }^{2} \mathrm{Gdi}$ : número de graus-dia $\left({ }^{\circ} \mathrm{C}\right.$ dia) no i-ésimo dia após a emergência

${ }^{3} \mathrm{GDAi}$ : número de graus-dia $\left({ }^{\circ} \mathrm{C}\right.$ dia) até o i-ésimo dia após a emergência

\subsection{Modelos para estimativa de fertilizante interceptado pela cultura de milho}

Foram propostos modelos para correlacionar os valores de lâmina ( $\mathrm{mm}$ ), quantidade de nitrogênio $\left(\mathrm{QN}, \mathrm{t} \mathrm{ha}^{-1}\right)$ e potássio $\left(\mathrm{QK}, \mathrm{t} \mathrm{ha}^{-1}\right)$ interceptados pelas folhas de milho, em função do desenvolvimento relativo (Dr) e índice de área foliar (IAF). Os modelos propostos serviram para diferenciar as quantidades de fertilizantes e lâminas retidas pela folhagem do milho, e não para distinguir as fases de crescimento da cultura. As diferenças são devidas ao aumento da área foliar que promove uma maior retenção da lâmina de água e quantidade de produtos aplicados via água de irrigação.

Em geral, os modelos encontrados na literatura relacionam a interceptação de luz com o índice de área foliar, que são representados por funções exponenciais (Trpani et al., 1992; Flenet et al., 1996; Maddoni \& Otegui, 1996; Castroa \& Fetchera, 1998). Em outros trabalhos o índice de área foliar em função da lâmina interceptada (Basanta, 1999; Silva et al., 1994, Conte \& Leopoldo, 1986). Os modelos obtidos neste estudo são representados também por equações exponenciais, que 


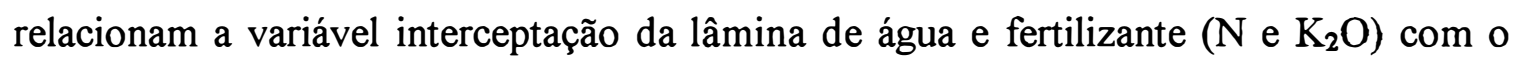
índice de área foliar e desenvolvimento relativo.

$\mathrm{Na}$ Tabela 15 e Figura 19 verifica-se o modelo encontrado que relaciona o desenvolvimento relativo da cultura do milho com a interceptação da lâmina aplicada (INT). A equação exponencial encontrada apresentou um alto coeficiente de correlação, e significativo ao nível de $1 \%$ de probabilidade. $O$ modelo permite estimar em termos de planejamento, a interceptação da lâmina aplicada na cultura do milho, conhecendo-se os valores de desenvolvimento relativo da cultura para o estádio fenológico até 12 folhas.

Os modelos para estimar as quantidades de potássio (Tabela 16 e Figura 20) e de nitrogênio (Tabela 17 e Figura 21) interceptados pela cultura do milho em função do desenvolvimento relativo da cultura foram significativos ao nível de $1 \%$ de probabilidade, apresentando elevados coeficientes de correlação. $O$ produto entre concentração de fertilizante e lâmina interceptada fornece a quantidade de fertilizante interceptado pela planta (Equação 13). A partir dos modelos apresentados nas Tabelas 15, 16 e 17, a interceptação da lâmina aplicada e as quantidades de fertilizantes interceptados pelo dossel da cultura podem ser estimadas em função do desenvolvimento relativo da cultura.

A análise dos resultados para a variável lâmina interceptada mostrou que o desenvolvimento relativo (representado pela variável IAF nas épocas de avaliações) foi significativo $(\alpha=0,05)$ pelo teste Tukey (Tabela 11). Dessa forma, justifica-se o resultado da análise de variância a relação existente entre desenvolvimento relativo da cultura e interceptação da lâmina pelo dossel. Verifica-se que a retenção de água pela folhagem da planta de milho foi diretamente proporcional ao desenvolvimento relativo da cultura. Isso não seria esperado se as folhas da cultura representassem uma área horizontal homogênea que interceptaria uma lâmina de água constante. Contudo, devido à arquitetura da planta de milho, à medida que se desenvolve, produz o efeito "funil", armazenando água na inserção da folha no colmo na altura da bainha, tal como foi observado por Stone et al. (1994) e Basanta (1999). 
Tabela 15. Modelo referente à estimativa da lâmina interceptada (INT, mm) em função do desenvolvimento relativo da cultura (Dr), com os respectivos valores de coeficiente de correlação (r), número de observações (n), desvio-padrão do erro $(\mathrm{s}, \mathrm{mm})$ e valor $\mathrm{F}$.

$$
\mathrm{INT}=\mathrm{a}+\mathrm{be}^{-\mathrm{DT}}
$$

\section{Parâmetros do modelo}

A $\quad 1,00246$

B $-1,27492$

\section{Parâmetros estatísticos}

$$
r
$$

n

$0,8908^{* *}$

s $\quad 0,09716$

$\mathrm{F}$
27

100,0

** Significativo ao nível de $1 \%$ de probabilidade $\left(\mathrm{r}_{240,01}=0,496\right)$

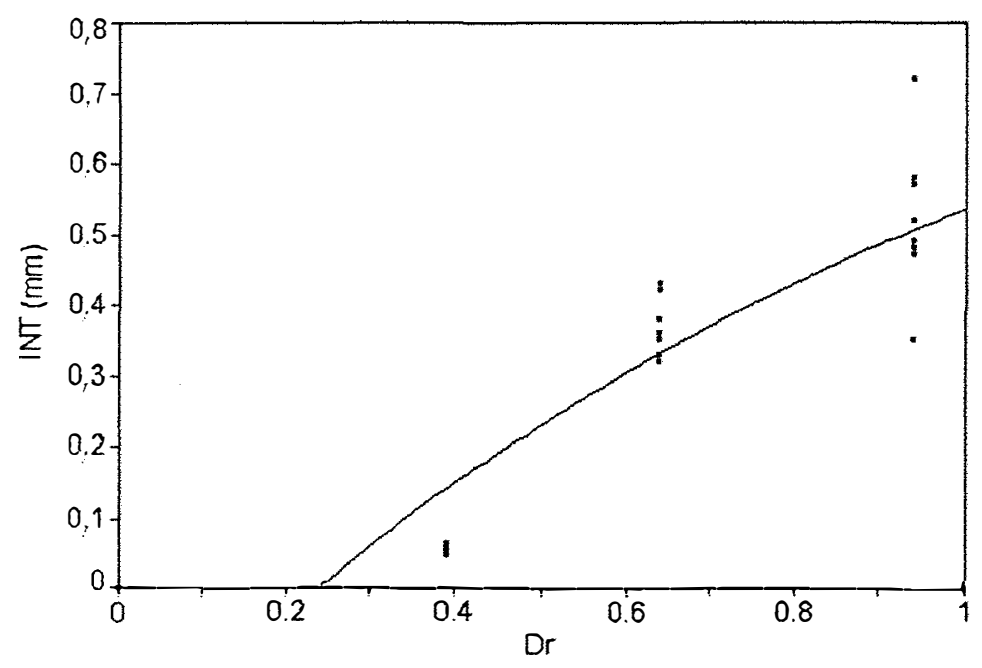

Figura 19 - Lâmina interceptada (INT, mm) em função do desenvolvimento relativo da cultura (Dr). 
Tabela 16. Modelo referente à estimativa da quantidade de potássio $\left(\mathrm{QK}, \mathrm{t} \mathrm{ha}^{-1}\right)$ interceptado em função do desenvolvimento relativo da cultura (Dr), com os respectivos valores de coeficiente correlação (r), número de observações (n), desvio-padrão do erro (s, $\left.\mathrm{t} \mathrm{ha}^{-1}\right) \mathrm{e}$ valor $\mathrm{F}$.

$$
\mathrm{QK}=\mathrm{a}+\mathrm{be}^{-\mathrm{Dr}}
$$

Parâmetros do modelo

Parâmetros estatísticos

$\begin{array}{cccc}\mathrm{a} & 0,001938 & \mathrm{r} & 0,8600^{* *} \\ \mathrm{~b} & -0,001938 & \mathrm{n} & 27 \\ & & \mathrm{~s} & 0,001938 \\ & & \mathrm{~F} & 73,90\end{array}$

* Significativo ao nível de $1 \%$ de probabilidade $\left(\mathrm{r}_{24-0,01}=0,496\right)$

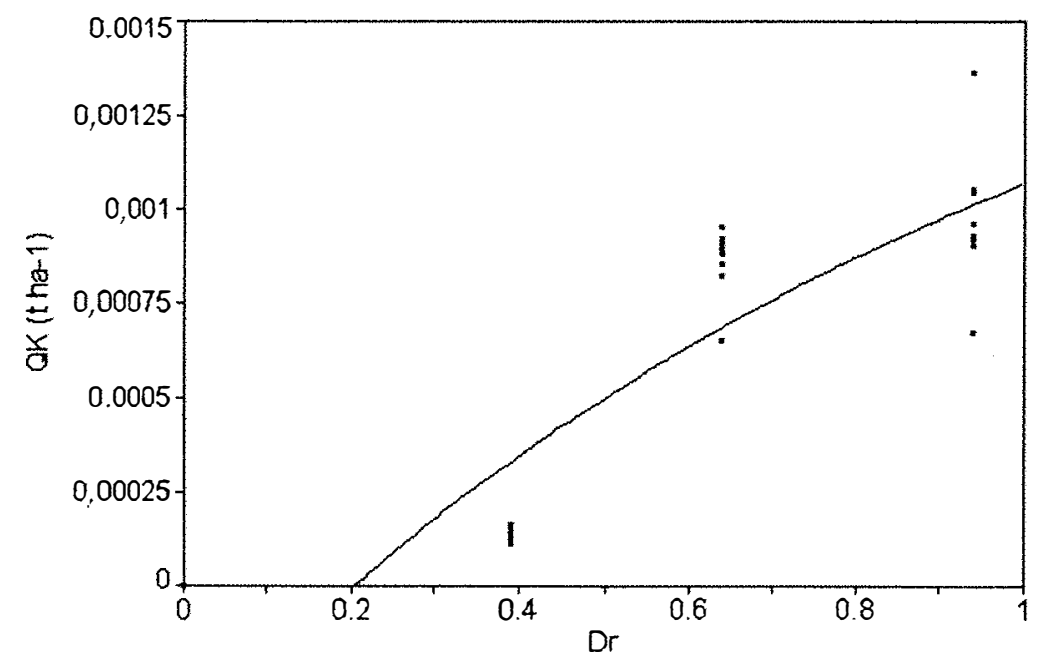

Figura 20 - Quantidade de potássio interceptado $\left(\mathrm{QK}, \mathrm{t} \mathrm{ha}^{-1}\right)$ em função do desenvolvimento relativo da cultura (Dr). 
Tabela 17. Modelo referente à estimativa da quantidade de nitrogênio ( $\left.\mathrm{QN}, \mathrm{t} \mathrm{ha}^{-1}\right)$ interceptado em função do desenvolvimento relativo da cultura (Dr), com os respectivos valores de coeficiente de correlação (r), número de observações (n), desvio-padrão do erro ( $\left.s, t_{\text {h ha }}{ }^{-1}\right)$ e valor $F$.

\begin{tabular}{cccc}
\hline & \multicolumn{3}{c}{$\mathrm{QN}=\mathrm{a}+\mathrm{be}^{-\mathrm{DT}}$} \\
\hline & Parâmetros do modelo & & Parâmetros estatísticos \\
$\mathrm{a}$ & 0,00723 & $\mathrm{r}$ & $0,8876^{* *}$ \\
$\mathrm{~b}$ & $-0,00972$ & $\mathrm{n}$ & 27 \\
& & $\mathrm{~s}$ & 0,000754 \\
& $\mathrm{~F}$ & 96,6 \\
\hline
\end{tabular}

** Significativo ao nível de $1 \%$ de probabilidade $\left(\mathrm{r}_{24-0,01}=0,496\right)$

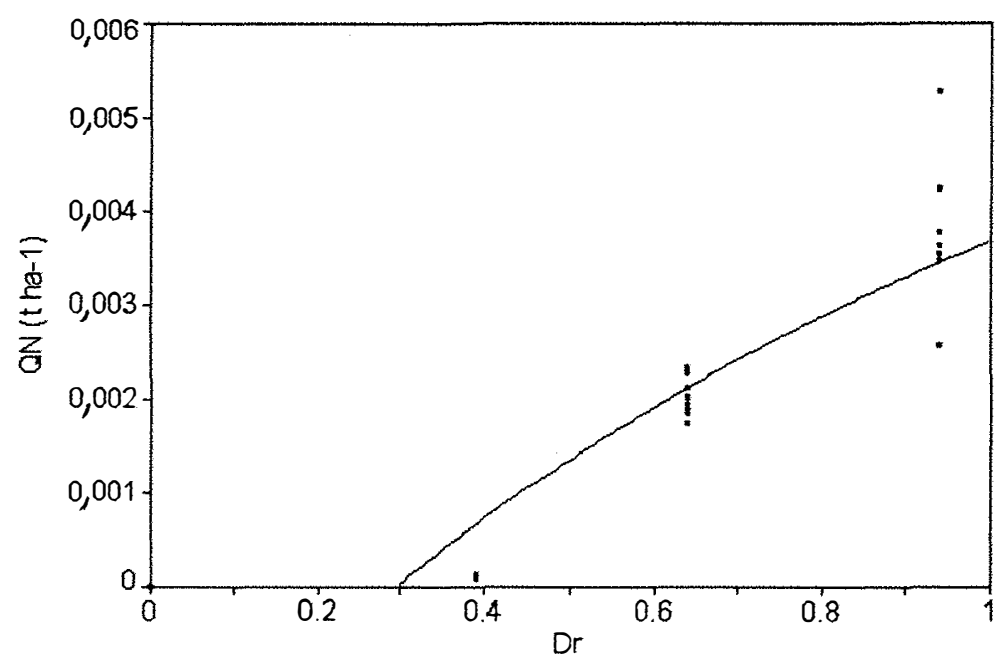

Figura 21 - Quantidade de nitrogênio interceptado ( $\mathrm{QN}, \mathrm{t}$ ha ${ }^{-1}$ ) em função do desenvolvimento relativo da cultura (Dr). 
Assim, o volume de água retido na parte aérea das plantas foi estimado em função do desenvolvimento relativo da cultura, obtendo-se as quantidades estimadas de fertilizantes $\left(\mathrm{N}\right.$ e $\mathrm{K}_{2} \mathrm{O}$ ) interceptados nas folhagens do milho em função da concentração da calda retida nas folhas.

Utilizam-se o índice de área foliar com a finalidade de manejo, e o desenvolvimento relativo da cultura com a finalidade de planejamento das ações de manejo. Para efeito de planejamento, com os modelos propostos, pode-se estimar a quantidade máxima utilizável na aplicação foliar de um produto químico, em função de um determinado desenvolvimento relativo da cultura de milho (Tabelas 16 e 17).

$\mathrm{Na}$ Tabela 18 e Figura 22 observa-se o modelo encontrado que explica a relação funcional do índice de área foliar com a interceptação da lâmina aplicada (INT). A equação exponencial apresentou um coeficiente de correlação significativo ao nível de $1 \%$ de probabilidade. Quando for necessária a aplicação de um produto cujo o alvo for as folhas das plantas, o modelo permite estimar em termos de manejo, a interceptação da lâmina aplicada (ou volume) pela cultura do milho, com base no índice de área foliar da cultura para o estádio fenológico até 12 folhas.

Os modelos para estimar as quantidades de potássio (Tabela 19 e Figura 23) e de nitrogênio (Tabela 20 e Figura 24) interceptados pela cultura do milho em função do índice de área foliar da cultura foram significativos ao nível de $1 \%$ de probabilidade, apresentando elevados coeficientes de correlação. A partir do modelo referente à interceptação da lâmina aplicada, as quantidades de fertilizantes interceptados pelo dossel da cultura podem ser obtidas em função do índice de área foliar.

A análise dos resultados mostrou efeito significativo $(\alpha=0,05)$ pelo teste Tukey para a variável lâmina interceptada entre as épocas de avaliação (E1), (E2) e (E3). Para fins de manejo da cultura, quando for necessária a aplicação de um produto químico cujo alvo sejam as folhas das plantas, a quantidade máxima $\left(\mathrm{t}\right.$ ha $\left.{ }^{-1}\right)$ utilizável na aplicação foliar de um produto químico, também pode ser estimada em função do índice da área foliar (Tabelas 19 e 20). O modelo é, portanto, uma ferramenta para decidir 
sobre o equipamento a realizar uma aplicação do produto mais eficiente, e também se é factível a quimigação.

Tabela 18. Modelo referente à estimativa da lâmina interceptada (INT, mm) em função do índice de área foliar (IAF, $\mathrm{m}^{2} \mathrm{~m}^{-2}$ ), com os respectivos valores de coeficiente de correlação (r), número de observações (n), desvio-padrão do erro $(\mathrm{s}, \mathrm{mm}) \mathrm{e}$ valor $\mathrm{F}$.

$$
\mathrm{INT}=\mathrm{a}+\mathrm{be}^{-\mathrm{IAF}}
$$

Parâmetros do modelo

Parâmetros estatísticos

$\begin{array}{cccc}\mathrm{a} & 0,414772 & \mathrm{r} & 0,8430^{* *} \\ \mathrm{~b} & -0,60776 & \mathrm{n} & 27 \\ & & \mathrm{~s} & 0,11954 \\ & & \mathrm{~F} & 132,59\end{array}$

** Significativo ao nível de $1 \%$ de probabilidade $(\mathrm{r}$ 24-0,01 =0,496)

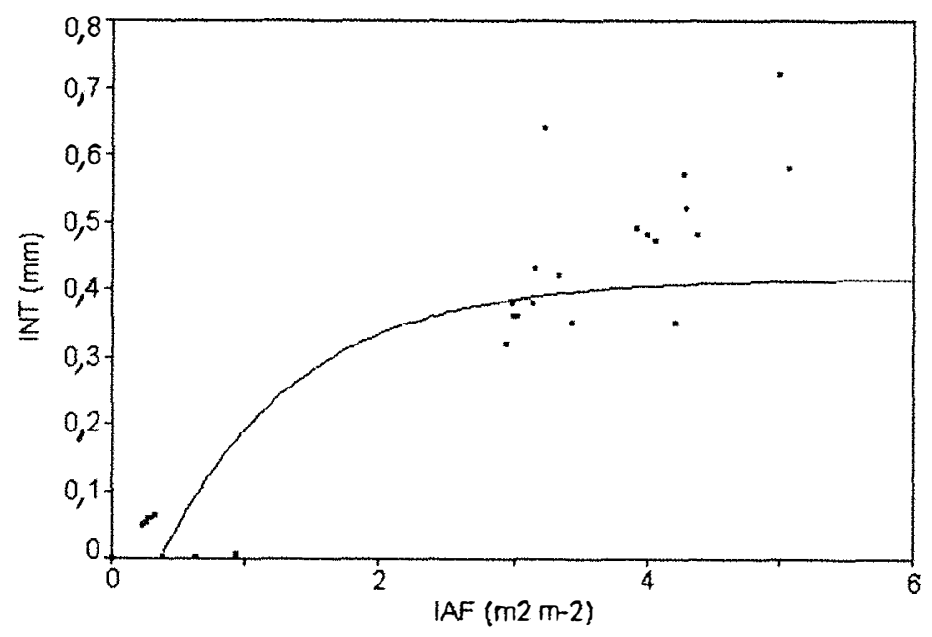

Figura 22 - Lâmina de água interceptada (INT, mm) em função do índice de área foliar (IAF, $\mathrm{m}^{2} \mathrm{~m}^{-2}$ ). 
Tabela 19. Modelo referente à estimativa da quantidade de potássio $\left(\mathrm{QK}, \mathrm{t}\right.$ ha $\left.{ }^{-1}\right)$ interceptado em função do índice de área foliar (IAF, $\mathrm{m}^{2} \mathrm{~m}^{-2}$ ), com os respectivos valores de coeficiente de correlação (r), número de observações (n), desvio-padrão do erro (s, tha $\left.{ }^{-1}\right)$ e valor $\mathrm{F}$.

\begin{tabular}{cccc}
\hline & \multicolumn{3}{c}{$\mathrm{QK}=\mathrm{a}+\mathrm{be}^{-\mathrm{IAF}}$} \\
\hline & Parâmetros do modelo & & Parâmetros estatísticos \\
$\mathrm{a}$ & 0,0009455 & $\mathrm{r}$ & $0,9563^{* *}$ \\
$\mathrm{~b}$ & $-0,001054$ & $\mathrm{n}$ & 27 \\
& & $\mathrm{~s}$ & 0,000121 \\
& $\mathrm{~F}$ & 278,08 \\
\hline
\end{tabular}

** Significativo ao nível de $1 \%$ de probabilidade $\left(\mathrm{r}_{240,01}=0,496\right)$



Figura 23 - Quantidade de potássio interceptado $\left(\mathrm{QK}, \mathrm{t} \mathrm{ha}^{-1}\right)$ em função do índice de área foliar (IAF, $\mathrm{m}^{2} \mathrm{~m}^{-2}$ ). 
Tabela 20. Modelo referente à estimativa da quantidade de nitrogênio ( $\left.\mathrm{QN}, \mathrm{t} \mathrm{ha}^{-1}\right)$ interceptado em função do índice de área foliar (IAF, $\mathrm{m}^{2} \mathrm{~m}^{-2}$ ), com os respectivos valores de coeficiente de correlação ( $\mathrm{r}$ ), número de observações (n), desvio-padrão do erro (s, $\left.\mathrm{t} \mathrm{ha}^{-1}\right)$ e valor $\mathrm{F}$.

$$
\mathrm{QN}=\mathrm{a}+\mathrm{be}^{-\mathrm{IAF}}
$$

Parâmetros do modelo

Parâmetros estatísticos

a

$$
0,0030140
$$

b

$-0,0037584$

r

$0,8606 * *$

n

27

$\mathrm{S}$

0,003014

F

74,27

** Significativo ao nível de $1 \%$ de probabilidade $\left(\mathrm{r}_{24-0,01}=0,496\right)$



Figura 24 - Quantidade de potássio interceptado $\left(\mathrm{QN}, \mathrm{t} \mathrm{ha}^{-1}\right)$ em função do índice de área foliar (IAF, $\left.\mathrm{m}^{2} \mathrm{~m}^{-2}\right)$. 
Salienta-se que os parâmetros "a" e "b" dos modelos gerados dependem dos materiais genéticos, os quais possuem características distintas, principalmente relacionados à arquitetura da planta. De fato, diversos autores citados por Maddonni \& Otegui (1996) relatam que as diferenças nos parâmetros "a" e "b" se devem aos efeitos da cultivar, altura da planta, número e ângulo da folha e IAF. Além desses fatores, a data de semeadura, a população de plantas, e o manejo de irrigação podem também contribuir para a modificação da estrutura do dossel da planta.

As informações geradas pelos modelos fornecem apenas uma primeira aproximação, devido à possibilidade de uma grande quantidade de outros fatores que podem afetar os resultados. Neste estudo, os modelos foram utilizados para estimar a interceptação máxima da lâmina, e também as quantidades $\left(\mathrm{t} \mathrm{ha} \mathrm{a}^{-1}\right)$ de nitrogênio $\mathrm{e}$ potássio retidos nas folhas da cultura do milho. A inclusão de outras variáveis implicaria numa maior complexidade do modelo, sem ganho na estimativa do valor relativo ao atributo de interesse (lâmina máxima de calda armazenada nas folhas).

A metodologia foi adequada, em razão da estrutura de coleta de amostra utilizada, na qual a planta foi dividida em alturas de coleta, através de coletores presos ao colmo e "piscinas" montadas nas mesmas alturas, envolvendo uma área maior de captação. As outras metodologias propostas nos trabalhos citados anteriormente não apresentam a mesma adequação. A metodologia utilizada por esses autores para quantificar PI, INT e Ec apresenta variações e procedimentos questionáveis, tais como: sistemas de coleta de água na planta somente de um lado do colmo; coletores circulares e calhas metálicas dispostas entre as linhas de plantio (podendo ou não receber água conforme sua posição debaixo das folhas); e determinação da lâmina de água interceptada feita por diferença de massa da planta, antes e após a aplicação de água, considerando a massa constitutiva de água da planta vizinha.

Cabe ressaltar que a metodologia utilizada neste estudo pode não ser a mais adequada para outros casos. No entanto, com base nos trabalhos encontrados na literatura, procurou-se reduzir os problemas e falhas encontradas na forma de coleta de água na planta, pelo aprimoramento e somatório das formas de coleta de água utilizadas 
nos trabalhos, almejando obter informações mais representativas da quantidade de água e de produtos retidos pela cultura de milho.

\subsection{CONSIDERAÇÕES FINAIS}

\subsubsection{Resumo dos resultados}

As interceptação média de água nas folhas de milho, para a fase de 4 folhas, foi aproximadamente $1,87 \%$.

Para o estádio de desenvolvimento de 8 folhas, os valores médios de PI, Ec e INT na altura de coleta $0,00 \mathrm{~m}$, foram $85,57,7,87$ e $6,56 \%$, respectivamente. E para a altura de $0,25 \mathrm{~m}$ foram $88,31,6,12$ e 5,57\% para PI, Ec e INT, respectivamente;

Para a fase de 12 folhas os valores médios de Ec, INT e PI para a altura de coleta $0,00 \mathrm{~m}$ foram $12,24,7,21$ e $80,55 \%$, respectivamente. Para a altura de coleta de 0,50 foram 12,35, 6,21 e 81,53\% para Ec, INT e PI. Finalmente para altura de coleta de 1,40 m os valores médios de Ec, INT e PI foram 13,22, 3,61 e 83,17\%, respectivamente;

O aumento da altura de coleta de água em relação ao nível do solo proporcionou um aumento na estimativa dos valores de precipitação interna e escoamento pelo colmo, e redução nos valores de interceptação foliar;

Verificou-se para época (E2) que as duas alturas amostradas na planta promoveram diferenças significativas para as variáveis INT, Ec e PI, entretanto, não influenciaram nos valores de concentrações de fertilizantes;

No estádio fenológico de 12 folhas, as três alturas estudadas na planta promoveram diferenças significativas somente para a variável INT, não verificando esse efeito para PI e Ec. As concentrações de fertilizantes foram afetadas pelas alturas (3 terços) estudadas na planta. 
As quantidades médias de fertilizantes interceptados pelo dossel da cultura de milho, na época (E1), foram de $1,56 \%(\mathrm{~N})$ e $1,95 \%\left(\mathrm{~K}_{2} \mathrm{O}\right)$, e na época (E2) de $14,3 \%(\mathrm{~N})$ e $12,3 \%\left(\mathrm{~K}_{2} \mathrm{O}\right)$. Na época $(\mathrm{E} 3)$ as quantidades médias de fertilizantes interceptados pelo dossel da cultura foram de $19,0 \%(\mathrm{~N})$ e $19,4 \%\left(\mathrm{~K}_{2} \mathrm{O}\right)$.

\subsubsection{Considerações gerais sobre a metodologia utilizada}

A metodologia utilizada na determinação da lâmina de água interceptada pela cultura do milho na fase de desenvolvimento de 4 folhas (E1), em que se baseou na diferença de massa das plantas, antes e após a aplicação de água, apresentou limitações. $\mathrm{Na}$ fase jovem da cultura, necessitou de cuidados especiais, visando a manter intacta a lâmina retida nas folhas, evitando perdas de água durante a coleta de plantas, logo após a passagem do pivô. Tal metodologia torna-se, praticamente, inviável para plantas de milho com IAF superiores a 3, pois parte da lâmina de água retida na folhagem poderá ser perdida durante a sua coleta e o seu transporte.

Para as épocas de coleta de 8 folhas (E2) e 12 folhas (E3), a metodologia utilizada com coletores presos em diferentes alturas na planta mostrou-se eficiente. Os problemas freqüentemente encontrados se relacionaram em manter uma vedação perfeita dos coletores ao colmo do milho, solucionados após testes consecutivos feitos anteriormente. Os reservatórios de lona plástica "piscinas" mostraram-se eficientes para a determinação da precipitação interna. Por possuir uma área de coleta maior, quando comparada com coletores circulares ou calhas dispostos na base das plantas, utilizados em outros trabalhos citados, eliminam os problemas do coletor estar em posição desfavorável (sob as folhas), podendo não receber a precipitação. Toda a água aplicada sobre a área da "piscina" foi determinada, tanto pela captação dos coletores presos ao colmo como pelas "piscinas". O excesso da lâmina interceptada escoou pelo colmo, devido ao efeito "funil" das folhas de milho, ou transbordou, chegando às "piscinas".

As alturas de coletas utilizadas nos sistemas de captação da lâmina aplicada foram representativas para as épocas (E2) e (E3). 
A metodologia utilizada nas épocas (E2) e (E3) foi eficiente, no entanto, visando ao aprimoramento do sistema de coleta, algumas modificações podem contribuir de forma expressiva na obtenção dos resultados, tais como: (número maior de repetição; inclusão de novas alturas de coleta na planta; novos coletores e "piscinas" com tamanhos e materiais diferentes, outras cultivares e espaçamentos). 


\section{CONCLUSÕES}

A fertigação com o propósito de aplicar nitrogênio e potássio via foliar na cultura do milho não é recomendada, pois, os valores médios interceptados de nitrogênio e potássio foram 1,56 e $19,4 \%$ para 4 e 12 folhas, respectivamente.

A lâmina média interceptada pelo dossel das plantas pode ser estimada em função do desenvolvimento relativo da cultura, ou pelo índice de área foliar.

As quantidades médias de nitrogênio e potássio interceptadas pelo dossel das plantas, visando à aplicação foliar na cultura do milho, podem ser estimadas, através dos modelos ajustados, em função do desenvolvimento relativo da cultura, ou pelo índice de área foliar. 
ANEXO A : VARIAÇÃO DO POTENCIAL MÁTRICO 
Data

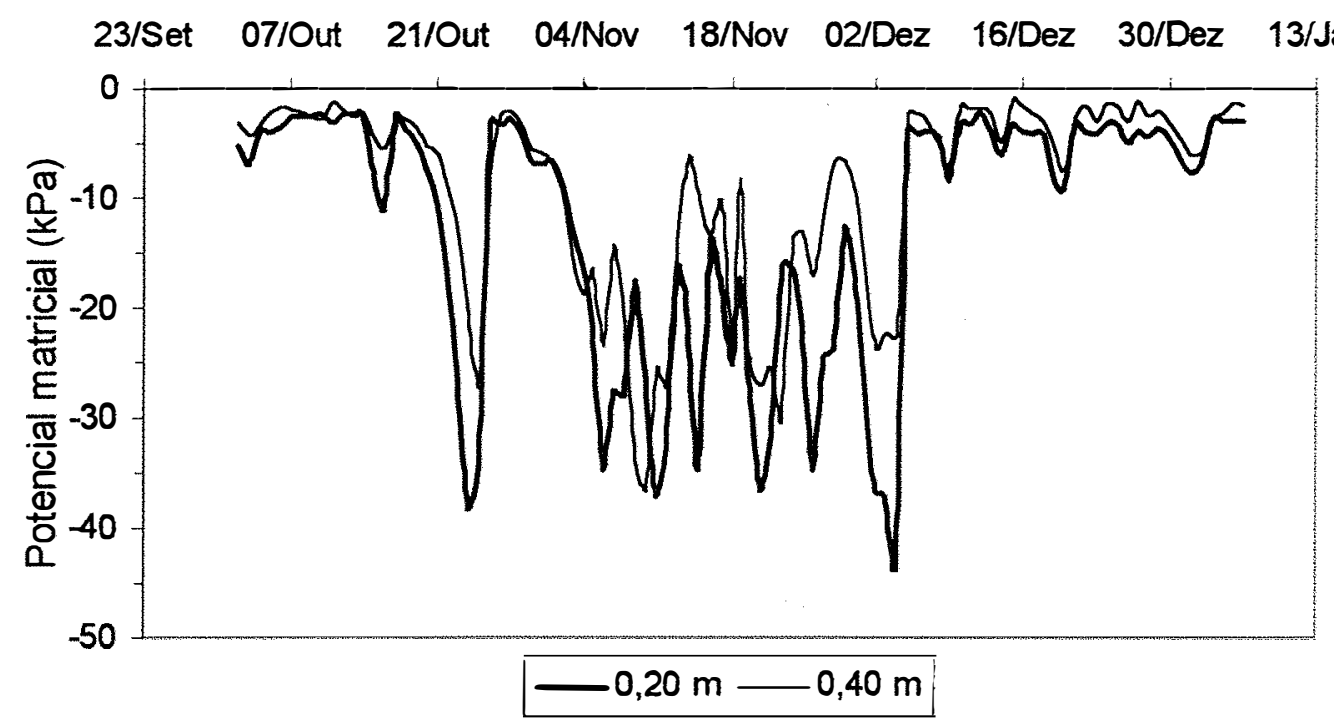

Figura 25 - Variação do potencial mátrico da água nas profundidades de 0,20 e 0,40m no solo cultivado com a cultura do milho. 
ANEXO B : VARIÁ VEIS CLIMÁTICAS 
Tabela 21. Variáveis climáticas observadas às 6:30h.

\begin{tabular}{ccccc}
\hline Data & $\begin{array}{c}\text { Temperatura } \\
\left({ }^{\circ} \mathrm{C}\right)\end{array}$ & $\begin{array}{c}\text { UR } \\
(\%)\end{array}$ & $\begin{array}{c}\text { Vento } \\
\left(\mathrm{m} \mathrm{s}^{-1}\right)\end{array}$ & $\begin{array}{c}\text { Radiação } \\
\left(\mathrm{W} \mathrm{m}^{-2}\right)\end{array}$ \\
\hline $02 / 10 / 98$ & 14,8 & 95 & 0,00 & 4,67 \\
$03 / 10 / 98$ & 14,7 & 96 & 0,00 & 10,23 \\
$04 / 10 / 98$ & 16,1 & 94 & 0,06 & 7,33 \\
$20 / 10 / 98$ & 15,7 & 95 & 0,64 & 21,85 \\
$21 / 10 / 98$ & 15,6 & 92 & 0,08 & 29,09 \\
$22 / 10 / 98$ & 15,0 & 95 & 0,00 & 30,31 \\
$08 / 11 / 98$ & 18,5 & 95 & 0,92 & 46,69 \\
$09 / 11 / 98$ & 17,6 & 92 & 0,87 & 31,51 \\
$13 / 11 / 98$ & 15,4 & 98 & 0,00 & 31,54
\end{tabular}

Fonte: Depto. Ciências Exatas - ESALQ/USP (Posto meteorológico) 
ANEXO C : LÂMINAS COLETADAS 
Tabela 22. Valores médios de lâminas (mm) obtidos nas 3 linhas de coletores, referentes às épocas $(\mathrm{E} 1),(\mathrm{E} 2) \mathrm{e}(\mathrm{E} 3)$.

\begin{tabular}{c|ccc|ccc|ccc}
\hline Coletores & \multicolumn{3}{|c|}{ (E1) } & \multicolumn{3}{c|}{ (E2) } & \multicolumn{3}{c}{ (E3) } \\
& $02 /$ out & $03 /$ out & $04 /$ out & $20 /$ out & $21 /$ out & $22 /$ out & $08 /$ nov & $09 /$ nov & 13/nov \\
\hline 1 & 2,7 & 2,2 & 2,9 & 2,3 & 2,7 & 3,3 & 2,8 & 2,7 & 3,3 \\
2 & 3,0 & 3,4 & 3,0 & 3,2 & 3,8 & 3,2 & 3,3 & 2,6 & 3,0 \\
3 & 2,8 & 3,0 & 3,3 & 2,8 & 2,7 & 3,6 & 2,8 & 2,5 & 3,5 \\
4 & 3,1 & 3,8 & 2,7 & 2,6 & 2,8 & 3,2 & 2,6 & 2,8 & 2,8 \\
5 & 3,4 & 3,2 & 3,6 & 3,4 & 3,2 & 2,8 & 2,7 & 2,5 & 3,3 \\
6 & 3,3 & 3,2 & 2,7 & 2,6 & 3,2 & 2,7 & 3,8 & 2,8 & 3,3 \\
7 & 3,2 & 3,3 & 2,7 & 3,8 & 3,3 & 3,1 & 2,7 & 3,3 & 2,7 \\
8 & 3,3 & 3,0 & 3,8 & 2,8 & 3,0 & 2,8 & 3,8 & 2,7 & 2,6 \\
9 & 3,3 & 2,7 & 2,7 & 3,2 & 3,0 & 3,0 & 3,0 & 3,2 & 3,1 \\
10 & 2,7 & 3,0 & 2,3 & 3,3 & 2,3 & 2,6 & 2,9 & 2,2 & 2,5 \\
\hline Média & 3,07 & 3,07 & 2,97 & 3,01 & 3,00 & 3,03 & 2,98 & 2,97 & 3,01 \\
Desvio Pad. & 0,7 & 0,7 & 0,7 & 0,7 & 0,7 & 0,5 & 0,7 & 0,7 & 0,7 \\
CV(\%) & 23,4 & 23,5 & 24,4 & 24,1 & 23,8 & 15,1 & 22,1 & 24,5 & 23,5 \\
CUC(\%) & 82,7 & 82,6 & 82,2 & 82,2 & 82,7 & 81,5 & 81,7 & 83,4 & 83,1 \\
\hline
\end{tabular}


ANEXO D : CONCENTRAÇÕES E QUANTIDADES DE FERTILIZANTES 
Tabela 23. Valores de índice de área foliar (IAF), desenvolvimento relativo da cultura $(D r)$, Interceptação foliar da lâmina $(\mathbb{N N T})$, concentração de fertilizante $\left(\mathrm{C}_{\mathrm{N}}\right.$, $\mathrm{C}_{\mathrm{K}}$ e $\mathrm{C}_{\mathrm{NK}}$ ) para as épocas (E1), (E2) e (E3), correspondentes aos estádios fenológicos de 4,8 e 12 folhas.

\begin{tabular}{|c|c|c|c|c|c|c|c|c|c|}
\hline & IAF & Dr & $\begin{array}{l}\text { INT } \\
\mathrm{mm}\end{array}$ & $\begin{array}{c}\mathrm{Cn} \\
\mathrm{g} \mathrm{L}^{-1}\end{array}$ & $\begin{array}{c}\mathrm{Ck} \\
\mathrm{g} \mathrm{L}^{-1} \\
\end{array}$ & $\begin{array}{l}\text { Cnk } \\
\mathrm{g} \mathrm{L}^{-1}\end{array}$ & $\begin{array}{l}\text { QN } \\
\text { t ha }^{-1}\end{array}$ & $\begin{array}{c}\mathrm{QK} \\
\text { t ha }^{-1}\end{array}$ & $\begin{array}{l}\text { QNK } \\
\mathrm{t} \mathrm{ha}^{-1}\end{array}$ \\
\hline \multirow{9}{*}{ E 1} & 0,30 & 0,39 & 0,059 & 0,196 & 0,240 & 0,849 & 0,00012 & 0,00014 & 0,00050 \\
\hline & 0,24 & 0,39 & 0,047 & 0,195 & 0,239 & 0,849 & 0,00009 & 0,00011 & 0,00040 \\
\hline & 0,25 & 0,39 & 0,049 & 0,195 & 0,241 & 0,849 & 0,00010 & 0,00012 & 0,00041 \\
\hline & 0,27 & 0,39 & 0,053 & 0,197 & 0,247 & 0,873 & 0,00010 & 0,00013 & 0,00046 \\
\hline & 0,27 & 0,39 & 0,053 & 0,196 & 0,248 & 0,873 & 0,00010 & 0,00013 & 0,00046 \\
\hline & 0,29 & 0,39 & 0,058 & 0,200 & 0,246 & 0,873 & 0,00012 & 0,00014 & 0,00051 \\
\hline & 0,31 & 0,39 & 0,060 & 0,192 & 0,248 & 0,897 & 0,00011 & 0,00015 & 0,00053 \\
\hline & 0,33 & 0,39 & 0,065 & 0,198 & 0,249 & 0,897 & 0,00013 & 0,00016 & 0,00059 \\
\hline & 0,31 & 0,39 & 0,059 & 0,191 & 0,246 & 0,897 & 0,00011 & 0,00015 & 0,00053 \\
\hline \multirow{9}{*}{ E 2} & 2,98 & 0,64 & 0,380 & 0,552 & 0,249 & 1,273 & 00210 & 0,00095 & 0,00484 \\
\hline & 2,97 & 0,64 & 0,360 & 0,555 & 0,250 & 1,259 & 0,00200 & 0,00090 & 0,00453 \\
\hline & 3,01 & 0,64 & 0,360 & 0,534 & 0,243 & 1,306 & 0,00192 & 0,00088 & 0,00470 \\
\hline & 3,13 & 0,64 & 0,380 & 0,529 & 0,243 & 1,301 & 00201 & 0,00092 & 0,00494 \\
\hline & 2,93 & 0,64 & 0,320 & 0,540 & 0,202 & 1,260 & 0,00173 & 0,00065 & 0,00403 \\
\hline & 3,33 & 0,64 & 0,420 & 0,541 & 0,212 & 1,264 & 0,00227 & 0,00089 & 0,00531 \\
\hline & 3,22 & 0,64 & 0,330 & 0,555 & 0,249 & 1,259 & 0,00183 & 0,00082 & 0,00415 \\
\hline & 3,43 & 0,64 & 0,350 & 0,534 & 0,243 & 1,260 & 0,00187 & 0,00085 & 0,00441 \\
\hline & 3,15 & 0,64 & 0,430 & 0,541 & 0,212 & 1,301 & 0,00233 & 0,00091 & 0,00559 \\
\hline \multirow{9}{*}{ E3 } & 4,29 & 0,94 & 0,520 & 0,724 & 0,186 & 0,631 & 0,00377 & 0,00096 & 0,00328 \\
\hline & 4,99 & 0,94 & 0,720 & 0,732 & 0,189 & 0,625 & 0,00527 & 0,00136 & 0,00450 \\
\hline & 5,06 & 0,94 & 0,580 & 0,728 & 0,180 & 0,613 & 0,00422 & 0,00104 & 0,00356 \\
\hline & 4,20 & 0,94 & 0,350 & 0,730 & 0,192 & 0,629 & 0,00256 & 0,00067 & 0,00220 \\
\hline & 4,37 & 0,94 & 0,480 & 0,737 & 0,188 & 0,612 & 0,00354 & 0,00090 & 0,00294 \\
\hline & 4,26 & 0,94 & 0,570 & 0,742 & 0,184 & 0,616 & 0,00423 & 0,00105 & 0,00351 \\
\hline & 3,99 & 0,94 & 0,480 & 0,736 & 0,194 & 0,624 & 0,00353 & 0,00093 & 0,00300 \\
\hline & 4,05 & 0,94 & 0,470 & 0,736 & 0,191 & 0,625 & 0,00346 & 0,00090 & 0,00294 \\
\hline & 3,91 & 0,94 & 0,490 & 0,738 & 0,188 & 0,625 & 0,00362 & 0,00092 & 0,00306 \\
\hline
\end{tabular}


Tabela 24. Caldas formuladas em laboratório com os valores de diluição (ml), condutividade elétrica da água de diluição $\left(\mathrm{dS} . \mathrm{m}^{-1}\right)$, razão de diluição, concentração da calda observada $\left(\mathrm{g} \mathrm{L}^{-1}\right)$, concentração da calda estimada $\left(\mathrm{g} \mathrm{L}^{-1}\right)$, quantidade de fertilizante diluídos $(\mathrm{kg})$ por volume no tanque $(\mathrm{L}) \mathrm{e}$ diferenças entre calda de laboratório (1) e a formulada em campo (2).

\begin{tabular}{|c|c|c|c|c|c|c|c|c|}
\hline $\begin{array}{c}\text { Diluição } \\
(\mathrm{ml})\end{array}$ & $\begin{array}{c}\text { CEa diluição } \\
\left(\mathrm{dS} \mathrm{m} \mathrm{m}^{-1}\right)\end{array}$ & $\begin{array}{c}\text { Razão } \\
\text { diluição }\end{array}$ & $\begin{array}{c}\text { Conc. Diluição } \\
\left(\mathrm{g} \mathrm{L}^{-1}\right)\end{array}$ & $\begin{array}{l}\text { Conc. } \\
\text { Estimada } \\
\left(\mathrm{g} \mathrm{L}^{-1}\right) \\
\end{array}$ & $\begin{array}{l}\text { kg Fertiliz/ vol (L) } \\
\mathrm{CEw}\left(\mathrm{dS} \mathrm{m}{ }^{-1}\right) \\
\end{array}$ & $\begin{array}{c}\text { CE Calda } \\
\left(\mathrm{dS} \cdot \mathrm{m}^{-1}\right) \\
(1)\end{array}$ & $\begin{array}{c}\text { CE Bomba } \\
\left(\mathrm{dS} \cdot \mathrm{m}^{-1}\right) \\
(2)\end{array}$ & $\begin{array}{l}\text { variação \% } \\
\text { entre } 1 \text { e } 2 \\
\end{array}$ \\
\hline $\begin{array}{l}790 \\
830 \\
790 \\
\end{array}$ & $\begin{array}{r}4,200 \\
4,100 \\
4,200 \\
\end{array}$ & $\begin{array}{l}0,0127 \\
0,0120 \\
\mathbf{0 , 0 1 2 7} \\
\end{array}$ & $\begin{array}{l}0,867 \\
0,825 \\
0,867 \\
\end{array}$ & 0,873 & $\begin{array}{c}65 \mathrm{SA} / 21,7 \mathrm{KCl}-375 \mathrm{~L} \\
4,200\end{array}$ & 193,00 & 190,70 & \\
\hline $\begin{array}{l}350 \\
400 \\
397 \\
\end{array}$ & $\begin{array}{l}1,070 \\
0,960 \\
0,967\end{array}$ & $\begin{array}{l}0,0143 \\
0,0125 \\
\mathbf{0 , 0 1 2 6} \\
\end{array}$ & $\begin{array}{l}0,270 \\
0,237 \\
\mathbf{0 , 2 3 9} \\
\end{array}$ & 0,245 & $\begin{array}{c}12 \mathrm{KCl}-375 \mathrm{~L} \\
0,966 \\
\end{array}$ & 46,50 & 42,60 & 8,387 \\
\hline $\begin{array}{l}300 \\
330 \\
289 \\
\end{array}$ & $\begin{array}{l}1,780 \\
1,640 \\
1,839 \\
\end{array}$ & $\begin{array}{l}0,0133 \\
0,0121 \\
\mathbf{0 , 0 1 3 8} \\
\end{array}$ & $\begin{array}{l}0,184 \\
0,167 \\
0,191 \\
\end{array}$ & 0,195 & $\begin{array}{c}35 \text { SA - 500 L } \\
1,837 \\
\end{array}$ & 73,30 & 68,40 & 6,685 \\
\hline $\begin{array}{l}142 \\
152 \\
140 \\
\end{array}$ & $\begin{array}{l}0,755 \\
0,724 \\
0,767 \\
\end{array}$ & $\begin{array}{l}0,0141 \\
0,0132 \\
\mathbf{0 , 0 1 4 3} \\
\end{array}$ & $\begin{array}{l}0,184 \\
0,172 \\
\mathbf{0 , 1 8 7} \\
\end{array}$ & 0,188 & $\begin{array}{c}8,3 \mathrm{KCI}-375 \mathrm{~L} \\
0,765 \\
\end{array}$ & 33,50 & 31,30 & 6,567 \\
\hline $\begin{array}{l}160 \\
170 \\
148 \\
\end{array}$ & $\begin{array}{l}5,100 \\
4,800 \\
5,490 \\
\end{array}$ & $\begin{array}{l}0,0125 \\
0,0118 \\
\mathbf{0 , 0 1 3 5} \\
\end{array}$ & $\begin{array}{l}0,658 \\
0,620 \\
\mathbf{0 , 7 1 1} \\
\end{array}$ & 0,734 & $\begin{array}{c}100 S A-375 L \\
5,483 \\
\end{array}$ & 190,60 & 189,20 & 0,735 \\
\hline $\begin{array}{l}150 \\
200 \\
156 \\
\end{array}$ & $\begin{array}{l}4,500 \\
3,500 \\
4,380 \\
\end{array}$ & $\begin{array}{l}0,0133 \\
0,0100 \\
0,0128 \\
\end{array}$ & $\begin{array}{l}0,620 \\
0,466 \\
\mathbf{0 , 5 9 6} \\
\end{array}$ & 0,621 & $\begin{array}{c}100 \mathrm{SA} / 8,3 \mathrm{KCl}-630 \mathrm{~L} \\
4,383 \\
\end{array}$ & 159,60 & $168, \infty$ & $-5,263$ \\
\hline $\begin{array}{l}140 \\
160 \\
148 \\
\end{array}$ & $\begin{array}{l}1,000 \\
0,850 \\
0,940 \\
\end{array}$ & $\begin{array}{l}0,0143 \\
0,0125 \\
\mathbf{0 , 0 1 3 5} \\
\end{array}$ & $\begin{array}{l}0,238 \\
0,209 \\
0,226 \\
\end{array}$ & 0,233 & $\begin{array}{c}12 \mathrm{KCl}-425 \mathrm{~L} \\
0,940 \\
\end{array}$ & 49,30 & 46,30 & 6,085 \\
\hline $\begin{array}{l}150 \\
155 \\
150\end{array}$ & $\begin{array}{l}6,420 \\
6,250 \\
6,420\end{array}$ & $\begin{array}{l}0,0133 \\
0,0129 \\
\mathbf{0 , 0 1 3 3}\end{array}$ & $\begin{array}{l}1,283 \\
1,242 \\
1,283\end{array}$ & 1,283 & $\begin{array}{c}130 \mathrm{SA} / 21,7 \mathrm{KCl}-376 \mathrm{~L} \\
6,393\end{array}$ & 302,40 & 320,80 & $-6,085$ \\
\hline $\begin{array}{l}142 \\
147 \\
144\end{array}$ & $\begin{array}{l}3,850 \\
3,800 \\
3,940\end{array}$ & $\begin{array}{l}0,0141 \\
0,0136 \\
\mathbf{0 , 0 1 3 9}\end{array}$ & $\begin{array}{l}0,518 \\
0,501 \\
\mathbf{0 , 5 1 1}\end{array}$ & 0,522 & $\begin{array}{c}70 \mathrm{SA}-375 \mathrm{~L} \\
3,948 \\
\end{array}$ & 152,20 & 163,40 & $-7,359$ \\
\hline
\end{tabular}


Tabela 25. Valores médios de concentrações de fertilizantes obtidos em função das condutividades elétricas observadas nos coletores próximos ao solo e acima do dossel, estimadas através das equações ajustadas, para as três caldas formuladas na época $\mathrm{E} 1$ (4 folhas).

\begin{tabular}{c|c|c|c}
\hline \multicolumn{3}{|c}{ Concentração de produto na calda $\left(\mathrm{g} \mathrm{L}^{-1}\right)$} \\
\hline $02-04$ /out & $\begin{array}{c}\text { Cn=0,1252CEw - 0,0346 } \\
35 \text { (SA) }\end{array}$ & $\begin{array}{c}\text { Ck=0,3162CEw - 0,0605 } \\
12(\mathrm{KCl}) * *\end{array}$ & $\begin{array}{c}\text { Cnk=0,2397CEw - 0,1333 } \\
65 \text { (SA) / 21,7 (KCl) }\end{array}$ \\
\hline Volume de diluição & 500 litros & 375 litros & 375 litros \\
\hline P1- Coletor & 0,195 & 0,240 & 0,849 \\
P2- Coletor & 0,197 & 0,247 & 0,873 \\
P3- Coletor & 0,194 & 0,247 & 0,897 \\
P1- Calda (acima) & 0,195 & 0,240 & 0,849 \\
P2- Calda (acima) & 0,197 & 0,247 & 0,873 \\
P3- Calda (acima) & 0,194 & 0,248 & 0,897 \\
\hline
\end{tabular}

* $\quad 35 \mathrm{~kg} \mathrm{SA}=$ Sulfato de amônio / ha

** $\quad 12 \mathrm{KCl}=$ Cloreto de potássio / ha

*** $\quad 65 \mathrm{~kg} \mathrm{SA}$ e $21,7 \mathrm{~kg} \mathrm{KCl} / \mathrm{ha}$ 
Tabela 26. Valores médios de concentrações de fertilizantes obtidos em função das condutividades elétricas observadas nas alturas de coleta 0,00 e $0,25 \mathrm{~m}$ e acima do dossel, estimadas através das equações ajustadas para as três caldas formuladas na época E2 (8 folhas).

\begin{tabular}{c|c|c|c}
\hline \multicolumn{3}{c}{ Concentração de produto na calda $(\mathrm{g} \mathrm{L})^{-1}$} \\
\hline $20-22$ /out & $\begin{array}{c}\text { Cn=0,1545CEw - 0,0868 } \\
70 \mathrm{~kg}(\mathrm{SA})^{*}\end{array}$ & $\begin{array}{c}\mathrm{Ck}=0,3162 \mathrm{CEw}-0,0609 \\
12 \mathrm{~kg}(\mathrm{KCl}) * *\end{array}$ & $\begin{array}{c}\text { Cnk=0,2214CEw - 0,1382 } \\
130 \mathrm{~kg}(\mathrm{SA}) / 21,7(\mathrm{KCl})^{* * *}\end{array}$ \\
\hline Volume de diluição & 375 litros & 425 litros & 375 litros \\
\hline P1-0 & 0,534 & 0,249 & 1,273 \\
P1-25 & 0,537 & 0,250 & 1,259 \\
\hline P2-0 & 0,515 & 0,243 & 1,306 \\
P2-25 & 0,510 & 0,243 & 1,301 \\
\hline P3-0 & 0,521 & 0,202 & 1,260 \\
P3 - 25 & 0,522 & 0,212 & 1,264 \\
\hline P1- Calda (acima) & 0,539 & 0,277 & 1,308 \\
P2- Calda (acima) & 0,536 & 0,258 & 1,314 \\
P3- Calda (acima) & 0,539 & 0,268 & 1,303 \\
\hline
\end{tabular}

* $\quad 70 \mathrm{~kg} \mathrm{SA}=$ Sulfato de amônio / ha

** $\quad 12 \mathrm{~kg} \mathrm{KCl}=$ Cloreto de potássio / ha

$130 \mathrm{~kg} \mathrm{SA}$ e $21,7 \mathrm{~kg} \mathrm{KCl} / \mathrm{ha}$ 
Tabela 27. Valores médios de concentrações de fertilizantes obtidos em função das condutividades elétricas observadas nas alturas de coleta 0,00 e 0,50 e 1,40m e acima do dossel, estimadas através das equações ajustadas para as três caldas formuladas na época E3 (12 folhas).

\begin{tabular}{|c|c|c|c|}
\hline \multicolumn{4}{|c|}{ Concentração de produto na calda $\left(\mathrm{g} \mathrm{L}^{-1}\right)$} \\
\hline $08-13 /$ nov & $\begin{array}{c}\mathrm{Ck}=0,3263 \mathrm{CEW}-0,0618 \\
8,3(\mathrm{KCl})^{*} \\
\end{array}$ & $\begin{array}{c}\mathrm{Cn}=0,1514 \mathrm{CEw}-0,0963 \\
100(\mathrm{SA})^{* *}\end{array}$ & $\begin{array}{l}\mathrm{Cnk}=0,1623 \mathrm{CEw}-0,089 \\
100(\mathrm{SA}) / 8,3(\mathrm{KCl})^{* * *}\end{array}$ \\
\hline Volume de diluição & 375 litros & 375 litros & 530 litros \\
\hline$P 1-0,00$ & 0,186 & 0,724 & 0,631 \\
\hline $\mathrm{P} 1-0,50$ & 0,189 & 0,732 & 0,625 \\
\hline $\mathrm{P} 1-1,40$ & 0,180 & 0,728 & 0,613 \\
\hline $\mathrm{P} 1-0,00$ & 0,192 & 0,730 & 0,629 \\
\hline $\mathrm{P} 1-0,50$ & 0,188 & 0,737 & 0,612 \\
\hline $\mathrm{P} 1-1,40$ & 0,184 & 0,742 & 0,616 \\
\hline $\mathrm{P} 1-0,00$ & 0,191 & 0,736 & 0,624 \\
\hline$P 1-0,50$ & 0,191 & 0,736 & 0,625 \\
\hline $\mathrm{P} 1-1,40$ & 0,188 & 0,738 & 0,625 \\
\hline P1-Calda (acima) & 0,193 & 0,741 & 0,636 \\
\hline P2-Calda (acima) & 0,195 & 0,744 & 0,630 \\
\hline P3-Calda (acima) & 0,192 & 0,745 & 0,648 \\
\hline
\end{tabular}

* $\quad 100 \mathrm{~kg} \mathrm{SA}=$ Sulfato de amônio / ha

** $\quad 8,3 \mathrm{~kg} \mathrm{KCl}=$ Cloreto de potássio / ha

*** $\quad 100 \mathrm{~kg} \mathrm{SA}$ e $8,3 \mathrm{~kg} \mathrm{KCl} / \mathrm{ha}$ 


\section{REFERÊNCIAS BIBLIOGRÁFICAS}

ALVES, V. M. V.; FRANÇA, G.E. de; RESENDE, M.; COELHO, A.M. Aplicação de fertilizantes nitrogenados via irrigação. Sete Lagoas: EMBRAPA/CNPMS, 1992. v.6, p.32-34. (Relatório Técnico Anual do Centro Nacional de Milho e Sorgo 19881991).

ASSOCIAÇÃO BRASILEIRA DE NORMAS TÉCNICAS. Sistemas de irrigação por aspersão pivô-central-caracterização de desempenho/método de ensaio: projeto de norma 12:02.08-005. Rio de Janeiro, 1985. 9p.

BASANTA, M. DEL VALLE. Modelo para estimativa do volume máximo de calda visando a aplicação foliar de produtos químicos na cultura de milho (Zea mays L.). Piracicaba, 1999. 65p. Dissertação (Mestrado) - Escola Superior de Agricultura Luiz de Queiroz, Universidade de São Paulo.

BERNARDO, S. Manual de irrigação. 5 ed., Viçosa: Imprensa Universitária, UFV, 1989. 596p.

BEZERRA, F.M.L. Coeficientes de cultura e efeitos de déficits hídricos nos diferentes estádios fenológicos sobre a produção da batata (Solanum tuberosum, L.) . Piracicaba, 1995. 131p. Tese (Doutorado) - Escola superior de Agricultura "Luiz de Queiroz", Universidade de São Paulo. 
BOARETTO, A. E.; CRUZ, A. P.; LUZ, P.H. de C. Adubo líquido: produção e uso no Brasil. Campinas: Fundação Cargill, 1991. 100p.

BÜLL, L.T. Nutrição mineral do milho. In: BÜLL, L.T.; CANTARELLA, H. (Ed.) Cultura do milho: fatores que afetam a produtividade. Piracicaba: POTAFOS, 1993. p.63-145.

CANTARELLA, H. Calagem e adubação do milho. In: BÜLL, L.; CANTARELLA, H. Cultura do milho: fatores que a afetam a produtividade. Piracicaba: POTAFOS, 1993. p.147-96.

CASTILHO, C.P. G.; TEIXEIRA FILHO, J.; LULU, J. Relação entre o índice de área foliar e a interceptação de chuvas na cultura de cana de açúcar. (compact disc). In: CONGRESSO BRASILEIRO DE ENGENHARIA AGRÍCOLA, 29, Fortaleza, 2000. Fortaleza: Sociedade Brasileira de Engenharia Agrícola, 2000.

CASTROA, F. de; FETCHERA, N. Three dimensional model of the interception of light by a canopy. Agricultural and Forest Meteorology, v.90, p.215-233, 1998.

CHRISTIANSEN, J. E. Irrigation by sprinkling. Berkeley: University of California, California Agricultural Experiment Station, 1942. 124p. (Bulletin, 670).

COELHO, A.M.; FRANÇA, G.E. de; BAHIA FILHO, A.F.C. Nutrição e adubação do milho forrageiro. In: EMBRAPA / CNPMS. Sete Lagoas, MG. Milho para silagem: tecnologias, sistemas e custo de produção, 1991. p.29-33. (EMBRAPA/CNPMS. Circular Técnica, 14).

COElHO, A. M.; FRANÇA, G. E.; BAHIA FILHO, A. F. C.; GUEDES, G. A. A. Doses e métodos de aplicação de fertilizantes nitrogenados na cultura do milho sob irrigação. Revista Brasileira de Ciência do Solo, v.16, p.61-67, 1992. 
COELHO, A. M. Fertigação In: COSTA, E. F. da; VIEIRA, R. F.; VIANA, P. A. (Ed.) Quimigação: aplicação de produtos químicos e biológicos via irrigação. Brasília: EMBRAPA-SPI, 1994. cap.8, p.201-28.

COELHO, A. M.; FRANÇA, G. E. de. Seja o doutor de seu milho. Arquivo do Agronômo POTAFOS, nํำ . Set. 1995. p.1-24.

CONTE, M. L.; LEOPOLDO, P.R. Estimativa da retenção de água de chuva pela cultura do milho. Engenharia Agrícola, v.10, n.1, p.47-55, 1986.

COSTA, E. F.; FRANÇA, G. E.; ALVES, V. M. C. Aplicação de fertilizante via água de irrigação. Informe Agropecuário, v.12, n.139, p.63-8, 1986.

COSTA, E.F.; BRITO, R.A.L.; SILVA, E.M. da. Cálculos e Manejo da Quimigação nos Sistemas Pressurizados. In: COSTA, E. F. da; VIEIRA, R. F.; VIANA, P. A. (Ed.). Quimigação: aplicação de produtos químicos e biológicos via irrigação. Brasília: EMBRAPA-SPI, 1994. cap.7, p. 183-200.

CRUZ, O.C. da Distribuição horizontal do inseticida chlorpyrifos aplicado via pivô central em cultura de milho (Zea mays L.) e sua retenção no dossel das plantas. Lavras, 1997. 54p. Dissertação (Mestrado) - Universidade Federal de Lavras.

COTRIM, C E. Análise de uniformidade de aplicação de água em sistemas de irrigação do tipo pivô central de baixa pressão. Viçosa, 1988. 114p. Dissertação (Mestrado) Universidade Federal de Viçosa.

DOORENBOS, J.; KASSAM, A.H. Efeito da água no rendimento das culturas. Trad. de H. R Gueyi,.A.A.de Sousa, F.A.V. Damasceno e J.F. de Medeiros. Campina Grande: UFPB, 1994. 306p. (Estudos da FAO: Irrigação e Drenagem, 33). 
DOURADO NETO, D.; FANCELLI, A.L. Quimigação. In: DOURADO NETO, D.; FANCELLI, A.L. (Ed.) Tecnologia da produção do feijão irrigado. Piracicaba: Publique, 1997. p.65-80.

DOURADO NETO, D.; FANCELLI, A.L. Quimigação na cultura do feijão. In: FOLEGATTI, M.V. (Coord.) (Ed.) Fertirrigação: citrus, flores, hortaliças. Guaíba: Agropecuária, 1999. p.393-432.

DOWLER, C.C. Herbicides and irrigaton technology - present and future. In: NATIONAL SYMPOSIUM ON CHEMIGATION, 3, Tifton, 1985. Proceedings. Tifton: Rural Development Center, 1985. p. 58-67.

DOWLER, C. C.; GASCHO, G. J.; YOUNG, JR. Chemical potential for corn production. West Lafayette: Purdue University, Cooperative Extension Service, 1989. 8p.

ECK, H.U. Effects of water deficits on yield, yield components and water use efficiency of irrigation corn. Agronomy Journal, v.75, p.1035-1040, 1986.

FANCELLI, A. L.; DOURADO NETO, D. Cultura do milho: aspectos fisiológicos e manejo de água. In: SEMINÁRIO SOBRE FISIOLOGIA DA PRODUÇÃO E MANEJO DE ÁGUA E DE NUTRIENTES NA CULTURA DO MILHO DE ALTA PRODUTIVIDADE, 1996. Piracicaba, Informações Agronômicas. POTAFOS, n.73, p.1-4, 1996.

FAQUIN, V. Exigências nutricionais e funções dos nutrientes. In: FAQUIN, V. Nutrição mineral de plantas. Lavras: ESAL, FAEPE, 1994. cap.3, p.87-176. 
FLENET, F.; KINIRY, J.R.; BOARD, J.E.; WESTGATE, M.E.; REICOSKY,D.C. Fow spacing effects on light extinction coefficients of corn, sorghum, soybean, and sunflower. Agronomy Journal. v.88, p. 185-190, 1996.

FOLEGATTI, M.V.; PAZ, V.P.; MUNDIN, P.M. Interceptação foliar da lâmina de irrigação na cultura do milho sob aspersão convencional. In: CONGRESSO BRASILEIRO DE ENGENHARIA AGRÍCOLA, 27, Poços de Caldas, 1998. Anais. Poços de Caldas: SBEA, 1998. v.2, p.19-21.

FRIZZONE, J. A.; BOTREL, T. A.; DOURADO NETO, D. Aplicação de fertilizantes via água de irrigação. Piracicaba: ESALQ, 1994. 35p. (Série Didática, 8).

GASCHO, G.J.; HOOK, J.E. Development of a nitrogen fertigation program for corn on sand soil. In: NATIONAL SYMPOSIUM ON CHEMIGATION, 3, Tifton, 1985. Proceedings. Tifton: University of Georgia, 1885. p.42-50.

HAYNES, J. L. Ground rainfall under vegetative canopy of crops. Journal of the American Society of Agronomy. v.32, p.176-184, 1940.

HEERMANN, D. F.; HEIN, P. R. Performance characteristics of self-propelled centerpivot sprinkler irrigation system. Transactions of the ASAE, v.11, n.1, p.11-15, 1968.

HERGET, G. W.; REUSS, J. O. Sprinkler aplication of $\mathrm{P}$ and $\mathrm{Zn}$ fertilizers. Agronomy Journal, v.68, p.5-8, 1976.

HERNANDEZ, F. B. T. Potencialidades da fertirrigação. In: SIMPÓSIO BRASILEIRO SOBRE FERTILIZANTES FLUÍDOS, 1993, Piracicaba. Anais. Piracicaba: ESALQ/CENA, POTAFOS, 1993. p.199-210. 
HICKEY, M. G.; BEAN, B. W.; LEON NEW, L. Fertigation: Fertilizer Application with Center Pivots. In: LEON NEW, L; HICKEY, M. G.; BEAN, B. W. Chemigation: Workbook. Texas: Texas Agricultural Extension Service., 1990. cap. IV, p.15-23.

JANDEL TBLCURVE. TableCurve. Curve fitting software. Jandel Scientific, Corte Madera, CA. 1992.

LEOPOLDO, P. R.; SOUSA, A.P. e TUACEK FILHO, S. Interceptação da água de chuva em cultura da cana de açúcar. Brasil Açucareiro, v.98, n.6, p.9-16, 1981.

LIMA, L. A.; ALVES, D. R. B. Avaliação da uniformidade de distribuição de água de microaspersores e microdifusores. In: CONGRESSO BRASILEIRO DE ENGENHARIA AGRÍCOLA, 18, Campinas, 1994. Resumos. Campinas, SBEA, 1994. p.116.

MADDONNI, G.A; OTEGUI, M.E. Leaf area, light interception, and crop development in maize. Field Crops Research, v.48, p.81-87. 1996.

MALAVOlta, E. O potássio e a planta. 4 ed. Piracicaba: Instituto da Potassa e do Fosfato: Instituto Internacional da Potassa, 1982. 92p.

MEDINA SAN JUAN, J. A. Riego por gotejo: teoria e prática. Madrid: Mundi Prensa, 1988. $461 \mathrm{p}$.

MENDONÇA, F. C. Adubação nitrogenada na cultura do milho aplicada por um sistema de aspersão em linha. Piracicaba, 1994. 60p. Dissertação (Mestrado) - Escola Superior de Agricultura Luiz de Queiroz, Universidade de São Paulo. 
MONTEIRO, M. A. R.; COSTA, E. F. da, GHEIY, H. R.; PINTO, J. M. Níveis de nitrogênio e lâminas de irrigação no rendimento do milho verde. Pesquisa Agropecuária Brasileira, v.24, n.6, p.741-749, jun, 1989.

MUSECK, J.T.; DUSER, D.A Irrigated corn yield response to water. Transactions of the ASAE, v.23, p.1040-92, 1980.

PAPADOPOULOS, I. Fertirrigação: Situação atual e perspectivas para o futuro In: FOLEGATTI, M.V. (Coord.) (Ed.) Fertirrigação: citrus, flores, hortaliças. Guaíba: Agropecuária, 1999. p.11-84.

PARKIN, T.B.; CODLING, E.E. Rainfall distribution under a corn canopy: implications for managing agrochemicals. Agronomy Journal, v.82, p.1166 - 1169, 1990.

PESSOA, P.C.S. Desempenho de um sistema pivô central equipado com diferentes configurações de emissores ao longo do ciclo de uma cultura de milho. Piracicaba, 1994. 95p. Dissertação (Mestrado) - Escola Superior de Agricultura Luiz de Queiroz, Universidade de São Paulo.

PIZARRO, F. C. Riegos localizados de alta frequência. Madrid: Mundi Prensa, 1987. $461 \mathrm{p}$.

QUINN, N.W.; LAFLEN, J.M. Caracteristics of Raindrop Throughfall Under Corn Canopy. Transactions of the ASAE, v.26, n.5, p.1445-1450, 1983.

RAIJ, B. van. Potássio. In: RAIJ, B. van. Fertilidade do solo e adubação. Piracicaba: CERES; POTAFOS, 1991. cap.11, p.205-218. 
RAIJ, B. van,; CANTARELLA, H. Milho para grãos e silagem. In: RAIJ, B. van; CANTARELLA, H.; QUAGGIO. Jr. ; FURLANI, AM.C. (Ed.). Recomendações de adubação e calagem para o Estado de São Paulo. Campinas: Instituto Agronômico, 1996. p.56-59. (IAC. Boletim Técnico, 100).

RAMOS, M. M.; MANTOVANI, E. C. Sistemas de irrigação e seus componentes. In: COSTA, E. F., VIEIRA, R. F., VIANA, P. A., Quimigação: aplicação de produtos químicos e biológicos via irrigação. Brasília: EMBRAPA-SPI, 1994. cap.2, p. 41-84.

REHM, G. W.; Wiesse, R. A Effect of method of nitrogen application on corn (Zea mays. L.) grow of irrigated sandy soils. Soil Science Society America Journal, v.39, p.1217-1220, 1975.

REHM, G. W.; YOUNG, J. R.; SUMNER, D. R. Fertigation of corn in the easten Great Plains. In: NATIONAL SYMPOSIUM ON CHEMIGATION, 2, Nebraska, 1982. Proceedings. Nebraska: Northeast Experiment Station - University of Nebraska. 1982. p.4-10

RESENDE, M., FRANÇA, G. E., ALVES, V. M. C. Cultura do milho irrigado. In: BÜlL, L., CANTARELlA, H. Cultura do milho: Fatores que a afetam a produtividade. Piracicaba: POTAFOS, 1990. p.237-48.

REZENDE, R. Desempenho de um sistema de irrigação pivô central quanto a uniformidade e eficiência de aplicação de água, abaixo e acima da superficie do solo. Piracicaba, 1992. 86p. Dissertação (Mestrado) - Escola Superior de Agricultura Luiz de Queiroz, Universidade de São Paulo.

RHOADS, F. M.; STANLEY JÚNIOR, R. L. Response of three corn two hybrids to low levels of soil moisture tension in the plow layer. Agronomy Journal, v.65, p.315-318, 1973. 
RHOADS, F. M.; STANLEY J., R. L. Fertilizer scheduling, yield, and nutrient uptake of irrigated corn. Agronomy Journal, v.73, p.971-975, 1981.

ROBERTS, J., POTTS, B. J. Chemigation: A partnership worth exploring. Irrigaton Journal. v.41, p.16-29, 1991.

SANTOS, N. C. dos. Uniformidade de distribuição e eficiência potencial de aplicação de água em um sistema de irrigação do tipo pivô central, em condições de cerrado. Viçosa, 1988, 80p. Dissertação (Mestrado) - Universidade Federal de Viçosa.

SHANI, M. La fertilizaticíon combinada con el riego. Tel Aviv: Ministerio de Agricultura, 1981. 36p.

SILVA, C.L. da ; RAMOS, M.M. ; FERREIRA, P.A. et al. Medição e simulação da interceptação foliar de água na cultura do milho. Pesquisa Agropecuária Brasileira, v.29, n.11, p.1735-1741, nov. 1994.

SILVEIRA, R. C.; HILLS, D. J.; YATES, W. E. Insecticide oil distribution pattern from a linear move spray head. Transactions of the ASAE, v.30, n.2, p.438-441, 1987.

STEINER, J. L.; KANEMASU, E. T.; CLARK, R. N. Spray losses and partitioning of water under a center pivot sprinkler system. Transactions of the ASAE, v.26, n.4, p.1128-1134, 1983.

STONE, K.C.; STANSELL, J.R.; YOUNG, J.R. Insecticide distribution through an irrigated corn canopy. Transactions of the ASAE, v.37, n.1, p.135-138, 1994.

THREADGILL, E. D. Current status and future of chemigation. In: NATIONAL SYMPOSIUM ON CHEMIGATION, 3, Tifton; 1985. Proceedings. Tifton, Rural Development Center, 1985. p.1-12. 
THREADGILL, E. D. Advances in irrigation, fertigation and chemigation. In: EXPERT CONSUTATION ON FERTIGATION/CHEMIGATION, Cairo, 1991. Proceedings. Rome, FAO, 1991a. p.136-155.

THREADGILL, E. D. Chemigation and plant protection. In: EXPERT CONSUTATION ON FERTIGATION/CHEMigation, Cairo, 1991. Proceedings. Rome, FAO, 1991b. p.30-44.

TRPANI, N.; HALL, A.J.; SADRAS, V.O.; VIELLA, F. Ontogenic changes in radiation use efficiency of sunflower ( Helianthus annuus L.) crops. Field Crops Research, v.29; p.301-316, 1992.

VASCONCELOS, C. A.; SANTOS, H. L.; FRANÇA, G. E. O potássio na cultura do milho. In: YAMADA, T. (Ed.) Potássio na agricultura brasileira. Piracicaba: Instituto da Potassa e do Fosfato, Instituto Internacional da Potassa, 1982. p.437-48.

VIANA, P. A.; COSTA, E. F. da. Controle da lagarta do cartucho, Spodoptera frugiperda (Lepdoptera: Noctuidae) em milho, com inseticidas aplicados via irrigação por aspersão. In: CONGR̀ESSO BRASILEIRO DE ENTOMOLOGIA, 12, 1989, Belo Horizonte, Resumos. Belo Horizonte, 1989. p.295.

VIANA, P. A.; COSTA, E. F. da. Controle da lagarta dó elasmo, Elasmopalpus lignosellus, com inseticidas aplicados via irrigação por aspersão, na cultura do milho. Sete Lagoas: EMBRAPA/CNPMS, 1992. p.45. (Relatório Técnico Anual do Centro Nacional de Milho e Sorgo 1988-1991).

VIEIRA, D.B. Avaliação da interceptação hidrológica e o efeito da vinhaça em cana de açúcar. Limeira, 1982. 124 p. Tese (Livre Docência) - Faculdade de Engenharia de Limeira, UNICAMP, 1982. 
VIEIRA, R. F. Introdução a quimigação. In: COSTA, E. F. , VIEIRA, R. F., VIANA, P.A. Quimigação: aplicação de produtos químicos e biológicos via irrigação. Brasília: EMBRAPA-SPI, 1994. cap.1, p.13-40.

VITTI, G. C.; BOARETTO, A. E; PENTEADO, S. R. Fontes de fertilizantes e fertirrigação. In: SIMPÓSIO BRASILEIRO SOBRE FERTILIZANTES FLUÍDOS, Piracicaba, 1993. Anais. Piracicaba, ESALQ/CENA, POTAFOS, 1993, p.233-256.

YAMADA, T. Adubação nitrogenada do milho. Como melhorar a eficiência? Informações Agronômicas. POTAFOS. n.71, p. 1-3, set, 1995.

YOUNG, J. R. Suppression of fall armyworm populations by incorporation of insecticides into irrigation water. Florida Entomologist, v.63, p.447-450, 1980.

WAUCHOPE, R.D.; SUMNER, H.R.; DOWLER, C.C. A Measurement of the total mass of spray and irrigation mixtures intercepted by small whole plants. Weed Technology. v.11, p.466-472, 1997.

ZANINI, J. R. Hidráuliça da fertirrigação por gotejamento utilizando tanque de derivação de fluxo e bomba injetora. Piracicaba, 1987. 103p. Tese ( Doutorado) Escola Superior de Agricultura Luiz de Queiroz, Universidade de São Paulo. 